Issue No. 23 | September 2017

Modelling the New Europe Interdisciplinary studies

\title{
On-line Journal
}

ISSN $2247-0514$ 
Issue no. $23 / 2017$

\section{Scientific Committee:}

- $\quad$ Prof. Dr. Gérard BOSSUAT, European Union Liaison Committee of Historians/ Professor Emeritus, Université de Cergy- Pontoise, France

- $\quad$ Prof. Dr.dr.h.c. Wichard WOYKE, Westfälische Wilhelms-Universität Munster, Germany

- $\quad$ Prof. Dr. Wilfried LOTH, President of the European Union Liaison Committee of Historians/Duisburg-Essen University, Germany

- $\quad$ Prof. Dr. phil. habil Michael GEHLER, Universität Hildesheim, Germany

- $\quad$ Prof. Dr. Dr.h.c. Reinhard MEYERS, Westfälische Wilhelms-Universität, Munster, Germany

- $\quad$ Prof. Dr. Dietmar WILSKE, Westfälische Wilhelms-Universität, Munster, Germany

- $\quad$ Prof. Dr. Sylvain SCHIRMANN, Director of the Institut d'études Politiques de Strasbourg, France

- $\quad$ Prof. Dr. Ioan HORGA, Institute for Euroregional Studies, University of Oradea

- $\quad$ Prof. Dr. George POEDE, Alexandru Ioan Cuza University of Iaşi, Iași

- $\quad$ Prof. Dr. Nicu GAVRILUTA, Alexandru Ioan Cuza University of Iaşi, Iaşi

- $\quad$ Prof. Dr. Vasile PUȘCAȘ, Faculty of European Studies, Babeş-Bolyai University, Cluj-Napoca

- $\quad$ Prof. Dr. Ovidiu PECICAN, Faculty of European Studies, Babeș-Bolyai University, Cluj-Napoca

- $\quad$ Prof. Dr. Marius JUCAN, Faculty of European Studies, Babeș-Bolyai University, Cluj-Napoca

- $\quad$ Prof. Dr. Gheorghe CLIVETI, “Alexandru Ioan Cuza” University, Iaşi

- $\quad$ Assoc. Prof. Dr. Adrian BASARABA, West University, Timişoara

- $\quad$ Assoc. Prof. Dr. Mircea MANIU, Faculty of European Studies, Babeș-Bolyai University, Cluj-Napoca

- $\quad$ Assoc. Prof. Dr. Simion COSTEA, Petru Maior University, Tg. Mureș

- $\quad$ Assoc. Prof. Dr. Liviu ȚîRĂU, Faculty of European Studies, Babeș-Bolyai University, Cluj-Napoca

- $\quad$ Assoc. Prof. Dr. Georgiana CICEO, Faculty of European Studies, Babeş-Bolyai University, Cluj-Napoca

- $\quad$ Assoc. Prof. Dr. Nicoleta RACOLTA-PAINA, Faculty of European Studies, Babeş-Bolyai University, Cluj-Napoca

- $\quad$ Assoc. Prof. Dr. Florin DUMA, Faculty of European Studies, Babeș-Bolyai University, Cluj-Napoca

- $\quad$ Assist. Prof. Dr. Mariano BARBATO (Professor DAAD), Babeș-Bolyai University, Cluj-Napoca

- $\quad$ Dr. Titus POENARU, Industry, Research and Energy (Policy Advisor), EP Brussels

- $\quad$ Dr. Gilda TRUICĂ, European Institute of Romania, Head of Communication Unit

\section{Editorial Staff}

Prof. Dr. Nicolae PĂUN: nicolae.paun@ubbcluj.ro

Assoc. Prof. Dr. Georgiana CICEO: gciceo@yahoo.com

Lect. Dr. Miruna Andreea BALOSIN: miruna.balosin@ubbcluj.ro

Lect. Dr. Adrian CORPĂDEAN: adi_corpadean@yahoo.com

Lect. Dr. Horațiu DAN: dan.horatiu.sorin@gmail.com

Lect. Dr. Delia FLANJA: delia.flanja@ubbcluj.ro

The On-line Journal Modelling the New Europe is opened to PhD students, young researchers and academic staff interested to promote researches and present different perspectives on the EU. The papers should provide an analysis of economic, social, cultural and political perspectives and developments on subjects concerning the European Union. 


\section{CONTENTS}

I. Ovidiu VAIDA: THE NEW CHALLENGES FOR THE EUROPEAN CENTRERIGHT AND CENTRE-LEFT AT THE BEGINNING OF NEW CENTURY

II. Robert ADAM: A POPULIST MOMENTUM IN THE EUROPEAN UNION?

III. Andrei AVRAM: FRAGMENTATION, FLUIDITY AND PERSONALIZATION: REMARKS ON SHIFTS IN THE PRO-EUROPEAN PARTY SPECTRUM IN THE REPUBLIC OF MOLDOVA AFTER 2014

IV. Horia-Alin LUPU: THE SOCIAL DEMOCRAT PARTY (PSD) IN ROMANIA WITHIN THE FRAMEWORK OF THE ROMANIAN AND EUROPEAN LEFT. THE PSD MANIFESTO FOR THE 2016 PARLIAMENTARIAN ELECTIONS

\section{VARIA}

V. Cristian POPA: THE EUROPEAN UNION - GETTING SPEEDS ON THE POLITICAL AGENDA, LOSING SPEED ON THE INTERNET

VI. Gergana RADOYKOVA: TOWARDS A MORE ACCOUNTABLE EU. MISSION POSSIBLE? 


\title{
THE NEW CHALLENGES FOR THE EUROPEAN CENTRE-RIGHT
}

AND

\section{CENTRE-LEFT AT THE BEGINNING OF NEW CENTURY}

\author{
Ovidiu VAIDA \\ Assistant Professor, $\mathrm{PhD}$ \\ Faculty of European Studies, \\ Babeş-Bolyai University Cluj-Napoca \\ ovidiuvaida@yahoo.com
}

DOI:10.24193/OJMNE.2017.23.01

\begin{abstract}
The political systems of the 1960s-1980s in Western Europe witnessed a pas de deux of two political blocks, the moderate left and the moderate right, which both collaborate in order to achieve stability, welfare state and European integration. As most of the successful stories, this one came eventually to an end: starting with the 1990s, the centre-left and centre-right parties were not able to replicate their previous results. Moreover, due to different circumstances in the recent years they could only achieve half of the percentages they gained decades ago. The aim of this article is to evaluate the shape of the centre-right and centre-left nowadays in Europe and also to find out whether such a consensus would be possible once more. Some explanation of why party systems changed dramatically in recent years will be provided.
\end{abstract}

Keywords: political consensus, centre-right, centre-left, elections.

\section{Introduction}

After 1945, a widely accepted consensus was the main feature of the political life in Western Europe. No matter if belonging to the left, right or centre, all political parties involved in government were committed to the same basic principles: smooth government, welfare state, social harmony, European integration.

Due to the recent history of Nazism and fascism and those days threat of communism, most parties tried to act closer to the centre, that is why most parties could be labelled as either of centre-left or centre-right, or moderate left and right.

The two main competitors were the Christian Democrats and the Social Democrats, with the Liberals coming as the third political family. 
Issue no. 23/2017

The main objectives, the welfare state, the European integration, European peace were achieved without heated debates. The best example for this is Italy, where Christian democrats were in power for more than four decades, being unaffected by the numerous changes in government, that is more than fifty between 1946 and 1993. The trade mark for Italian political system was the government based on broad alliances, formed by all sorts of parties, except the communists.

Despite several crises, economic problems, international difficulties, this system worked for almost five decades, with centre-left and centre-right parties alternating in power, sometimes even forming large coalitions. Starting with the 1990s, the (West) European political arena changed slowly. New parties emerged, the two main political groups started to loose votes and the old informal arrangement seemed to become obsolete. New leftist groups, Eurosceptic, populist, anti-system parties entered the party systems and in years were able to threaten governmental stability or even to fuel serious decisions, such as leaving the EU (Brexit).

The article tries to analyse what is the current status of the moderate left and moderate right in Western Europe. Also, since the 1950s-1980s are recalled as years of economic expansion, social peace, political consensus (with all the drawbacks), one research question is that the political circumstances could generate a somehow similar broad political alliance between the centre left and centre right, a new $21^{\text {st }}$ century consensus, as a base for political stability and political harmony.

First of all, an analysis of both the circumstances of 1960s-1980s, compared with the ones after 2000 is necessary. Secondly, the political environment, mainly the new party systems will be researched, to find out which are the new ideological and party developments; it is important to see where the parties are nowadays located, from an ideological point of view. Eventually, the current situation of (centre) left and right will come under scrutiny.

The literature is quite vast in what regards the left-right divide in politics. There are several attempts to measure the location of parties on a left-right scale, using different methods. All these analysis had been coded and integrated in databases, which all generates significant literature. Chief among them are the Chapel Hill expert surveys ${ }^{1}$ and the MARPOR (Manifesto Project) ${ }^{2}$. Based on expert surveys and manifesto coding, they were

\footnotetext{
${ }^{1}$ http://www.unc.edu/ gwmarks/data_pp.php [Accessed 22/08/17]

2 https://manifestoproject.wzb.eu/ [Accessed 22/08/17]
} 
followed by a lot of literature. The Chapel Hill surveys were described in Bakker et al. (2015) and also Polk et al. (2017). On the other hand, the Manifesto Project, since it is based on a longer endeavour, it could generate a longer list of articles and books. Dominant among them are the ones wrote by the MARPOR team, such as Budge et al. (2001), Klingemann et al. (2006) or Volkens et al. (2013). Other articles or works, based on these two sources or other ones will be highlighted in this article.

It must be underlined that while all these articles brought new facts and offered several explanation or description on the state of left and/or right, they somehow lack dynamism due to the fact that they are entirely based on program analysis or expert surveys. Most of them only analyse the position of a party on paper, without taking into consideration electoral campaigns, electoral results, the reaction of the party after some events, such as the British Conservatives or the Austrian Peoples Party, which moved to the right when it comes to policies/attitudes, while staying in the same position or even moving to the left in the recent years. ${ }^{3}$ In several cases, analysis showed that a party stayed in the same position on a left-right scale, or even moved in a direction, yet in reality, it had a quite different position.

Figure 1. Position of British Conservatives regarding European Integration

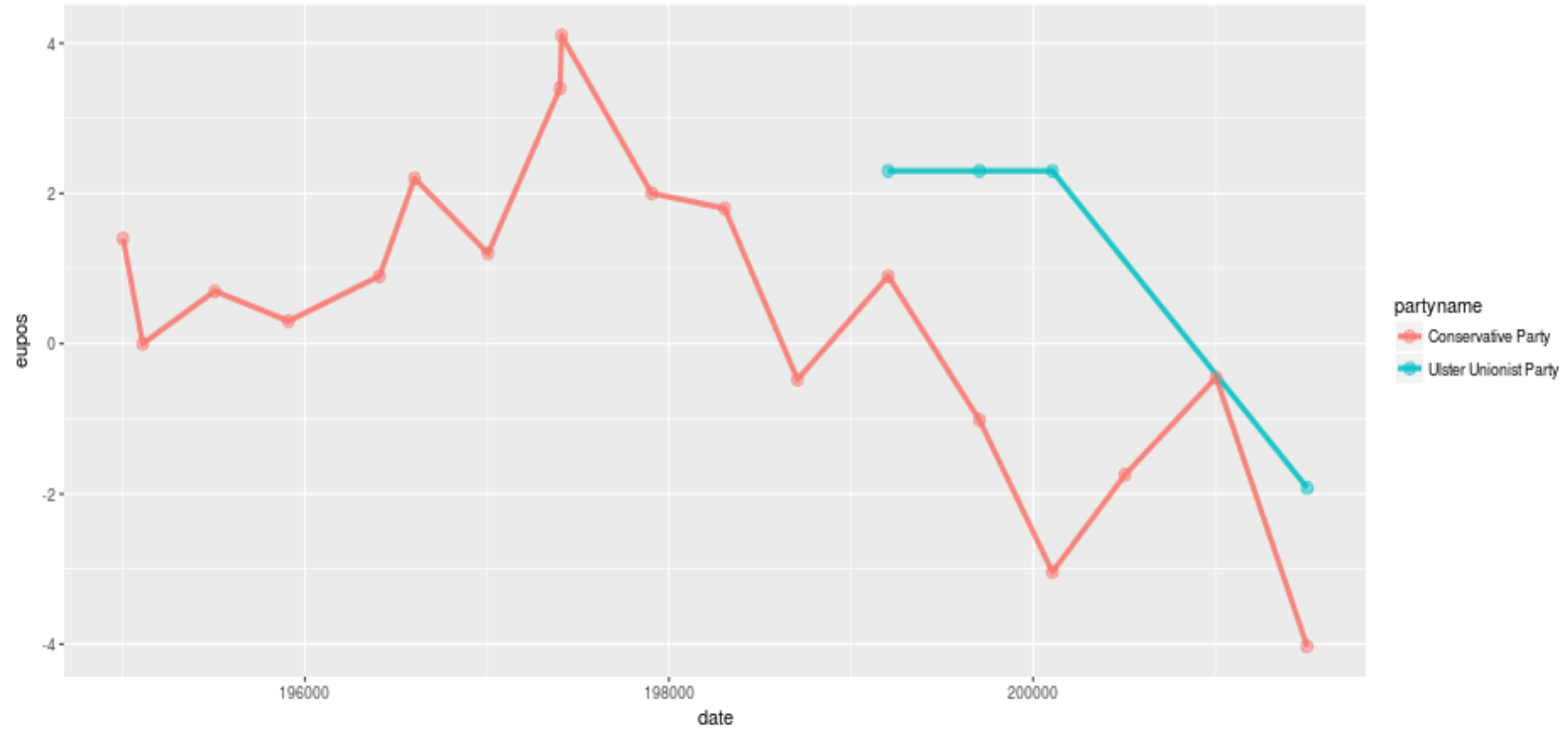

Source: https://visuals.manifesto-project.wzb.eu/mpdb-shiny/cmp dashboard/ [Accessed 22/08/17]

Note: The right is above level 0, while the left is located under level 0. It can be seen that since 2000, the Conservative party had a rather leftist position regarding European Integration that is a rather pro-EU position, fact which is denied by its recent position during Brexit.

${ }^{3}$ Briefly, the British Tories moved to the right partly due to the threat coming from UKIP 
Issue no. $23 / 2017$

The article discusses the party systems of the democratic countries of Western Europe after 1945, mainly the six which founded the European Union, plus Austria and the United Kingdom.

\section{The left and right during the 1950s-1980s}

After a devastating war, the political systems of the Western European countries changed dramatically. Several parties disappeared, so were entire party families. Fascism was outlawed, while communism was better regarded, due to the involvement of communist in the WWII battles. Conservative parties were punished for their closeness to fascism and there were the Christian-democrats who replaced them (Vaida, 2013). Economically, Europe witnessed what was called Les Trente Glorieuses that is almost three decades of economic boom, doubled by a generous welfare system.

The political life was as one would expect after a world war and all sort of extremist movements of the 1930s that is a rather calm one, without political shocks. The notable event of the 1950 s were the attempt to block the communist parties to enter the government. ${ }^{4}$ The main parties in the political system were the Christian-democrats and the Social-democratic parties. By being moderate right and moderate left, these parties were able to attract a huge number of votes, in some cases even $90 \%$ of them, together (see Germany 1965, 1969, 1972, Austria 1956, 1959, 1962, 1966, in the tables below).

Table 1. Electoral results in Germany, for the main competitors, 1949-1998

\begin{tabular}{|l|l|c|c|c|c|c|c|c|c|c|c|c|c|c|}
\hline & 1949 & 1953 & 1957 & 1961 & 1965 & 1969 & 1972 & 1976 & 1980 & 1983 & 1987 & 1990 & 1994 & 1998 \\
\hline CDU & 25,2 & 36,4 & 39,7 & 35,8 & 38,0 & 36,6 & 35,2 & 38,0 & 34,2 & 38,2 & 34,5 & 36,7 & 34,2 & 28,4 \\
\hline CSU & 5,8 & 8,8 & 10,5 & 9,6 & 9,6 & 9,5 & 9,7 & 10,6 & 10,3 & 10,6 & 9,8 & 7,1 & 7,3 & 6,7 \\
\hline SPD & 29,2 & 28,8 & 31,8 & 36,2 & 39,3 & 42,7 & 45,8 & 42,6 & 42,9 & 38,2 & 37,0 & 33,5 & 36,4 & 40,9 \\
\hline
\end{tabular}

Source: http://www.parties-and-elections.eu/germany2.html [Accessed 4/09/17] Note: The two main blocks received, combined, more than $80 \%$

Once with the 1980s, the political environment started to change, even so it worked not differently from the years before. Both the economy and the social-cultural areas were

\footnotetext{
${ }^{4}$ When speaking in this text about politics, political event, actions, etc, I mean only events involving parties and party systems, and not in the broader sense.
} 
Issue no. $23 / 2017$

affected by new incidents or processes, which all challenged the political parties.

First of all, there were the two energy (oil) crises of the 1973 and 1979. Secondly, the post-war economic boom came naturally to an end, and the welfare state based on Keynesianism required more and more money. The latter, fuelled by a combination of crises in several industrial areas, the ending of the Bretton Woods system led to rising unemployment and inflation. What most Western governments did was to slowly abandon Keynesianism and adopt monetary policies, that is to cut some welfare policies funds, to privatise some key economic areas (transportation, telecommunication, electric power) and in some cases to adopt genuine neo-liberal policies.

What was interesting is that even Social Democratic parties accepted these measures, in some cases being ready to adopt them, while in government.

On the other hand, it was the moment when the baby-boomers joined the political arena and in certain cases they were unhappy with the traditional parties and their offers. Some of these post-materialist voters were concerned with other issues than their parents, such as world peace, environment protection and others (see Inglehart, 1990).

Last but not least, there were the years when economy based on industrial production started to be replaced by the one centred on services. One effect was the decrease in importance of the Social Democratic parties, which started to constantly loose votes as of the 1990s.

It was also the moment the green parties emerged, and in the 1980s they already received enough votes to be accepted as stable competitors.

Table 2. Electoral results in the Netherlands, for the main competitors, 1948-1998

\begin{tabular}{|l|c|c|c|c|c|c|c|c|c|c|c|c|c|c|c|}
\hline & 1948 & 1952 & 1956 & 1959 & 1963 & 1967 & 1971 & 1972 & 1977 & 1981 & 1982 & 1986 & 1989 & 1994 & 1998 \\
\hline PvdA & 25,6 & 29,0 & 32,7 & 30,4 & 28,0 & 23,6 & 24,6 & 27,4 & 33,8 & 28,3 & 30,4 & 33,3 & 31,9 & 24,0 & 29,0 \\
\hline CDA & - & - & - & - & - & - & - & - & 31,9 & 30,8 & 29,3 & 34,6 & 35,3 & 22,2 & 18,4 \\
\hline KVP & 31,0 & 28,7 & 31,7 & 31,6 & 31,9 & 26,5 & 21,9 & 17,7 & - & - & - & - & - & - & - \\
\hline ARP & 13,2 & 11,3 & 9,9 & 9,4 & 8,7 & 9,9 & 8,6 & 8,8 & - & - & - & - & - & - & - \\
\hline CHU & 9,2 & 8,9 & 8,4 & 8,1 & 8,6 & 8,1 & 6,3 & 4,8 & - & - & - & - & - & - & - \\
\hline
\end{tabular}

Source: http://www.parties-and-elections.eu/netherlands2.html [Accessed 29/08/17]

Note: Until 1977, the three Christian Democratic parties acted separately, eventually they merged in 1977

Even the 1980s had turbulent moments, except the arrival of green parties, nothing important happened in the European political systems. Yet, even the two large camps still dominated (the centre right and centre left parties) it was easy to notice that they did not 
Issue no. $23 / 2017$

receive the same amounts of votes as one or two decades earlier. Besides the Greens, other parties, which even could not resist more than just few years begun to "steal" votes.

Table 3. Electoral results in Austria, for the main competitors, 1953-1999

\begin{tabular}{|c|c|c|c|c|c|c|c|c|c|c|c|c|c|c|c|}
\hline & 1953 & 1956 & 1959 & 1962 & 1966 & 1970 & 1971 & 1975 & 1979 & 1983 & 1986 & 1990 & 1994 & 1995 & 1999 \\
\hline SPÖ & 42,1 & 43,0 & 44,8 & 44,0 & 42,6 & 48,4 & 50,0 & 50.4 & 51,0 & 47,7 & 43,1 & 42,8 & 34,9 & 38,1 & 33,2 \\
\hline ÖVP & 41,3 & 46,0 & 44,2 & 45,4 & 48,4 & 44,7 & 43,1 & 43,0 & 41,9 & 43,2 & 41,3 & 32,1 & 27,7 & 28,3 & 26,9 \\
\hline
\end{tabular}

As mentioned earlier, the existence of communism in Eastern Europe influenced somehow the behaviour of parties and party systems in Western Europe, by making them to "freeze", yet not in the classical Rokkanian way, but by forcing the main parties to accommodate each other and inducing moderate politics.

That explains partially the fact the centre right parties accepted rather leftist policies, mainly connected to the welfare state and vice-versa, parties of the centre left did not reject the neoliberal policies of the 1980s.

Once communism collapsed in Eastern Europe and Soviet Union accepted the fact that it "lost" the cold war, there were several consequences. First of all, Western communist parties were severely affected by the disappearance of USSR, which used to be a model for them, not to mention the financial support that they received. Their electorate lost the interest in supporting a party unable to reshape its message and policies and with an obsolete model. Best examples are the communist in France and Italy, where after 1989 their parties hardly received more than $5 \%$, while in the 1970 s, even 1980 s, they were able to attract more than $20 \%$ of the votes, even an excellent $34,4 \%$ in Italy in $1976 .{ }^{5}$ It is important to note that the ex-communist voters did not necessarily joined other left-wing camps, such as Social Democrats, but moved towards other political groups, even populists (Davies, 2014) or extreme right Eurosceptic, such as the Front National in France (Miscoiu, 2005). Also, excommunist party members in unified Germany voted with Christian Democrats 1990 elections instead of more ideologically closer Social Democrats (Bösch, 2004).

On the other hand, curiously, those who lost from the fall of communism were the Christian democrats. While being pro-European, the Christian Democrats were fierce anticommunists and could attract many voters sharing the same belief. In other words, Christian

\footnotetext{
${ }^{5}$ In some cases communist parties virtually disappeared after 1989, see for instance Austria or the Netherlands, while in Sweden, Spain, Belgium or Luxembourg they survived, even in poor conditions.
} 
Democratic parties were able to keep these voters "captive" just based on the issue of anticommunism. Once this threat gone, Christian democrats had difficulties in mobilising voters only by using the fear of communism. Paradoxically, even they could be named winners of the Cold War as a party family, Christian Democrats started to loose votes right after $1989 .{ }^{6}$ In some cases, they voters chose the Green parties, while others moved to the right (Bösch, 2004). In fact, it was the moment when Christian democracy in general begun to move to the right (in Figure 2 it can be noticed the move to the right, after 1990, of Christian Democrats in four states, figures based on analysis of party programs, done under Manifesto Project - MARPOR)

Figure 2. The place on a left-right map of four Christian Democratic parties

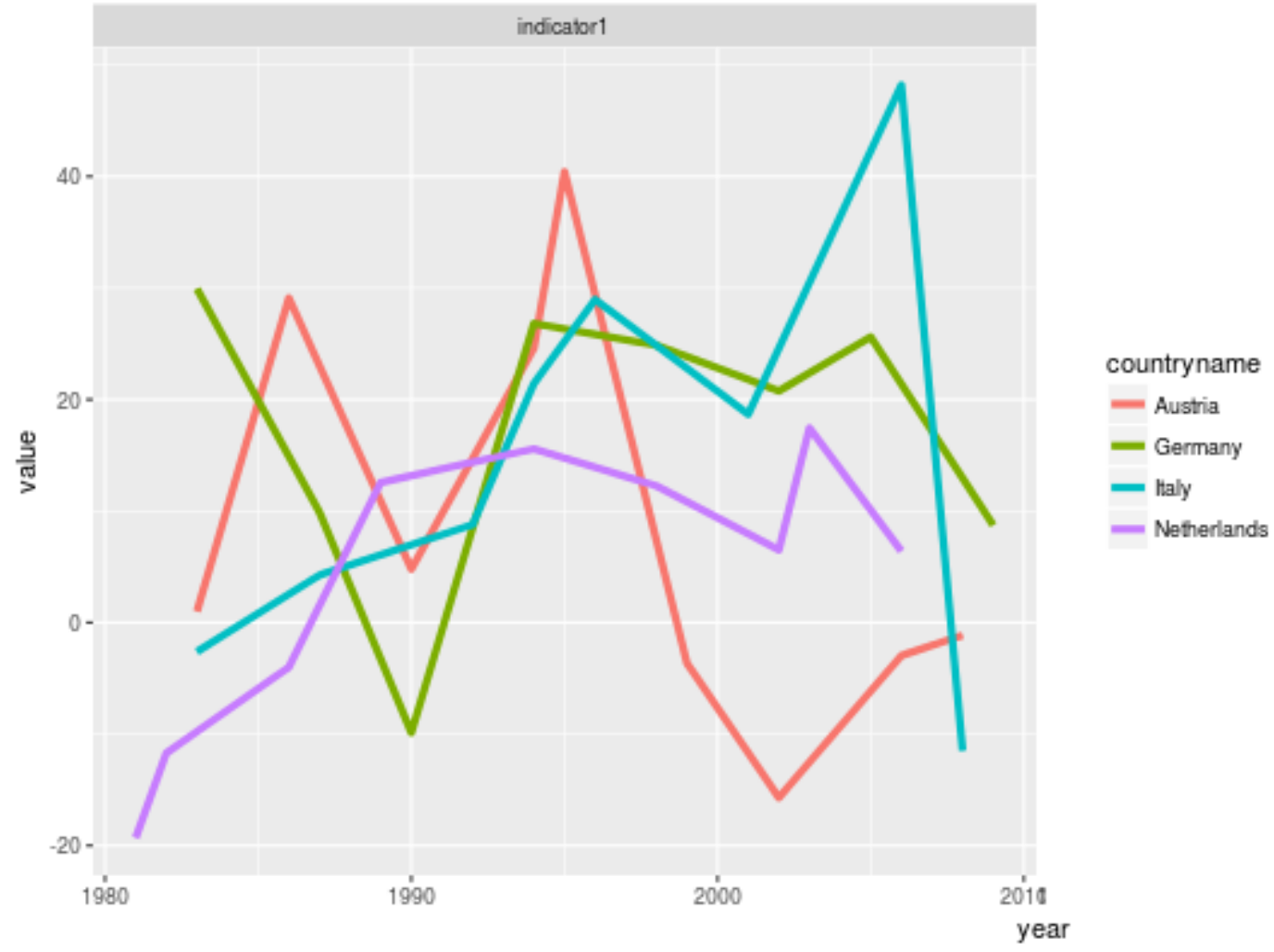

Source: https://visuals.manifesto-project.wzb.eu/mpdb-shiny/cmp_dashboard_countries/ [Accessed 22/08/17]

It could be an effect of growing secularization demobilization, the end of Cold War or other events, for the Christian Democrats, the fall of the Iron Curtain for the Communists, or

\footnotetext{
${ }^{6}$ In the Netherlands, CDA had the support of about $30 \%$ prior to 1989 , and $22 \%$ respectively $18 \%$ at the first two elections in the 1990 s. Those of Italian Christian Democrats are illustrious. In Austria, OVP received $43 \%$ and $41 \%$ during the 1980s, only to drop to $32 \%$ in 1990 , and $27 \%$ at the next elections.
} 
Issue no. $23 / 2017$

the decline of the industrial sector, for the Social Democrats, nevertheless it was in the 1990s when the traditional parties started slowly to lose votes. As mentioned, communists became rather marginal in the Western political arenas, while both the Social Democrats and the Christian Democrats embarked in their move to centre, respectively to the right. In the case of Social Democrats, it was what they called the Third way, while the Christian Democrats became more conservative, ideologically (Seiler 1993, Vaida 2014). The recipients were the green parties, the extreme right or left, all sorts of liberals or regionalist parties.

\section{The left and right during after the 1990s}

The new millennium brought new developments in the political systems of the European countries. Moderate left and the moderate right were further challenged by other political groups, some inexistent two decades ago. A list of what happened starting with the end of 1990s and the early 2000s could bring some suggestion about what was to come.

First of all, it was the process of European integration and EU enlargement that was in progress. In 2004, eight ex-communist countries joined the EU, two more in 2007 and Croatia in 2013. Not only was the end of a long European unification dream, but it also generated some difficulties. Briefly, it brought immigrants from the new member states, a process labelled mainly in the media under the phrase "Polish plumber" and which in some cases caused irritation. Secondly, the eight ex-communist states, less developed than their Western companions, needed and received European funds, which were lifted from old member states, the EU-15. Not to a large scale, but this also fuelled negative views regarding EU enlargement. Besides the new arrived states, "EU" and "Brussels" were blamed for the new situation by the new emerging party family, the Eurosceptics.

Already at the 1999 EP elections, the Eurosceptics received certain votes, yet under $5 \%$ and not disturbing the stable EPP/PES/LIB alliance. So did they in 2004, but it must be underlined that at this moment Front National and UKIP were able to gain 10\%, respectively $16 \%$.

At the beginning, the Eurosceptic parties were rather successful only at European parliament elections, where they gained more and more votes, yet, without affecting the decision making neither at European, nor at national level. That changed with the EP elections of 2009, where the Eurosceptics were able to win around 60 seats and able to form a stable and recognisable parliamentarian group, based on the UKIP MEPs. In 2007 a second Eurosceptic/far-right group formed, yet only to collapse a few month later. 
Issue no. $23 / 2017$

Even more important for a discussion on the European left and right was the formation of a new group (and in the same time, of a new trend in the European politics), the European Conservatives (officially, European Conservatives and Reformists). They came mainly from an EPP faction, unhappy with the moderate EPP and its support for the European Constitution, a heated topic of the 2004-2006 years (). They were able to form a group of about 60 MEPs (some MEPs came and left during the five years) and together with the Eurosceptics were able to induce a new tendency both at European and EP level, one opposing further integration and more Brussels.

It must be underlined that while in the 1990s, moderate left and right were still in good shape, historically one could point out the first years of the 2000s when the dynamics of the left and right started to change, to be more and more influenced by conservatism and Euroscepticism.

Besides the EU enlargement explanations, it must not forget the global economy difficulties. Years of economic growth ended in 2008, once with Lehman Brothers bank collapse. It was just the start of a four years economic recession, which affected the whole world economy. GDP growth was affected in almost every developed country, unemployment doubled in some cases, and the banking sector was heavily hit. Next came the Eurozone crisis, which affected already troubled Greece, Ireland, Spain and Portugal. The European Union helped these states by using several financial tools, such as bailout programs, loans, and all sorts of economic measures. As far as a left-right divide concern, these events had two main effects. On the one hand, at citizens' level, the general feeling was that taxpayers' money are spent to save countries which cannot follow basic financial rules. On the other hand, facing economic crises, almost all European governments, regardless their political colour, employed strict right wing measures, such as: financial austerity, budget consolidation, cutting spending (even of wages, especially in the public sector), increasing VAT. The short term effect of the all these were the fact that several citizens were affected by the crises and ready to punish those thought responsible. Obviously, they voted against parties in government when they could do so. The winners were not the left wing parties, as it would be logical when speaking about a government that imposed austerity, but the opposition parties, regardless of their ideology. Also it is worth to mention that that in several cases, there were the leftist parties that imposed austerity after 2009 and there were the rightwing parties those who won the next elections.

The combination of immigration, Euro and economy problems further facilitated the 
Issue no. $23 / 2017$

growth of Eurosceptic/right-wing parties. The progress they already experienced in 2009 and the next years continued with the 2014 European elections, yet under different circumstances. At this point, the Eurosceptic/populist/extreme right wing parties reached their best result at European level. They were able to win around 100 seats and strong enough to form even two parliamentary groups, the Europe of Freedom and Direct Democracy and the Europe of Nations and Freedom, the former centred around UKIP and the latter having Front National as a core. ${ }^{7}$

The other right-wing group, the ECR succeeded in coming third being the first party family to surpass the liberals for the first time since 1989. The conservatives received 70 seats, being able, together with the Eurosceptic groups, to push the EPP/SOC/LIB alliance under $65 \%$ of votes.

In fact the results of Eurosceptics did not come as a full surprise. Starting with the 2010 s, these parties acted electorally better and better, having the means to win elections or to jeopardize coalition formation. ${ }^{8}$

European countries were just recovering from the economic crises of 2008-2009 and new events challenged them, namely the European refugee crisis, starting with 2014, with a peak in 2015. Even though refugees arrive in Europe constantly and there are bodies and policies concerning them, the size of the new arrival waves took the EU by surprize. Most refugees came from countries involved in war, such as Syria or Iraq. The images with thousands of people trying to cross borders or sleeping in railway stations generated a lot of disputes. Obviously, the political arena was affected, at least in two aspects. First of all, some migrants were causing troubles after arriving, the media presenting the cases in a rather exaggerated manner. Secondly and most importantly, there were some terrorist attacks in Paris, London, Nice or Manchester, all being labelled as (Islamism terrorism). Even that most of these attacks were planned and executed by European born Islamist, it was common the belief that there might be some connection with the new arrived refugees. Needless to say that parties at the right, from conservatives to extreme-right ones, took position on this issue and demanded for firm action. Anyway, that further fuelled the rather anti-immigration, Eurosceptic discourse, which was in favour of the extreme-right wing parties.

Starting with 2015 there is a significant increase of votes for the far-right/Eurosceptic

\footnotetext{
${ }^{7}$ Some MEPs, such as those from Jobbik or other far-right parties were not accepted in these groups.

${ }^{8}$ M5S in Italy, election winner in 2013, PVV in the Netherlands, coming third then second, in 2017 and 2013 respectively, UKIP coming third in 2015, or in France Marine le Pen entered the second round of the presidential elections; not to mention Austria, where a far-right candidate almost won the presidential elections.
} 
Issue no. $23 / 2017$

parties in Europe. In 2016 a FPO member candidate was close to win the presidential elections in Austria, being defeated by a narrow margin. It must be mentioned that for the first time after WWII, there were no moderate left or moderate right wing candidate among those fighting for the presidential positions. Just month later, the same scenario took place in France, where Marine Le Pen, well-known leader of Front National, entered the second round of elections, being eventually defeated by Emmanuel Macron. Once again, there were no candidates of the left or the right in this presidential final round, a premiere, as in Austria. Also in 2017, in the Netherlands, the right-wing populist PVV arrived second in the parliamentarian elections, while in Germany, a party with a similar position, AfD, received almost $13 \%$, coming third after CDU/CSU and SPD. The same position was occupied by UKIP in 2013, with an astonishing 13\%. At this point, it should be mentioned that UKIP was already a strong competitor, since it achieved 26\% and the first place at the $2014 \mathrm{EP}$ elections, after $16 \%$ in 2009 . While not being very influential in the UK governmental area, and being able to be a voice only in Brussels, UKIP was instrumental in what was perceived as one of the most important blow for the EU, namely the Brexit.

\section{Conclusions}

The objective of the article was to analyse the shape of the moderate right and left in Europe in the recent years, as compared with the same political pair in the 1950s-1980s. For many decades, the two political groups overwhelmingly dominated the political systems of the Western European countries (see Table 1, 2, 3). In some cases, the two main parties received more than $90 \%$ at certain elections. Starting with the 1990 s, votes went to other parties, and the two political block could hardly find any solution. The result was that in two decades, they lost more than half of their votes combined (see Table 4, 5, 6).

Table 4. Electoral results in Germany, for the main competitors, 2002-2017

\begin{tabular}{|c|c|c|c|c|c|}
\hline & 2002 & 2005 & 2009 & 2013 & 2017 \\
\hline CDU & 29,5 & 27,8 & 27,3 & 34,1 & 26,8 \\
\hline CSU & 9,0 & 7,4 & 6,5 & 7,4 & 6,2 \\
\hline SPD & 38,5 & 34,2 & 23,0 & 25,7 & 20,5 \\
\hline
\end{tabular}

Source: http://www.parties-and-elections.eu/germany2.html [Accessed 17/09/2017]

A first and basic conclusion would be, at this point, that the centre right and the centre left are in poor condition, compared with their situation decades ago. 
Issue no. $23 / 2017$

What could explain the unfortunate situation of these party blocks? Obviously, they must be analyzed separately, even in certain cases their status was the result of their (non)cooperation. First of all, there are the parties of the left those who lost most of their influence and voters. Based on the classical cleavage of owners/workers, the socialist/socialdemocratic parties had a clear voter base that is the industrial workers in the first place, than any other worker category. Moreover, the left was voted by those less wealthy, those who wanted free education and health care and a protective pension system.

Table 5. Electoral results in Austria, for the main competitors, 2002-2013

\begin{tabular}{|l|l|l|l|l|}
\hline & 2002 & 2006 & 2008 & 2013 \\
\hline SPÖ & 36,5 & 35,3 & 29,3 & 26,8 \\
\hline ÖVP & 42,3 & 34,3 & 26,0 & 24,0 \\
\hline
\end{tabular}

To implement all these measures, which are the basics in a welfare state, the parties of the left needed several years, during which they were top electoral competitors (see the case of Austria, where Social Democrats received sometimes more than half of the votes, or of Germany or Great Britain). After the 1970s, the parties of the right not just accepted and imposed themselves such measures, but they did not challenged them, even in years of economic crises (except some minor adjustments). All these policies became part of the system. At this point, the Social Democrats ought to come with new proposals, regarding those less fortunate. What the parties of the left did was to move close to the centre, ideologically and adopt post-materialist views, socially. During the 1990s several parties of the left adopted close-to-the-centre positions, mainly in Great Britain (Third Way) and in Germany. Moreover, Social Democrats adopted positions regarding the environment, immigration or minorities of all types.

Table 6. Electoral results of the Social Democrats in Germany, in percentage, 1949-2017

\begin{tabular}{|c|c|c|c|c|c|c|c|c|c|c|}
\hline & 1949 & 1953 & 1957 & 1961 & 1965 & 1969 & 1972 & 1976 & 1980 & 1983 \\
\hline SPD & 29,2 & 28,8 & 31,8 & 36,2 & 39,3 & 42,7 & 45,8 & 42,6 & 42,9 & 38,2 \\
\hline & 1987 & 1990 & 1994 & 1998 & 2002 & 2005 & 2009 & 2013 & 2017 & \\
\hline SPD & 37,0 & 33,5 & 36,4 & 40,9 & 38,5 & 34,2 & 23,0 & 25,7 & 20,5 & \\
\hline
\end{tabular}


Issue no. $23 / 2017$

Another difficulty Social Democrats faced was the change in economy structure that is deindustrialisation. Industry, which once accounted for more than $40 \%$ of GDP output in the developed countries, is below 25\% nowadays. There are less and less industrial workers, not to mention the fact that the importance of trade unions, once part of the Social Democratic environment, vanished.

Table 7. Electoral results of the Social Democrats in Austria, in percentage, 1945-2013

\begin{tabular}{|c|c|c|c|c|c|c|c|c|c|c|c|c|c|c|}
\hline & 1945 & 1949 & 1953 & 1956 & 1959 & 1962 & 1966 & 1970 & 1971 & 1975 & 1979 & 1983 & 1986 & 1990 \\
\hline SPÖ & 44,6 & 38,7 & 42,1 & 43,0 & 44,8 & 44,0 & 42,6 & 48,4 & 50,0 & 50.4 & 51,0 & 47,7 & 43,1 & 42,8 \\
\hline & 1994 & 1995 & 1999 & 2002 & 2006 & 2008 & 2013 & & & & & & & \\
\hline SPÖ & 34,9 & 38,1 & 33,2 & 36,5 & 35,3 & 29,3 & 26,8 & & & & & & & \\
\hline
\end{tabular}

Source: http://www.parties-and-elections.eu/austria2.html [Accessed 22/08/17]

Facing the effects of globalization and of immigration, which in some cases brought job loses, the voters of the left moved in other direction, such as populist parties, even parties of the right. It must be noticed that from the two blocks that are researched in this article, the centre-left is in the worst position, compared with its situation in the 1970, for example (see Tables 6 and 7, with the particular situation of the 1972 elections in Germany or of the 1975 and 1979 in Austria).

On the other hand, the parties of the right had have a somehow better situation. Even they lost several votes and also political importance, in certain cases they still dominate the party systems in which they act (see Germany, Great Britain, and Luxemburg). Yet they had a price to pay. There were the Christian Democrats those who had to transform themselves, in some cases in a profound manner. They abandoned the centre economic policies adopting a rather neoliberal stance. They maintained most of welfare state policies, yet changing important parts of them: decrease of trade unions role, diminishing workers' rights and opening several economic areas. Except few parties, most Christian Democrats moved to the right, nowadays all these parties being labelled as 'Conservatives'.

Moreover, due to pressures coming from the right that is from populist/far-right parties the centre-right ones moved further to the right, abandoned their moderate position.

Tables $8 \mathrm{a}, 8 \mathrm{~b}$ and $8 \mathrm{c}$ are a good example of how the party systems look nowadays and what are the main ideologies or political offers for the voters. The tables are selected from Wolfram Nordsieck's web page, which is a data base with electoral results (http://www.parties-and-elections.eu/). The page also contains a political dictionary, for terms such as conservatism, national conservatism, euroscepticism, etc. The three tables display the 
Issue no. $23 / 2017$

electoral results and ideologies in recent elections in countries which decades ago had parties acting close to the centre.

Table 8a. Electoral results and ideological offers, 2010s elections in Europe, example 1

\begin{tabular}{|l|l|l|}
\hline & 2017 & 2013 \\
\hline $\begin{array}{l}\text { Christian democracy } \\
\text { Liberal conservatism }\end{array}$ & $26,8 \%$ & $34,1 \%$ \\
\hline Social democracy & $20,5 \%$ & $25,7 \%$ \\
\hline $\begin{array}{l}\text { National } \\
\text { conservatism }\end{array}$ & $12,6 \%$ & $4,7 \%$ \\
\hline Liberalism & $10,7 \%$ & $4,8 \%$ \\
\hline Democratic socialism & $9,2 \%$ & $8,6 \%$ \\
\hline
\end{tabular}

Source: http://www.parties-and-elections.eu/germany.html [Accessed 17/09/2017]

Table 8b. Electoral results and ideological offers, 2010s elections in Europe, example 2

\begin{tabular}{|l|c|c|}
\hline & 2015 & 2011 \\
\hline Social democracy & $26,3 \%$ & $24,9 \%$ \\
\hline $\begin{array}{l}\text { National conservatism } \\
\text { Social conservatism } \\
\text { Right-wing populism }\end{array}$ & $21,1 \%$ & $12,3 \%$ \\
\hline $\begin{array}{l}\text { Conservative liberalism } \\
\text { Agrarianism }\end{array}$ & $19,5 \%$ & $26,7 \%$ \\
\hline $\begin{array}{l}\text { Socialism } \\
\text { Eco-socialism } \\
\text { Euroscepticism }\end{array}$ & $7,8 \%$ & $6,7 \%$ \\
\hline Liberalism & $7,5 \%$ & $5,0 \%$ \\
\hline
\end{tabular}

Source: http://www.parties-and-elections.eu/denmark.html [Accessed 28/08/17]

It is interesting to notice that regardless the country, in the recent elections voters were in favor of right-wing, even far right parties. Once just exceptions, today these Eurosceptic/populist parties are at the core of the party systems, causing instability and in several situations obstructing government formations.

Table 8c. Electoral results and ideological offers, 2010s elections in Europe, example 3

\begin{tabular}{|l|l|l|}
\hline & 2017 & 2012 \\
\hline Conservative liberalism & $21,2 \%$ & $26,5 \%$ \\
\hline Right-wing populism & $13,0 \%$ & $10,1 \%$ \\
\hline Christian democracy & $12,4 \%$ & $8,5 \%$ \\
\hline Social liberalism & $12,2 \%$ & $8,0 \%$ \\
\hline $\begin{array}{l}\text { Democratic socialism } \\
\text { Euroscepticism }\end{array}$ & $9,1 \%$ & $9,6 \%$ \\
\hline Green politics & $9,1 \%$ & $2,3 \%$ \\
\hline Social democracy & $5,7 \%$ & $24,7 \%$ \\
\hline
\end{tabular}

Source: http://www.parties-and-elections.eu/netherlands.html [Accessed 4/09/2017] 
There are several final remarks that end this article. First of all, the situation of moderate left and moderate right changed significantly. As compared with the policies and ideological proposals of the 1960s-1980s, it is hard to say that we have nowadays large moderate parties. The Social Democrats are somehow close to the centre and still moderate. Their biggest problem is that they lost their political power (see table 8c) and electoral significance. Secondly, on the other part of the political arena, moderate right parties are virtually non-existent anymore. Those who were Christian Democrat or mild Conservatives four decades ago moved to the right, because of electoral or pragmatically reasons. Especially in the recent years, the expansion of far right populist parties forced them to adopt similar messages in order to preserve their voters. Thirdly, the main feature of the nowadays party systems all over Europe, not only in the Western part, is the asymmetric political scene, with several influential parties competing in the right, with few weak parties on the left side. In other words, the whole political spectrum is balanced to the right, and this could explain somehow the political unrest that is so common in Europe. Finally, to answer the question regarding the re-emergence of a political consensus between two moderate parties, one from the left, the other from the right, the answer is rather negative. It is not a valid proposal, at least not until some right-wing parties would return to the centre, and the left ones become significant again.

\section{References}

1. BAKKER, R. et al (2012) Measuring Party Positions in Europe: The Chapel Hill Expert Survey Trend File, 1999-2010. Party Politics, 21.1, pp. 143-152.

2. BÖSCH, Frank. (2004) Two Crises, Two Consolidations? Christian Democracy in Germany. In: VAN HECKE, S. and GERARD, E. (eds.) Christian Democratic Parties in Europe since the End of the Cold War. Kadoc-Studies on Religion, Culture and Society 1, Leuven: Leuven University Press, pp. 55-78.

3. BUDGE, I./ KLINGEMANN, H.-D./ VOLKENS, A./ BARA, J./ TANENBAUM, E. (2001) Mapping Policy Preferences. Estimates for Parties, Electors, and Governments 1945-1998. New York: Oxford University Press.

4. DAVIES, L. (2014) Italian birthplace of Communist party falls to Beppe Grillo's M5S. The Guardian. $9^{\text {th }}$ of June. Available from: https://www.theguardian.com/world/2014/jun/09/italian-birthplace-communist-party- 
beppe-grillo-m5s-livorno [Accessed 29/08/17]

5. INGLEHART, R. (1990) Culture Shift in Advanced Industrial Society. Princeton, NJ: Princeton University Press.

6. KITE, M. (2006) Cameron gives Hague month to get MEPs out of Brussels group. The Telegraph. $11^{\text {th }}$ of June. Available from: http://www.telegraph.co.uk/news/uknews/1520953/Cameron-gives-Hague-month-to-getMEPs-out-of-Brussels-group.html [Accessed 26/08/17]

7. KLINGEMANN, H.-D./ VOLKENS, A./ BARA, J./ BUDGE, I./ MCDONALD, M.D. (2006) Mapping Policy Preferences II: Estimates for Parties, Electors and Governments in Central and Eastern Europe, European Union and OECD 1990-2003. Oxford: Oxford University Press.

8. MISCOIU, S. (2005) Le Front National et ses répercussions sur l'échiquier politique français 1972-2002. Cluj-Napoca: EFES.

9. POLK, J. et al (2017) Explaining the salience of anti-elitism and reducing political corruption for political parties in Europe with the 2014 Chapel Hill Expert Survey data. Research \& Politics, January-March, pp. 1-9.

10. SEILER D.-L. (1993) Les partis politiques. Paris: A. Colin, coll. Cursus.

11. VAIDA, O. (2014) The Ideological Shift of the EPP. An International Content Analysis. In: DURAND, J.-D. (ed.) Christian Democrat Internationalism: its action in Europe and worldwide from post-World War II until the 1990s. Volume III. The European People's Party, continental and social cooperation. Brussels: P.I.E. Peter Lang, pp. 21-34.

12. VOLKENS, A./ BARA, J./ BUDGE, I./ MCDONALD, M. D./ KLINGEMANN, H.-D. (Eds.) (2013) Mapping Policy Preferences from Texts. Statistical Solutions for Manifesto Analysts. Oxford: Oxford University Press.

13. http://www.parties-and-elections.eu/countries.html [Accessed 26/08/17]

14. http://www.parties-and-elections.eu/content.html [Accessed 26/08/17] 


\title{
A POPULIST MOMENTUM IN THE EU?
}

\section{Robert Adam,}

Ph. D. in Political Science, Université libre de Bruxelles robertadam_99@yahoo.com

\section{DOI:10.24193/OJMNE.2017.23.02}

\begin{abstract}
Populism is one of the most used terms in political discourse, most often with a pejorative connotation, but the meaning of the term is ambiguous. The European public opinion thinks populism is on the rise in the EU. Can we therefore speak of a populist momentum in Europe? In order to answer this question, we need to clarify a few preliminary aspects: what is populism? Is there a conceptual framework of populism? What parties can be labelled populist and on what grounds? Is an anti-EU or anti-immigration stance enough to label a party populist? Inside the EU, is Western populism similar to its Eastern variety? Which would be the accurate threshold to ascertain that populism is more successful now than 5 or 20 years ago at the EU scale?
\end{abstract}

Keywords: populism, EU, parties, elections, Euroscepticism.

We argue that populism is a concept with a long history and provide a definition of populism allowing us to draw a list of European populist parties and review their recent performance in European Parliament and national legislative elections. In our view, there is no divide between Eastern and Western European populism, only minor contextual differences. If we are to speak about a populist momentum, it is not necessarily by virtue of the cumulated populist score. The major factor is the new status that populism has managed to acquire following the 2004 and 2007 successive EU enlargements. Unlike in Western Europe, in Central and Eastern Europe populist parties become mainstream and won the elections (in Hungary, Poland, Slovakia).

If there is one ubiquitous word in the political vocabulary, then it must be populism. Politicians, pundits, academics, economists, the media incessantly use it. Undoubtedly, the term has a pejorative connotation. It has almost grown into a synonym for demagoguery.

The general perception is that populism in the EU is on the rise. Can we therefore speak of a populist momentum in Europe? In order to answer this question, we need to clarify a few preliminary aspects: what is populism? Is there a conceptual framework of populism? 
Issue no. $23 / 2017$

What parties can be labelled populist and on what grounds? Is an anti-EU or anti-immigration stance enough to label a party populist? Inside the EU, is Western populism similar to its Eastern variety? Which would be the accurate threshold to ascertain that populism is more successful now than 5 or 20 years ago at the EU scale?

\section{Populism: an ambiguous concept}

If everyone seems to talk about populism, is there a consensus on the meaning of the term? By no means: if there be an arduous conceptual task, then it must be defining populism. Populism is a vague concept and the word is used almost exclusively in a negative context. Nevertheless, for more than 50 years, a rather rich literature has tackled the subject.

The stumbling block has most often been the ambiguity of the term populism. Is it an ideology or a movement? Also, as populism has mostly been defined by delimitation, by its critics rather than by its followers, this has created a wider spectrum of signification. This illegitimate birth entails a limited conceptual autonomy: populism needs to be compared to something else in order to be identified a contrario. Also, populism has often been considered a disease of representative democracy, not a doctrine in its own right.

This has not always been the case. Populism is the iron mask of democracy, the supplanted twin. Populism does have a legitimate history: people used to proudly call themselves populists and defended their political vision.

The concept of populism has been drawing the attention of social scientists for exactly half a century. The first academic symposium dedicated to populism was held on May 19-21 at the London School of Economics and its works were subsequently published in 1969 (Ionescu and Gellner, 1969).

But in order to trace the academic history of populism, one needs to follow its political history.

Populism and democracy share their roots. Populism and the nation-state were born at the same moment in history: the end of the $18^{\text {th }}$ century which brought about the French Revolution. Representative democracy won over populism as the political regime of the newborn nation-state. The people is the new sovereign, only it does not rule directly but via elected representatives. The transition was operated during the Estates-General in 1789, when the Third Estate breaks away and establishes itself as National Assembly instead of People's Assembly: the people vanishes, the nation supersedes it. The second half of the $19^{\text {th }}$ century sees it resurface in Russia and the US, with the narodniki and the American populists. 
Issue no. 23/2017

The narodniki were left-wing intellectuals opposed to the reforms meant to westernize Russia. Their doctrine blended socialism and tradition, and the role of the intellectuals was to enlighten the peasants. Strongly anti-capitalist, they dreamt of a new society built upon the model of the traditional Russian rural community, with its collective ownership of the lands. The movement was active between 1850 and 1880, and in 1876 the party Zemlia $i$ Volia (Land and Freedom) was founded. Internal disputes led to a split. The radical terrorist wing disintegrated after the assassination of Tsar Alexander II (1881).

In the US, the impulse of the populist movement did not come from the elite, but from the farmers themselves. The Farmers' Alliance, set up in 1876, was the reaction of Southern and Western farmers to the agricultural crisis of the mid 1870's. Facing low prices and mounting debts, under pressure from banks and railroads, they lobbied the federal government for regulation. As the Republican and Democrat parties were reluctant to the farmers' requests, in 1891, the People's Party, widely known also as the Populist Party, was created. Its goal was to defend the interests of the small farmer against the financial and industrial elite. As such, it advocated for the dismantling of national banks, a graduated income tax, direct election of US senators and Government control of all railroads, telegraphs and telephones.

At the 1892 presidential election, the People's Party candidate carries four states. The populists are also the first American party to accept women members. Four years later, the party decided after a lively convention to support the losing Democrat candidate. In 1900, 1904 and 1908, the party runs the presidential race. Governors, senators and congressmen were elected under its banner before the party collapsed. Nevertheless, the populist left their mark on the American political history by their appeal to increase the federal power in order to turn it into "the people's government". If their beliefs were often related to socialism, they were not socialists in their vision of private property as principle of economy. One of the key factors contributing to the transformation of Southern farmers' discontent into political populism was their engagement in the co-operative movement (Canovan, 1981, p. 54). This pattern is also visible in the second wave of political populism: Eastern European populism in the interwar period. The People's Party is already typical for a major identity problem of populism: its ambiguous position on the left-right axis.

Eastern European populism is also known as the Green Uprising. Agrarian parties met massive success in Bulgaria, Czechoslovakia, Poland, Romania and Yugoslavia. The ideology of these parties highlights private property, land reform and co-operativism and 
their usual nemesis are banks and big landlords. Nationalism is embedded in the DNA of these movements and they advocate for their people's emancipation from foreign domination and the right of the peasantry to build a society mirroring its conservative views.

The following historical waves were Latin American populism, Western European protest movements of the 1980's and 1990's and the new Eastern European populisms. 50 years of populism studies converge on only two distinctive feats shared by all populisms:

a) trust in the people;

b) anti-elitism.

Nevertheless, if these two characteristics are common to all forms of populism, they are not its exclusive prerogative. Other political visions, such as libertarianism, socialdemocracy or even Christian-democracy might well claim them in turn. Therefore the conjunction of these two features does not suffice for a minimal definition of populism. Yet the archetypal populist discourse amounts to mobilizing the virtuous common people against the corrupt elites. Considering populism a discourse in the sense given by Ernesto Laclau allows us to avoid the movement/ ideology dichotomy. So, after extensive research we have drafted the following definition of populism integrating elements from Hélio Jaguaribe, Guy Hermet, Daniele Albertazzi \& Duncan McDonnel:

Populism is the discourse rallying the people against a set of leading elites which would deprive (or attempt to deprive) the sovereign people of its rights, values, prosperity, identity and voice and which pretends to possess an instant remedy to the problems of a given society (Adam, 2016).

\section{What populist parties in the EU?}

In order to assess if there is or not a populist momentum in the EU, one needs to identify which are the populist parties referred to. The definition we have designed shall provide instrumental, as elements of populist discourse have been integrated in the political messages of parties across the political spectrum. We consider that, in order to be relevant, populist movements have to be or have been represented in Parliament over the last five years. As some countries do not have a proportional electoral system, one has to allow for parties with a significant share of voter support but little or no MPs, so we set an alternative significance threshold at $5 \%$ of the votes cast in a national election. For instance, UKIP currently has no MP in the newly-elected British parliament, but came first in the UK at the 2014 European Parliament elections. 
Issue no. 23/2017

The list of populist parties in the EU below can undoubtedly be disputed. Other parties not picked in this table have also been labelled populist by social scientists. Among those included, some are members of mainstream European parties (Direction-Social Democracy in the Party of European Socialists, Fidesz in the European People's Party). In Bulgaria, Boyko Borisov's GERB, member of the EPP, is often considered populist. From our point of view, it is a centre-right party with populist propensity. There is no Romanian representative, as Dan Diaconescu People's Party, the third political force following the 2012 general elections, ceased to exist in 2015. The Greater Romania party, which enjoyed considerable electoral success in 2000 and 2004, has also collapsed, so that for the time being there is no populist movement in the country. In Greece, Golden Dawn has sometimes been called populist: we envisage it as a far-right movement. In Cyprus, the Citizens' Alliance (SYPOL) is also regarded at times as populist: we deem it a radical left party. The Kotleba People's Party Our Slovakia does not qualify in our view to be considered right-wing populist, as there is solid ground to place it to the extreme right. Nine EU countries momentarily lack a successful populist actor: Croatia, Cyprus, Estonia, Latvia, Luxembourg, Malta, Portugal, Romania and Slovenia.

The ideological diversity of the selected parties is extreme, ranging from the far left (SYRIZA, Die Linke) to the far right (AfD, Jobbik), corroborating the idea that populism is neither right nor left. As compared to our definition, all these parties rally the people against distant elites, most often the European Union, but also the national establishment perceived as alienated from the people's needs and aspirations (FN, AfD, M5S, Unidos Podemos, UKIP). For the most left-leaning, these corrupt elites represent the capitalist system (Die Linke, SYRIZA). Some of them, as current (SYRIZA, PiS, Smer-SD, Fidesz) or former (FPÖ) ruling parties, and even as junior coalition partners (SNS, United Patriots), cannot fully play the anti-establishment card, so they resort to the unifying populist rhetoric. Unifying populism serves politicians trying to transcend cleavages, to pose as connectors. To do so, they make use of a semantic ambiguity of the term people, which can signify altogether the people as nation (dêmos), the ethnical people (ethnos) or ordinary people. Thus they can appeal to the people to seek unity for a wide range of purposes, the only constant being that the foreseen unity is made against something: the other politicians and parties if the intended audience is the people of citizens, the civic nation (dêmos); the foreigners, be they from outside the country or from within (minorities) if they address the ethnic people 
Issue no. $23 / 2017$

(ethnos); the wealthy and all sorts of elites if one intends to rally the grassroots against the powerful.

When Orbán Viktor developed the concept of illiberal democracy, it was in fact a populist democracy that he was advocating for. A democracy where supranational elites cannot sway national policies; where checks and balances are limited and the government has a strong say in economy; where the people achieves self-government and the political agenda is regulated by instruments of direct democracy (referenda). As a role-model populist, the Hungarian prime minister was disputing the theory of elitarian democracy to be defended against the people unable to grasp its level of complexity as a political system, famously elaborated by Lipset (1960).

The EU is the ideal scapegoat for populist parties, but they do not have the monopoly of Euroscepticism. Mainstream European parties, such as the British Conservatives, have been very critical of EU policies. According to their attitude towards the EU, the populist parties can be divided into hard and soft Eurosceptics. Hard Eurosceptics (Europhobes) would rather their country withdrew from the EU, while soft Eurosceptics plead for EU reform. The tough stance is roughly shared by UKIP, the National Front, the Italian 5 Star Movement, Danish People's Party, Jobbik, the Lithuanian Order and Justice, the Dutch Party for Freedom, the Sweden Democrats, part of the United Patriots electoral alliance from Bulgaria (Ataka) and the Vlaams Belang. The rest are rather to be placed on the soft Euroscepticism side.

Not surprisingly, the pro/anti-EU cleavage is most important in the European Parliament elections and less important in national ones. Some of the most Europhobic parties (UKIP, National Front, Order and Justice, the Danish People's Party) have posted massive scores in the EP polls, at least twice their tally in the national legislative ballot.

A key element when it comes to sorting which parties can be counted as populist stems from the third part of our definition ("instant remedy"). The issue is the relationship to time. The time of populism is the present continuous or the historical present. The populist speaker devises, by an emotional discourse bordering on the uchronia, an artificial time in which the historical figures from the past are called to weigh in today's political decisions. This feature is shared with nationalism. If populism can foster social and economic transformation, as it did in Latin America, the values it carries are traditional and its essence is not revolutionary. In order to overcome this dichotomy, populism needs to adopt a historical perspective. 
For Guy Hermet (2001, p. 50), this particular relationship to the political time is at the very core of populism . Populism pretends to possess immediate solutions to long-term problems. Pierre-André Taguieff (2001, p. 406) places the time of populism in a magical dimension: "The time of populism is a mythical time, and populist action has a lot to do with political magic."

Most of the parties in the table have made use of the instant remedy policy to lure voters (United Patriots, Volya, FN, SYRIZA, Jobbik, M5S, PVV, Smer-SD, SNS, Unidos Podemos being the most conspicuous and consistent in this practice). This tactic is all the more effective as the party is certain not to be able to take office, but some of these parties eventually did, which led in the aftermath to a more cautious approach (SYRIZA, Smer-SD).

UKIP's and Leave campaign's pledge to redirect $£ 350$ million per week from UK’s net contribution to the EU budget towards the British National Health Service was one of the most powerful arguments for the Brexit vote in the 2016 referendum. Upon victory, nobody backed this promise anymore, as it turned out the figure was grossly inaccurate. In the ensuing national elections in June 2017, the UKIP crashed at $1.8 \%$, down from $12.6 \%$ in the 2013 legislative polls and $27.5 \%$ in the 2014 EP elections.

EU populist parties' results in the 2014 European Parliament elections and last national elections

\begin{tabular}{|l|l|l|l|l|l|}
\hline Country & Populist Party & $\% \mathrm{EP} 14$ & $\%$ Nat & Rank & $\%$ Change \\
\hline Austria & Austrian Freedom Party (FPÖ) & 19.7 & 20.5 & 3 & +1.5 \\
\hline Belgium & Flemish Interest (Vlaams Belang) & 4.1 & 3.7 & 10 & -5.7 \\
\hline Bulgaria & United Patriots & & 9.0 & 3 & - \\
\hline Bulgaria & Volya & & 4,1 & 5 & - \\
\hline Czech Rep & Dawn of Direct Democracy & 3.1 & 6,9 & 6 & - \\
\hline Denmark & Danish People's Party & 26.6 & 12.3 & 2 & -1.6 \\
\hline Finland & Finns Party & 12.9 & 19.1 & 2 & -1.4 \\
\hline France & National Front (FN) & 25.0 & 13.2 & 3 & -0.4 \\
\hline Germany & Alternative for Germany (AfD) & 7,1 & 12,6 & 3 & +7.9 \\
\hline Germany & The Left & 7.3 & 9.2 & 5 & +0.6 \\
\hline Greece & Coalition of the Radical Left (SYRIZA) & 26.6 & 35.5 & 1 & -0.8 \\
\hline Hungary & Fidesz - Hungarian Civic Union & 51.5 & 44.5 & 1 & -4.3 \\
\hline Hungary & Movement for a better Hungary (Jobbik) & 14.7 & 20.2 & 3 & +3.5 \\
\hline
\end{tabular}


Issue no. 23/2017

\begin{tabular}{|l|l|l|l|l|l|}
\hline Ireland & Sinn Fein & 19.5 & 13.8 & 3 & +3.9 \\
\hline Italy & Five Star Movement (M5S) & 21.2 & 25.6 & 1 & +5.6 \\
\hline Lithuania & Order and Justice & 14.3 & 5.6 & 7 & -1.7 \\
\hline Netherlands & Party for Freedom (PVV) & 13.2 & 13.1 & 2 & +3.0 \\
\hline Poland & Law and Justice (PiS) & 31.8 & 37.6 & 1 & +7.7 \\
\hline Slovakia & Direction-Social Democracy (Smer-SD) & 24.1 & 28.3 & 1 & -16.1 \\
\hline Slovakia & Slovak National Party (SNS) & 3.6 & 8.6 & 4 & +4.1 \\
\hline Spain & United We Can (Unidos Podemos) & 8.0 & 21.2 & 3 & -3.3 \\
\hline Sweden & Sweden Democrats (SD) & 9.7 & 12.9 & 3 & +7.2 \\
\hline UK & UK Independence Party (UKIP) & 27.5 & 1,8 & 3 & -10.8 \\
\hline
\end{tabular}

\section{Eastern vs. Western populism}

As populism is not an ideology, insofar it is unable to provide a comprehensive worldview, and very few parties acknowledge a populist vision, it is an uphill task to gather parties from countries with diverse national contexts under this label. One of the recurrent issues has been the East/ West divide: is the populism of former communist countries in Central and Eastern Europe the same political phenomenon as the one in Western Europe? As the public opinion in Central and Eastern Europe (CEE) is rather positive about the EU (according to the Eurobarometer 87 - Spring 2017, 10 out of 11 CEE audiences profess more trust in the EU than the EU28 average), can populist parties in these countries be as Europhobic as the Western ones and still make electoral breakthroughs? Anti-immigrant discourse is a must for Western populist parties. The CEE is hardly a destination for immigration, on the contrary, millions of Eastern Europeans have turned the West into their new home and as a result they are being targeted by the recriminations of Western populist parties: they take the jobs of the natives, work for lower wages, increase criminality. In these conditions, can populist parties from Western Europe co-operate with their Eastern counterparts? Do the voters of populist parties have a similar profile, or even is there a resemblance between the followers of all populisms in history, is there a generic people of populism who would be the cornerstone of this sociopolitical construct?

We shall strive to answer in the first place the last question, as it is the most general. The answer cannot help being ambivalent. Yes, because the critical mass of populism has always been represented by the losers of a socio-economic process of transformation. No, because there is an essential change of the target: 'ancient' populism (until WWII) defended labour (peasants, farmers, industrial workers) against the idle wealthy, the oppressive 
Issue no. $23 / 2017$

government and huge capital (opposing the small people to the big), modern populism is the voice of a middle people discontent with the "privileges" conceded to the poorest: the average rebel against the "excessive" welfare conceded to the smallest (including the refugees).

Modern populism is perhaps older than one might think. As soon as 1935, US social scientist David J. Saposs (p. 393) interpreted "Fascism being the extreme expression of middle-classism or populism".

The audience of today's populism are the losers of modernization, those who risk the deterioration of their status because of social transformation, whatever the reasons of this transformation (globalization in Western Europe since the 1980's, transition in Central and Eastern Europe from the fall of communism in 1989 until the accession of these countries to the EU in 2004 and respectively 2007 for Bulgaria and Romania, 2014 for Croatia).

The EU accession of CEE countries has levelled the field of populism in many aspects. The populist vote is a protest vote. The surveys conducted EU-wide have revealed the profile of populist voters is more or less the same across Europe: nativist, authoritarian personalities, Europhobic (more so in Western Europe) and anti-immigration (in the "old Europe)/ xenophobic or hostile to ethnic minorities (in the "new Europe"), fearing modernization and discontent with politics.

The more someone is displeased with politics, the greater the odds s/he voted for a populist party. When the messages conveyed by mainstream political parties (e.g. the need for austerity policies in Greece after the financial crisis) are too similar and the ideological cleavages almost obliterated, an avenue opens for populist movements. Crisis fuels their appeal. Populism has been perceived as a disease of representative democracy from the very first conference in 1967 where Peter Wiles (1969, p. 166) deemed it "A Syndrome, not a Doctrine". If Central and Eastern European democracies are younger then Western ones, the disenchantment with the national political establishment reaches record heights in the region. Only $33 \%$ of Romanians trust their government and 27\% their Parliament, while for Poland the corresponding figures stand at 33\% and 25\%, much lower than the EU28 average (Eurobarometer 87 Spring 2017).

When it comes to the anti-immigration stance, Eastern populists are as radical as the Western ones. They echo their national public opinion, with 11 out of the 15 most hostile countries to immigration from outside the EU hailing from the former communist bloc, ranging from a record $83 \%$ of negative opinions in Latvia to Romania's 59\% (Eurobarometer 
Issue no. $23 / 2017$

86, Autumn 2016). The only "intruders" are countries highly impacted by the refugee crisis (Greece, Italy, Malta). As the Visegrad group (Czech Republic, Hungary, Poland, Slovakia) refused to take part in the EU's refugee relocation scheme, domestic support for this position was overwhelming.

Central and Eastern European parties are seldom hard Eurosceptics (save for Jobbik, Ataka and Order and Justice), because the image of the EU as source of prosperity is still dominant in the region. However, the Fidesz and the PiS, as ruling parties, have joined efforts at EU level to convey a political message that stands in defiance of the liberal democratic model and have thus become models for Western populist parties which, though theoretically more hostile to the EU, lack the means to harm EU policies and can only express tough criticism in the European Parliament.

In conclusion, there is no divide between Eastern and Western European populism, only minor contextual differences.

\section{Is there a populist momentum in the EU?}

In the final part of this paper, the time has come to answer the initial question: can we speak of a populist momentum in the EU? Is there a threshold or an indicator to assess it?

Populist parties have posted big wins in the 2014 European elections. The Fidesz, Smer-SD, UKIP, SYRIZA, the Danish People's Party, the National Front emerged as victors, the PiS was very close to do so and scored a very high result, Sinn Fein came second close enough to the winner and the 5 Star Movement rose to more than 20\%. However, many of these parties drew lower support in the subsequent national legislative elections, most notably in France, UK and Ireland. Their scores at the EP elections are not necessarily a relevant indicator, as these tend to be a single-issue ballot: pro/ anti-EU. As in many countries the populists monopolize the Europhobic discourse (though not so in France, Italy and the UK), they took advantage of this unique cleavage to maximize their gains.

2014 saw a strong anti-establishment vote, with Eurosceptic parties taking roughly a quarter of the EP seats. As there is no united Eurosceptic front in the Parliament, but also because of the historical tradition of bi-partisan co-operation between the major political groups (EPP and S\&D) to reach majority on important issues, the populists, despite their numbers, remain marginal. Though no causal relationship can be drawn, since spring 2014 and the last EP elections, trust in the EU has soared at European level at $42 \%$ in spring 2017, up from 31\% (source: Eurobarometer). 
In our view, if we are to speak about a populist momentum in present day Europe, it is not necessarily by virtue of the cumulated populist score. EU28 is radically different from the EU15, where populist parties also achieved significant success. The major factor is the new status that populism has managed to acquire following the 2004 and 2007 successive EU enlargements. In 1999, when Jörg Haider's Freedom Party (FPÖ) entered government following a strong display in the elections, as the junior partner despite a slightly better score compared to the ÖVP, the other 14 members of the EU imposed diplomatic sanctions on Austria in February 2000 (they were only lifted in September 2000). In Western Europe, populist parties have been associated with the extreme right and subjected to a cordon sanitaire, which is still in place in France towards the FN or in Germany towards the AfD.

These pre-emptive sanctions would be unthinkable today, with populists like Orbán Viktor, Robert Fico or Beata Szydlo sitting in the European Council.

In Central and Eastern Europe, populism has become mainstream and in some countries, like Slovakia, populist parties have dominated the political stage in the long run. As a conclusion, if there is now a populist momentum in the EU, it is mostly a consequence of the enlargements to the East. The different political culture in some of these countries has brought the populists to the table. And they are here to stay.

\section{Bibliography}

- ADAM, R. (2016) National-populisme en Roumanie. Tradition et renouveau postcommuniste. Brussels: Ph. D. dissertation defended at the Universite libre de Bruxelles.

- AlbertaZZI, D./ McDONNEL, D. (2007) Twenty-First Century Populism: The Spectre of Western European Democracy. New York \& London: Palgrave Macmillan.

- CANOVAN, M. (1981) Populism. New York \& London: Harcourt Brace Jovanovich.

- HERMET, G. (2001) Les populismes dans le monde : une histoire sociologique XIX $-X X^{e}$ siècle. Paris: Fayard.

- IONESCU, G./ GELlNER, E. (eds.) (1969) Populism. Its Meanings and National Characteristics. London: Weidenfeld and Nicolson.

- JAgUARIBE, H. (1967) Problemas do desenvolvimento latinoamericano. Rio de Janeiro: Civilizaçao Brasileira. 
- LACLAU, E. (1977) Politics and Ideology in Marxist Theory: Capitalism-FascismPopulism. London: Verso.

- LAClAU, E. (2005) On Populist Reason. London \& New York: Verso.

- LIPSET, S.M. (1960) Political Man: The Social Bases of Politics. New York: Doubleday.

- SAPOSS, D.J. (1935) The Role of the Middle Class in Social Development: Fascism, Populism, Communism, Socialism. In: Economic Essays in Honor of Wesley Clair Mitchell. New York: Columbia University Press, pp. 393-424.

- TAGUIEFF, P.-A. (2001) Populisme, nationalisme, national-populisme. Réflexions critiques sur les approches, les usages et les modèles. In: DELANNOI, G./ TAGUIEFF, P.-A. (sous la dir.) Nationalismes en perspective. Paris: Berg International, pp. 303-398.

- WILES, P. (1969) A Syndrome, Not a Doctrine: Some Elementary Theses on Populism. In: IONESCU, G./ GELLNER, E. (eds.) (1969) Populism. Its Meanings and National Characteristics. London: Weidenfeld and Nicolson, pp. 166-179.

\section{ELECTRONIC REFERENCES}

- European Parliament elections: http://www.europarl.europa.eu/elections2014results/en/election-results-2014.html [Accessed 15/09/17].

- National legislative elections: http://www.parties-and-elections.eu/ [Accessed 15/09/17]. 


\title{
FRAGMENTATION, FLUIDITY AND PERSONALIZATION: REMARKS ON SHIFTS IN THE PRO-EUROPEAN PARTY SPECTRUM IN THE REPUBLIC OF MOLDOVA AFTER 2014
}

\author{
Andrei Avram \\ MA (Freie Universität Berlin) \\ Program coordinator, Romania Office, Konrad-Adenauer-Stiftung \\ Andrei.avram@kas.de
}

\section{DOI:10.24193/OJMNE.2017.23.03}

\begin{abstract}
The political party system in the Republic of Moldova has been characterized by instability and divisions along geopolitical lines ever since the country gained independence. Institutional volatility continues to affect especially the pro-European party spectrum and hampers efforts to consolidate the Moldovan center-right. The article argues that the recent reconfiguration among pro-Western forces illustrates how the main traits of the Moldovan party system - fragmentation, fluidity and personalization - were exacerbated by the political, economic and social instability that ensued immediately after the parliamentary elections in November 2014. With the next ballot scheduled to take place in late 2018, it will be essential for center-right parties to overcome these structural weaknesses and find a path towards consolidation.
\end{abstract}

Keywords: Party system, democratization, fragmentation, Republic of Moldova.

Multiparty systems in Central and European countries have since their emergence following decades of one-party-rule and Soviet dominance been viewed as having an essential role of both overcoming the legacies of the Communist period as well as in contributing to the sustainable political transformation of the states of the "third wave of democratisation" (Dellenbrant, 1993, p. 148). Yet it remains largely consensus within the literature that political parties in younger democracies, including Eastern Europe, "are less stable" and that they tend to "split, merge and form and dissolve electoral coalitions and alliances" (Ibenskas and Sikk, 2016). These general observations also hold true for the party landscape of the Republic of Moldova, which has in the past been characterized as "one of the most fluid (...) in Eastern Europe" (Nemerenco, 2008, p. 35), encompassing "executive and personalistic" (Nelson et al., 2010, p. 1) political forces. 
Issue no. 23/2017

More specifically however, the party spectrum in the Republic of Moldova has been divided across geopolitical boundaries, with left-wing structures typically opting for rapprochement with the East, and right-wing forces adopting a pro-Western stance (Boţan, 2016). This split - initially between proponents of integration in the Commonwealth of Independent States (CIS), nowadays of the Eurasian Economic Union (EEU), on the one hand, and those advocating closer ties with the European Union (EU) on the other hand - also reflects different views regarding the cornerstones of the Moldovan political system as a whole, with only the latter being (fully) committed to the model of liberal democracy, whereas the former's set of values include statism, authoritarianism and egalitarianism (Protsyk, Bucătaru and Volentir, 2008, p. 91). These inclinations appeal to a significant part of the electorate in the Republic of Moldova, where migration in the past years has depleted the "ranks" of the urban, working-age, better-educated (potential) middle-class, i.e. what could be the core voters of the center-right. It should also be mentioned that this constellation resulted from an initial divide between forces advocating for the re-establishment of the Soviet state and those in favor of (re-)unification with Romania (Pisica, 2013, p. 312), which subsequently complementarily adopted a pro-European discourse as well.

The complexity of the party landscape in the Republic of Moldova is further augmented by the fact that - despite the existence of two antagonistic foreign policy vectors centrist actors also ensued, with even the first Parliament of the newly-sovereign Republic of Moldova roughly equally divided between the right-wing, Romania-leaning Popular Front, the left-wing pro-Soviet Interfront and what would become the centrist Democratic Agrarian Party of Moldova. In more recent times, it was the Democratic Party of Moldova (PDM) to occupy the position of the latter, being nowadays firmly - at a declarative level - engaged in pro-European rhetoric, but having as late as 2010 initially explored the option of becoming part of a pro-Russian coalition (Boţan, 2016). Furthermore, the Party of Communists of the Republic of Moldova, which dominated the political arena between 2001 and 2009, oscillated between staunch support for closer ties with Russia (until 2003), European integration (2003 - 2009), before reverting to its Eastwards-looking stance. Notably though, center-right Moldovan political forces have since independence been more constant in their geopolitical outlook, with the main differentiating element related to the differing position on possible union with Romania, but not on the pursuit of European integration per se.

This paper aims to very briefly shed light upon shifts in the pro-European party spectrum in the Republic of Moldova in recent years, after the parliamentary elections in 
Issue no. $23 / 2017$

2014 which were followed by a reconfiguration of the center-right forces in the country, in the aftermath of what became publicly known as "the theft of the billion" ("furtul miliardului"), when ca. 1 billion US dollars (representing no less than 12 percent of the Moldovan GDP) disappeared from three Moldovan banks and which generated a profound crisis of trust in the pro-European parties in government. Since this article represents work in progress only - given also the recentness of the developments it touches upon - it does not have the intention to exhaustively cover the topic concerned, but rather to offer an impulse for more profound research in this regard. Also, the present paper does not seek to analyze the broader political ramifications of the on-going political crisis in the Republic of Moldova.

The relevance of understanding the evolution of the pro-European parties in the Republic of Moldova is not limited to the scope of political party analysis. In societies engaged in transformation processes, parties "are the vital point of connection between society and government" and since integration - whether in Eastern or Western structures represents, at least to a certain extent, a raison d'être of transformation as such, it is the role of parties to not only "filter demands and organize them into more or less coherent policy" (Dellebrant, 1993, p. 148), but also to convey to - a more or less disoriented population wherein the destination of transformation lies. Moreover, in the case of the Moldovan political system, the role of parties has been more important than in other post-Soviet states, like Russia or the Ukraine (Büscher, 2004, p. 536), especially due to the fact that initially the 1994 Constitution provided for a semi-presidential system (with a stronger role for Parliament compared to other CIS countries), which was replaced in 2000 by a parliamentary system, thus further enhancing the position of political parties (Büscher and Avram, 2012, p. 294). A further contributing factor in this respect is the election of the Moldovan parliament based upon the proportional representation of parties ever since 1994 (Protsyk, Bucătaru and Volentir, 2008, pp. 43-44), which is to be replaced by a mixed system in a controversial move of the current government, voted upon by Parliament in July 2017 (Sieg, 2017). The proportional system adopted in 1994 "equipped party leaders with the ability to control the majority" (Webster, 2008, p. 232).

Nevertheless, while the systemic prerequisites for a functioning multiparty system have been in place for over two decades, the Moldovan party landscape has not yet reached institutional maturity. The proportional voting system strengthened the role of the party chairmen, but the fact that subsequently new forces emerged centered upon the figure of the founding leader hindered the institutional consolidation of the parties themselves (Bucătaru, 
Issue no. 23/2017

2013, p. 57). Furthermore, this trait of the Moldovan system entails the risk of the party disappearing or losing political relevance, once the founder leaves the political field - a risk further exacerbated by Moldovan parties' high reliance on the personal charisma of the leader (Pisica, 2013, p. 314) .

A further problematic issue is related to the fact that, until 2016, political parties in the Republic of Moldova received no subsidies from the state budget and - given the dire social and economic situation - could also not raise significant funding through membership fees, thus having to rely on donations from private persons or entities. In fact, a recent study pointed out that in 2014, the two main parties in the coalition government, the PDM and the center-right Liberal Democrat Party of Moldova (PLDM), obtained 100 (!) and 60 percent respectively of their funding from individuals, whereas their former (and subsequent) coalition partner, the Liberal Party (PL), also relied entirely (!) on contributions of private persons (Asociaţia Promo-Lex, 2016, p. 23). These structural deficiencies were to lie at the heart of the reconfiguration of the center-right spectrum of the Moldovan party landscape.

In geopolitical terms, the parliamentary election on the $30^{\text {th }}$ of November 2014 produced a majority for the pro-European vector, with the center-right PLDM obtaining 20.16 percent of the votes (23 seats in Parliament), the pan-Romanian PL 9.67 percent (13 seats) and the centrist PDM 15.80 percent (19 seats), totaling 55 seats out of 101 . The highest number of seats (25) was won by the explicitly pro-Russian Party of Socialists (PSRM), led by Igor Dodon, who had defected from the PCRM in 2011, and was shortly thereafter elected PSRM chairman.

However, after the election the afore-mentioned banking scandal was revealed to the public, leading to "a profound political, economic and financial crisis, against the backdrop of an ample protest movement" (Boţan, 2016). Despite long-running coalition talks, by February 2015 only a minority government composed of PLDM and PDM ministers, with parliamentary support of the Communists, could be formed - and only after the initial candidate for the post of premier, the incumbent Iurie Leancă (PLDM), had failed to obtain a vote of confidence, having to be replaced by Chiril Gaburici (backed by the PLDM).

Leancă subsequently left the PLDM and founded the European People's Party of Moldova (PPEM) in a first step of the reconfiguration and renewal of the Moldovan centerright. As part of an electoral platform comprising mostly dissidents from the PLDM, the PPEM took part in local elections on June 14, 2015, obtaining about 7.6 percent of the vote, whereas the PLDM reached a nationwide score of 18.3 percent and the PL 12.6 percent 
(Boţan, 2015). Notably however, in the capital Chișinău - where voting behavior in local elections is more party-oriented than in rural areas - the PPEM became the second-strongest party (after PSRM), with a score of 11.58 percent of the votes for the Municipal Council, whereas the PLDM "had to swallow (...) a bitter pill" in seeing its score fall from over 14 percent (in 2011) to only 3.52 percent (Irmer, 2015, p. 3). Thus, Leancă's move to create his own political movement generated a new element of fragmentation of the center-right Moldovan party landscape, which initially affected only the PLDM (Boţan, 2015).

Not even after the local elections did the crisis in the Republic of Moldova show any signs of abating. Two days before the vote, Gaburici had announced his resignation following a scandal related to his school diploma, and it was only on the $30^{\text {th }}$ of July 2015 that a new government could be formed, led by Valeriu Strelet (PLDM), with the PL and PDM as coalition partners. This cabinet was also destined to be short-lived, with one of the most significant "political earthquakes" in Moldovan politics waiting to take place: on the $15^{\text {th }}$ of October 2015, upon a request by the Prosecutor General of the Republic of Moldova, Parliament voted to strip the founding leader of the PLDM, Vlad Filat, of his parliamentary immunity - a decision which was supported by all parties (PSRM, PCRM, PL, PDM), except for Filat's own party. A few hours later, Filat, who had also served as Prime Minister between 2009 and 2013, was arrested, being accused of corruption offences and of involvement in the "theft of the billion".

With Vlad Filat removed from political life - he was sentenced to nine years in prison only a few months later - the PLDM was plunged in a profound, existential crisis, further deepened by a vote of no-confidence initiated by the Socialists and Communists and supported by the PDM, resulting in the ouster of the Strelet government. In terms of public trust, by November of the same year it had fallen from 15.7 percent in April to 5 percent and in terms of voter intention from 7.1 percent to only 2 percent. These figures at least partly tally with Filat's demise as a public figure, with his trust ratings dropping from 11.9 (April 2015) (Institutul de Politici Publice, 2015a, p. 41) to 3 percent (November 2015) (Institutul de Politici Publice, 2015b, p. 38). Subsequently, the PLDM lost a number of MPs, who left the parliamentary group and a number of which supported a newly-formed ad-hoc coalition of the PDM, PL, and deputies who had resigned from the PCRM, leading to the formation of a new coalition government under Prime Minister Pavel Filip (PDM) in January 2016. The magnitude of the losses incurred by the PLDM in terms of political influence and voting 
Issue no. 23/2017

intention is huge: today it only has five MPs, with only 0.8 percent of Moldovans signaling their wish to vote for the Liberal Democrats in the upcoming parliamentary election.

It would certainly be a methodological error to mono-causally link Filat's fate to the decline of the party he had founded in 2007. Many observers note that he had long been engaged in a feud with the main backer and present-day Chairman of the PDM, Vladimir Plahotniuc, who is widely considered to be the most powerful political and business figure in the Republic of Moldova, and that at least some of the defections from the PLDM resulted from various forms of pressure exerted by Plahotniuc. ${ }^{9}$ But despite the issues regarding pluralism and the rule of law in the Republic of Moldova, it is also clear that the PLDM lacked the institutional resources required to recover from the disappearance of its leader from the political stage.

Notably, the PLDM had in the past also profited from the positive image of Iurie Leancă, whose position as Prime Minister (March 2013 - February 2015) had contributed to his notoriety and who had been more popular than Filat for some time. In November 2014, Leancă's trust rating was 42 percent, whereas Filat stood at only 26 percent (Institutul de Politici Publice, 2014, p. 44). By leaving the PLDM, Leancă initially avoided incurring the same high political costs in terms of image, although certain segments of the media had associated him with the banking scandal as well, especially as "the theft of the billion" had taken place under his tenure as premier. Leancă scored a 37 percent positive trust rating in April 2015 - more than any other Moldovan politician - which declined to a still-positive 30 percent by November 2015. In this context, he could successfully transfer his image upon the PPEM, which was registered in August 2015, and achieved a trust rating of 28 percent in November 2015, with a voter intention of 7 percent (Institutul de Politici Publice, 2015b, pp. $40,42)$.

The public success of the PPEM was limited, however, confirming the fluidity of the Moldovan party spectrum, especially on the center-right. After its initial success as "a proEuropean alternative to the compromised political parties", experts warned that an eventual PPEM rapprochement towards the ruling coalition risked bringing about its downfall (e.g. Boţan, 2015). Precisely this was to happen, with Leancă's party signing a partnership agreement with the governmental coalition in July 2016. By October 2016, the voter intention rate of the PPEM had plummeted to 1.7 percent, with public trust at just 11.6 percent

\footnotetext{
${ }^{9}$ Private ("Chatham House rules") discussions the author attended.
} 
(Institutul de Politici Publice, 2016b, pp. 57, 60). At the presidential election on October 30, 2016, Leancă obtained 3.11 percent of votes. By the time of the presidential vote, however, other center-right actors had already been dominating the pro-European Moldovan party spectrum.

The "theft of the billion" also represented a catalyst for some of the most significant street protests in the history of the country. On February 24, 2015, a civic movement called Platform Dignity and Truth was constituted, with several public intellectuals and experts at the forefront thereof, which later was at the forefront of demonstrations organised against the ruling coalition. During the "autumn of protests" (Irmer and Avram, 2015b), tens of thousands of people were mobilized for mass protests in September, and the main square in Chişinău - in front of the seat of the government - was occupied by tents set up by supporters of the Platform. On the $13^{\text {th }}$ of December 2015, part of the leaders of the civic platform created the Party Platform Dignity and Truth (PPDA), with lawyer Andrei Năstase elected chairman at the first congress of the new political force.

Năstase had already established himself as one of the most vocal critics of the government and of Vladimir Plahotniuc. Although expressing its support for the European path of the Republic of Moldova, the PPDA also became an anti-establishment party, with its leader "polarizing [public opinion, A.A.] very well" (Goşu, 2016). This charismatic approach bore well with the Moldovan public. In November 2015, Năstase reached a positive public trust rating of 29 percent (Institutul de Politici Publice, 2015b, p. 38) - quite a significant result, given the fact that he was not even known to 22 percent of those polled. The Platform - at that moment not officially registered as a party - obtained a score of 32 percent positive trust (Institutul de Politici Publice, 2015b, p. 40), already surpassing Leancă's PPEM. With the protest movement slightly losing momentum in the following spring, not least because one of the key demands thereof - direct elections for the president of the Republic of Moldova - had been met by a (controversial) decision of the Consitutional Court, Năstase's popularity also started to decrease. In April 2016, his positive rating stood at 22.2 percent, with the PPDA at 21.8 percent and a voter intention of 9 percent (Institutul de Politici Publice, 2016a, pp. 37, 44, 47).

Not only protest fatigue was the cause for Năstase and the PPDA's slight decline in rates. On the $23^{\text {rd }}$ of December 2016, Maia Sandu - who had served as Minister of Education under Vlad Filat with support from the PLDM, but had not been a party member - announced her intention to create a new political party, which held its founding congress on May 15, 
Issue no. 23/2017

2016. The statute of the new, center-right Party Action and Solidarity (PAS) mentioned its commitment to European integration (Partidul Acţiune şi Solidaritate, 2016, p. 4). Sandu already had a reputation as an uncompromising reform-oriented figure, but had not been actively involved in party politics before. In the summer of 2015 , she had been nominated by the PLDM for the post of Prime Minister, but was rejected by the PDM and PL, after she had put forward a number of conditions enabling her to be independent in her decisions, such as a right to reject minister proposals from the coalition partners and a public commitment of coalition party leaders to necessary reforms (Irmer and Avram, 2015a). This attitude was well received by the Moldovan public opinion and in November 2015 Maia Sandu was credited with a 39 percent positive trust rating (Institutul de Politici Publice, 2015b, p. 38). By April 2016, this figure had decreased to 31 percent - but this still represented the highest score among all leading Moldovan politicians. At the same time, PAS had a positive trust rating of 26.4 percent and 11.1 percent voter intent (Institutul de Politici Publice, 2016a, pp. 37, 44, 47).

A special note should also be made regarding the Liberal Party (PL), which had been able to slightly enhance its electoral score at the local elections in summer 2015 (from 9.67 to 12.62 percent), thus initially avoiding the decline of the PLDM, not least thanks to the "[geo]political" vote for the mayor of Chişinău, where the incumbent Dorin Chirtoacă (and nephew of PL chairman Mihai Ghimpu) had managed to maintain his position, thanks to the polarization of the electorate in the capital between him and the PSRM pro-Russian candidate Zinaida Greceanîi (Boţan, 2015). Chirtoacă had always been more popular than his uncle and the PL had been dependent on his image as well as on Ghimpu's and in the context of the PL's tactical refusal to initially be part of the governmental coalition in the first half of 2015, the trust ratings of Chirtoacă, Ghimpu and the PL did not suffer from the image blows incurred by the PLDM (and the centrist PDM). In April 2015 Chirtoacă stood at a national positive trust rating of 33.8 percent (second only to Iurie Leancă), Ghimpu at 21.2 percent and the PL at 21.9 percent (Institutul de Politici Publice, 2015a, pp. 41-43). However, the subsequent "political earthquake" also left its mark on the PL. In November 2015 Ghimpu's rating was down to 13 percent, and the PL had declined to 14 percent positive trust, with only 5 percent voter intent (Institutul de Politici Publice, 2015b, pp. 38, 40, 42) - lower than the electoral threshold of 6 percent. Significantly, Chirtoacă still had a trust rating of 30 percent, but unlike at the local elections where he had a prominent role to play, a positive image transfer between him and the party led by his uncle could not take place on the level of 
Issue no. $23 / 2017$

national politics in the context of the reconfiguration of the center-right and the emergence of new actors. The downward spiral of the PL continued into the spring of 2016 - after the PL had joined the new government under premier Pavel Filip. In April 2016, Ghimpu was trusted by only 5.4 percent of the Moldovan public, with the PL at 6.2 percent and a voter intent of only 1.7 percent (Institutul de Politici Publice, 2016a, pp. 37, 44, 47). Chirtoacă, also in decline at 17.4 percent, was still much better placed than both Ghimpu and the PL.

The decision of the Constitutional Court of the Republic of Moldova in March 2016 to reinstate the direct election of the President had thus occurred at a moment when the center-right spectrum of the Moldovan had suffered its most significant wave of fragmentation for several years. The established center-right parties PLDM and PL were in decline, the PPEM had already reached its inflection point and PAS and PPDA had established themselves as relevant pro-European political forces. Given the already personalized nature of the Moldovan party landscape, it appears natural that a direct presidential vote would exacerbate this trait, as presidentialism encourages individual responsibility, since "presidential executive authority resides with an individual who is elected to the position for a fixed period of time" (Kesteloot, De Vries and and De Landtsheer, 2008, pp. 78-79).

In an (ultimately unsuccessful) effort to prevent an electoral win by Igor Dodon, three center-right parties - PLDM, PAS and PPDA - committed to field a common candidate in a move supported by the European People's Party, of which the PLDM is an observermember. ${ }^{10}$ From the very outset, the PLDM decided not to nominate any potential candidate, whereas both PAS and PPDA proposed their respective leaders, Maia Sandu and Andrei Năstase, who both initially entered the presidential race. Despite tensions between the two, Năstase agreed to withdraw from the campaign (and actively supported Maia Sandu) after a poll commissioned by the Konrad-Adenauer-Stiftung revealed that voter intent was higher for Sandu (14.3 percent) than Năstase (13 percent).${ }^{11}$ Moreover, the study had shown that in case of Sandu's withdrawal, only 21.9 percent would vote for Năstase, whereas if the latter would pull out, Maia Sandu could garner 26.54 percent - and thus be better placed in the run-off vote against Dodon, whose entry into the second round had been certain from the very outset. Maia Sandu's first-round result of 38.71 percent was also facilitated by the withdrawal of

\footnotetext{
10 The EPP also (unsuccessfully) appealed to Iurie Leancă to support Maia Sandu as well. For the full press release, see: http://www.epp.eu/press-releases/epp-fully-endorses-maia-sandu-as-the-only-candidate-of-the-centre-right-in-moldovas-presidentialelections/ [Accessed 09/09/17].

${ }^{11}$ The full (unpublished) results are in possession of the author.
} 
Issue no. $23 / 2017$

PDM candidate Marian Lupu, and although she lost the run-off, her score of 47.89 percent was higher than most observers had anticipated. Notably, the other two relevant center-right candidates, Iurie Leancă and Mihai Ghimpu, scored very poorly at 3.11 and 1.80 percent respectively.

While Maia Sandu and Andrei Năstase had been running "neck and neck" in the months before the presidential vote, the fact that ultimately the pro-European party spectrum rallied around the former (Leancă also explicitly endorsed her in the second round) created a new layer of personalization, centered around her. This also impacted upon the ratings of her party - but especially on those of potential competitors in the center-right segment of the political landscape. In April 2017, PAS had a positive trust rating of 38 percent, whereas the PPDA only scored 25 percent. These figures largely correspond to the personal ratings of the two party leaders, with Sandu at 38 percent and Năstase at 28. More significantly though is that when it comes to voter intent, PAS now stands at 24.8 percent and the PPDA at only 4.6 percent (Institutul de Politici Publice, 2017, pp. 47, 50, 55). Thus, it appears that Sandu's electoral performance has convinced voters that her party may be a more reliable (or "safer") option - having seen how the PAS chairwoman can handle an electoral campaign - even if they may also trust the other major center-right political force.

In what would seem to be a negative effect of personalization, both the PPEM and the PL now have historically low polling ratings, with voter intent standing at 1.3 and 0.8 percent respectively. The dismal scores of their leaders in the presidential election will have certainly played a role. Even the positive trust ratings of the two parties are quite low, at 12 and 7 percent. Significantly, the PLDM's open support for Maia Sandu during the electoral campaign - which also meant that there was no active promotion of the image of the party's current leader, Viorel Cibotaru - has pushed its ratings even lower. Positive trust lay at 6 percent in April of this year, whereas voter intent was almost irrelevant at 0.2 percent.

The present paper has shown that the Moldovan pro-European, center-right party spectrum has retained three characteristic traits - fragmentation, fluidity and personalization - with the most recent reconfiguration wave proving that the structural weaknesses of the party system have not fundamentally changed since independence. The established parties PLDM and PL declined alongside their founding leaders, whereas the newly-formed PPEM initially benefitted from the positive image of its chairman, before he also lost the faith of Moldovan voters - along with his still-young political force. Andrei Năstase and Maia Sandu could successfully transfer their positive public images onto their parties, with Sandu later 
Issue no. $23 / 2017$

benefitting from the attention she received during the presidential vote, at least partly at the expense of Năstase's PPDA. It remains to be seen whether this initial cannibalization translates into a longer-term trend.

Moreover, it should be mentioned that while the left was also shaken by the demise of the PCRM - the electorate of which was largely taken over by the Socialists - it is the proWestern spectrum of the Moldovan party landscape that is still in desperate need of consolidation. After Igor Dodon's election as president, the Socialists dominance in the proRussian spectrum has become uncontested, with their voter intent standing at 33.6 percent. While the electoral chances of a common electoral block comprising at least the three parties which supported the idea of a single pro-European candidate in the presidential vote would need to be tested in an opinion poll, the chances of the center-right parties running separately would almost certainly be lower. Should this step not be taken, there appears to be no guarantee that after 2018 a new wave of reconfiguration of the center-right does not yet again shake up Moldovan politics.

\section{References}

- ASOCIAȚIA PROMO-LEX (2016) Strategii, practici şi instrumente de finanţare a partidelor politice în Republica Moldova. Chişinău: Asociaţia Promo-Lex. 30 ${ }^{\text {th }}$ March. Available from: https://promolex.md/old/upload/publications/ro/doc_1459254428.pdf [Accessed 08/09/17].

- BOŢAN, I. (2015) Integrarea europeană - ultimul refugiu al ticăloşilor? [Weblog] Analize şi comentarii politice. $1^{\text {st }}$ July. Available from: http://www.edemocracy.md/monitoring/politics/comments/integrarea-europeana-refugiu-ticalosilor/ [Accessed 07/09/17].

- BOŢAN, I. (2016) Partidele şi pendularea geopolitică [Weblog] Analize şi comentarii politice. $\quad 1^{\text {th }} \quad$ November. Available from: http://www.edemocracy.md/monitoring/politics/comments/partide-pendularea-geopolitica/ [Accessed 07/09/17].

- BUCĂTARU, I. (2013) Instituţionalizarea partidelor politice din Republica Moldova: aspecte politico-sociale. In: Academia de Ştiinţe a Moldovei. Revista de filosofie, sociologie şi ştiinţe politice, 162 (2), pp. 55-65. 
- BÜSCHER, K. (2004) Das politische System Moldovas. In: ISMAYR, W. (ed.) Die politischen Systeme Osteuropas. $2^{\text {nd }}$ ed. Opladen: Leske + Budrich, pp. 515-552.

- BÜSCHER, K./ AVRAM, A. (2012) Parteien. In: BOCHMANN, K. et al. (eds.) Die Republik Moldau. Republica Moldova. Ein Handbuch. Leipzig: Leipziger Universitätsverlag, pp. 292-308.

- DELlenbrant, J. A. (1993) Parties and Party Systems in Eastern Europe. In: WHITE, S./ BATT, J./ LEWIS, P.G. (eds.) Developments in East European Politics. London: Pallgrave, pp. 147-162.

- GOŞU, A. (2016) Interview. In: cursdeguvernare.ro [online magazine] $27^{\text {th }}$ April. Available from: http://cursdeguvernare.ro/interviu-armand-gosu-la-chisinau-se-da-olupta-pe-viata-si-pe-moarte-pro-rusul-dodon-are-cele-mai-mari-sanse-sa-ajungapresedinte-in-moldova-ar-trebui-reconstruit-totul-de-la-zero-cu-oameni-noi.html [Accessed 09/09/17].

- IBENSKAS, R./ SIKK, A. (2016) Mergers and splits: How party systems have changed in Central and Eastern Europe since 1990. [Weblog] European Politics and Policy. $3^{\text {rd }}$ October. Available from: http://blogs.lse.ac.uk/europpblog/2016/10/03/party-systemschange-central-eastern-europe-since-1990/ [Accessed 07/09/17].

- INSTITUTUl DE POLITICI PUBLICE (2014) Barometrul Opiniei Publice. Republica Moldova. Octombrie-Noiembrie 2014. Chişinău: IPP. Available from: http://ipp.md/old/public/files/Barometru/Brosura_BOP_11.2015_prima_parte_final.pdf [Accessed 08/09/17].

- INSTITUTUL DE POLITICI PUBLICE (2015a) Barometrul de Opinie Publică. Republica Moldova. Aprilie 2015. Chişinău: IPP. Available from: http://ipp.md/old/public/files/Barometru/BOP_04.2015_prima_parte_finale.pdf [Accessed 08/09/17].

- INSTITUTUl DE POLITICI PUBLICE (2015b) Barometrul Opiniei Publice. Republica Moldova. Noiembrie 2015. Chişinău: IPP. Available from: http://ipp.md/old/public/files/Barometru/Brosura_BOP_11.2015_prima_parte_final.pdf [Accessed 08/09/17].

- INSTITUTUl DE POLITICI PUBLICE (2016a) Barometrul de Opinie Publică. Republica Moldova. Aprilie 2016. Chişinău: IPP. Available from: 
http://ipp.md/old/public/files/Barometru/BOP_04.2016_prima_parte_finale-r.pdf [Accessed 08/09/17].

- INSTITUTUl DE POLITICI PUBLICE (2016b) Barometrul de Opinie Publică. Republica Moldova. Octombrie 2016. Chişinău: IPP. Available from: http://ipp.md/old/public/files/Barometru/BOP_10.2016.pdf [Accessed 08/09/17].

- INSTITUTUL DE POLITICI PUBLICE (2017) Barometrul Opiniei Publice. Republica Moldova. Aprilie 2017. Chişinău: IPP. Available from: http://ipp.md/old/public/files/Barometru/Magenta_BOP_final_v3_27_apr.pptx [Accessed 08/09/17].

- IRMER, S.-J. (2015) Knapper Sieg pro-europäischer Parteien. Kommunalwahlen in der Republik Moldau. [Weblog] KAS-Länderberichte. $16^{\text {th }}$ June. Available from: http://www.kas.de/wf/doc/kas 41723-544-1-30.pdf?150616165828 [Accessed 07/09/17].

- IRMER, S.-J./ AVRAM, A. (2015a) Pro-europäische Parolen und stagnierende Reformen. Neue Regierung in der Republik Moldau. [Weblog] KAS-Länderberichte. $31^{\text {st }}$ July. Available from: http://www.kas.de/wf/doc/kas_42162-544-1-30.pdf?150731150153 [Accessed 08/09/17].

- IRMER, S.-J./ AVRAM, A. (2015b) Herbst der Proteste. [Weblog] KAS-Länderberichte. $17^{\text {th }}$ September. Available from: http://www.kas.de/wf/doc/kas_42552-544-130.pdf?150917115913 [Accessed 08/09/17].

- KESTElOOT, S./ DE VRIES, P./ DE LANDTSHEER, C. (2008) Branding the Mayor: Introducing Political Consumerism in Belgian Municipal Elections. In: LILLEKER, D./ SCULLION, R. (eds.) Voters or Consumers: Imagining the contemporary electorate. Newcastle: Cambridge Scholars Publishing, pp. 73-96.

- NELSON, S. et al. (2010) Moldova Democracy and Governance Assessment. Final Report. Bethesda: Democracy International. Available from: http://democracyinternational.com/media/Moldova\%20Democracy\%20and\%20Governan ce\%20Assessment.pdf [Accessed 07/09/17].

- NEMERENCO, D. (2008) Politics of Transition: A Waste of Votes?. Unpublished thesis (AB), Harvard College. Available from: http://www.ipp.md/old/public/files/Publicatii/2008/Thesis_Final.doc[Accessed 07/09/17]. 
- PARTIDUl ACŢIUNE ŞI SOlIDARITATE (2016) Statutul Partidului Politic "Partidul Acţiune şi Solidaritate” (PAS), Chişinău. Available from: http://www.edemocracy.md/files/parties/pas-statute-2016-ro.pdf [Accessed 08/09/17].

- PISICA, G. (2013) Reflecţii privind sistemul pluripartidist din Republica Moldova. Tyragetia, vol VII [XXII], no. 2, pp. 311-315.

- PROTSYK, O./ BUCĂTARU, I./ VOLENTIR, A. (2008) Competiţia partidelor în Moldova. Ideologie, organizare internă şi abordarea conflictelor etno-teritoriale. Chişinău: CEP USM.

- SIEG, H. M. (2017) Wahlrechtsänderung in der Republik Moldau gegen VenedigKommission und EU verabschiedet. [Weblog] KAS-Länderberichte. 24 ${ }^{\text {th }}$ July. Available from: http://www.kas.de/wf/doc/kas_49655-1522-1-30.pdf?170724123746 [Accessed 07/09/17].

- WEBSTER, J. (2008) Parliamentary majorities and national minorities: Moldova's accommodation of the Gagauz. Unpublished thesis (DPhil), University of Oxford. 


\title{
THE SOCIAL DEMOCRATIC PARTY (PSD) IN ROMANIA WITHIN THE FRAMEWORK OF THE ROMANIAN AND EUROPEAN LEFT. THE PSD MANIFESTO FOR THE 2016 PARLIAMENTARIAN ELECTIONS
}

\author{
Horia-Alin LUPU \\ $\mathrm{PhD}$ candidate, \\ College of Political, Administrative and Communication Sciences (FSPAC), \\ Babes-Bolyai University Cluj-Napoca \\ lupu@fspac.ro, horialupu@yahoo.com
}

DOI:10.24193/OJMNE.2017.23.04

\begin{abstract}
The following contribution aims to shed light upon some facts that can be relevant to the academic field as well as to the practical social/political life, facts related to whether the Romanian Social Democratic Party (Partidul Social Democrat, PSD) properly belongs to the left wing political spectrum in Europe (more precisely to the ideological family of socialists and social-democrats) and also regarding its continuity with the traditional Romanian (interwar period and pre-1918) left. I will review the main theoretical approaches concerning the role and the functions of ideology for political parties and, as a case study, I will analyze the party's political programs and electoral manifestos for the 2016 legislative elections.
\end{abstract}

Keywords: ideology, social-democracy, political party, political program, electoral manifesto.

\section{Introduction}

This article aims to realize a research whose main object is the Social Democratic Party in Romania (PSD), currently the main parliamentary and governing party ${ }^{12}$ (since December 2016 - January 2017), as well as the main national political actor, also taking into account the votes and mandates obtained at the local elections in June, 2016. The main aspects which will be analyzed will be the party ideology, starting with the official documents of the party (political programs and electoral materials/manifestos) used in the electoral campaign of November-December 2016, whose validity was repeatedly reasserted by PSD and its leading staff up to the present. These will be compared mainly with the

\footnotetext{
${ }^{12}$ Forming the coalition cabinet, as major partner, together with the Alliance of Liberals and Democrats Party (ALDE).
} 
Issue no. $23 / 2017$

typical positioning on similar themes of European parties with the same ideological orientation, and colleagues of the PSD in transnational party organizations. Also, in order to properly define de context, I will present aspects linked to the historical evolution of socialism and social-democracy, I will try to synthesize the historical context of the main values and ideological benchmarks of the evolution of the socialist and social-democratic left at an international and European level, including also the main theoretical and methodological approaches regarding the research and measurement of the ideological position of political parties.

After Romania's accession to the European Council (1993) and especially to the European Union (2007), but mainly after PSD's admission to the Socialist International (2003) and later to the Party of European Socialists (2005), the affiliation movement following a similar trend with the majority of "classical" left parties in Central and Eastern Europe, the problem of certain structural, systematical or significant differences between political parties in Western Europe and their equivalents as ideological framing to the East lost most of its significance.

Thus, the series of articles and, later, books, which have Herbert Kitschelt as author/co-author (Kitschelt, 1992; 1995; Kitschelt, Mansfeldova, Markowski, Toka, 1999) suggest the existence of a different ideological placement, perhaps even a radically distinct one, of left and right parties from the countries of the former socialist and soviet bloc compared with their equivalents from the West, depending on the existing types of cleavages in post-communist countries and on the way in which these combine with each other under the pressure from parties and political leaders to mobilize/activate them. The aforementioned events, and especially the affiliation of the majority of East-European parties to international party organization, resulted in a growing pressure toward convergence, at least at the level of doctrines and official political documents.

\section{Terminological specifications}

At the conceptual/terminological level, we can say that nowadays the terms socialism and social-democracy are synonyms (with a touch of complementarity) or functional equivalents. According to various authors, there are several explanations regarding their distinct meanings from the past. Ware (1996, pp. 33-35) mentions two of these. According to the first, we can discuss about social-democracy especially after the left-wing (socialists) parties were contaminated with the economic ideas of John Maynard Keynes around the 
Issue no. 23/2017

Second World War (as an essential turning spot being the Congress of the German Social Democratic Party, SPD from Bad-Godesberg, in 1959), concerning the emphasis upon mixed (market) economy, unlike the previous vision which insisted on socializing/nationalizing the economy and the means of production.

A second distinction mentioned by Ware would be the one of connection (existent or not) between parties and trade unions. Thus, parties which maintained close connections with these (regardless of whether they were actually created by the trade unions or not) would represent the social-democratic type (the classic example of a left-wing political party created by trade unions - British Labor Party - appeared as a result of a motion voted in the year 1900 by the British Trade Union Congress) and those with weak connections with trade unions would represent the socialist type (the case of the French Socialist Party, created in the last quarter of the $19^{\text {th }}$ century by a group of intellectuals and revolutionaries).

In his study (1998, p. 185), A. Carpinschi equates social democracy with "parliamentary socialism" as he suggests that there is a certain closeness to the "revisionism" of the late XIX century (for further details see below) and emphasizing, unlike Ware in the first distinction, two characteristics: the reconciliation of socialism with the liberaldemocratic system and with the capitalist society.

\section{Socialism and social-democracy - elements of history of thinking}

Depending on the authors, one can find the roots of a proto-socialist type of thinking with the classical Greek or late-medieval political thinking, the names that are cited the most being Plato (The Republic) and Thomas Morus (Utopia), according to Ball and Dagger (2000, p. 128). References can also be made to fragments from The New Testament or to the practices of the early Christians from the first centuries A. D., up until the adoption of Christianism as the official religion in the Roman Empire.

However, the true precursors would be those known as the "utopian socialists", category which includes names such as Claude-Henry de Saint-Simon, Auguste Compte (founder and supporter of positivism or "social physics", as he intended to call what we label nowadays "social science"), Charles Fourrier and Robert Owen (Ball, Dagger, 2000, pp. 130132). Despite the differences among them, these socialists were the exponents of a certain Enlightenment-type, planning oriented maximalism, critics of capitalism as a generator of excessive selfishness and waste, unscientific and encouraging immoral educational models. The suggested solutions, be it at a macro-theoretical level or at micro-applicative one 
Issue no. $23 / 2017$

emphasized the communitarian side of human nature and the importance of the interaction between individuals, the use of scientific knowledge and expertise, the power of motivation and the role of education in the success and development of communities and society.

The socialist thinking that we know today was to be truly structured in the post-Hegel period, its ideas being laid down by Karl Marx and Friederich Engels. The process that Marx started and which he continued together with his co-author, Engels, was extensive, systematic and claimed a scientific nature for itself (a claim underscored after Marx death).

One of the defining elements of Marxism would be the takeover and development of the G. W. F. Hegel dialectic vision of history, in which the relevant advancement is preceded by the ruptures/alienations, expressed through the thesis/antithesis conflict and the advent of progress through synthesis (Hegel, 2000/1807). Another would be the collective and communitarian perspective over society and individuals, the social class and membership to it having a decisive relevance for one's identity. The "engine" of history for Marx and Engels is represented by the fight for survival and for progress of the individuals/communities, through a combination of evolution and conflicts in which the class struggle (and the exploitation that comes with it, generated by the type of relation with the means of production) is essential. Those who possess, master and control the means of production are the ones who will control the power in society (political power included, political institutions being subordinated and functionally dependent on the economy; the same thing with the ideology - the prevalent pattern of thought from/about society, which generates a "false consciousness" of those who are exploited). Those who are reduced by the need of survival/economic gain to the state of being associated with them (slaves, peasants, proletarians/workers) are subjected to exploitation (Ball, Dagger, 2000, pp. 132-147).

Unlike utopian socialists, for Marx and Engels exploitation has a systematic character rather than a moral one. In capitalism, the only freedom that exist belongs to the capital (and not to the entrepreneur), this reality is what generates alienation; the capitalist himself is forced to obey to the logic of its functionality (Marx, Engels, 1962/1848). At the foundation of exploitation and the class struggled lies the private propriety and its emergence (Marx, Engels, 1956/1845).

At the core of the class struggle is the struggle of the other social classes to take the place of the exploiting class, and this mechanism seems to be unstoppable. The takeover of power by the working class should end this race and the internal contradictions accumulated by capitalism. This working class, which is a "the universal class" has as a purpose its own 
Issue no. $23 / 2017$

abolition and the end of exploitation. This would lead (with an intermezzo of "the dictatorship of the proletarians", destined to consolidate the temporary control of the working class over the state and society) to the dissolution, in an undefined interval, of the private propriety, of the state, even of the process of labor as known by us, and to a society that was forecasted as open/democratic (Ball, Dagger, 2000, pp. 132-147).

Another important trend in the structuring and evolution of socialist thought and doctrine was the revisionism, which emerged mostly after the death of Marx (1883) and Engels (1895). Its main exponent, Eduard Bernstein, in his work Evolutionary Socialism stresses the progresses achieved in a rather short period of time, by the socialist and tradeunion movement from Germany thus invalidating Marx's predictions that "the rich are going to be richer, and the poor will became poorer". He opposes, due to moral reasons (invoking Kant) a bloody revolution and the dictatorship of the proletariat, supporting the immediate interests of the working class and advocates for the constant and gradual improvement of these through political and social actions in a democratic environment (Berstein, 1907/1899; Ball, Dagger, 2000, pp. 154-155).

The last author I will mention, Vladimir Ilich Ulyanov (Lenin), is a critic of revisionism (considering it as collaborating with the bourgeoisie) and is the one who moves on from the socialist/social democratic way of thinking to communism. Alongside radicalization of ideas - the critique brought to "parliamentary-socialism", trade unions and Western working class for the false consciousness induced by the capitalists and the apologetic stance towards the revolutionary avantgarde/avantgarde party and of the democratic centralism (Ball, Dagger, 2000, pp. 156-159) - the latter making possible for the authoritarian/totalitarian party and rule to emerge, Lenin contributes to the development of leftist ideas by introducing and defining the concept of imperialism (Lenin, Imperialism, the most advanced stage of capitalism, 1916). In this work, who's topics are still being reused in different political and ideological contexts even to this day, Lenin upholds that the progress of developed societies (which already are in the imperialist stage) is based on the exploitation of underdeveloped nations and by doing so, the members of the advanced nations benefit from that in integrality (even if in different degrees, taking into account their social class). Therefore, the emergence of the socialist revolutions in the exploited societies is justified. 
Issue no. $23 / 2017$

\section{The institutional history of socialism and social democracy in Europe}

Since their birth, in the second half of the XIX ${ }^{\text {th }}$ century, the socialist and socialdemocratic parties had two main objectives: to obtain political rights for the working class (the - at least male - universal suffrage) and, together with the trade unions, to provision social and economic rights (labor related) for them (Gallager, Laver, Mair, 2002, p. 204). Evolving together reunited in the Second Socialist International (1889-1914), which has served them as a debate forum among Marxists and revisionists (later, after 1905, the Bolsheviks enter the scene too) as well as an umbrella for different existing currents orthodox revolutionary Marxism, anarchism, revisionism, social evolutive fabianism and Leninism (Carpinschi, 1998, p. 176). A common and constant trait of this period is how important the shared perception over the importance of internationalism, which supports the transnational interests of the workers (the exploited class) in their fight against the exploitation represented by the global capitalism.

An example of success for this period, in spite of an official interdiction between 1878 and 1890, was the German Social-Democratic Party (SPD). During the first decades of the $\mathrm{XX}^{\text {th }}$ century, this party, which was organized as a mass party, had more than 1 million members, a budget of 5 million Reichmarks, its own media, a central school in Berlin for the education of the workers elite and an umbrella of associations (of judicial/legal assistance, educational, cultural, sportive and recreational) developed around the party and the trade unions. In 1912, as number MPs, SPD became the most important party in the Reichstag.

Therefore, at the organizational level, we have what Maurice Duverger calls a typical mass party, with ramification over the territory, with constant activities at the subsidiaries level (the branches of the party), ideologically structured and democratically financed, in which the power is held by the formally (and, at least theoretically speaking, democratically) chosen leadership of the party and not by an informal elite represented by MPs (Carpinschi, 1998, p. 176). The efficiency of the SPD is proven by the improvement of the situation of the socio-political rights as well as the economic conditions of the German working class until the start of the First World War, although the party remains what Sigismund Neumann calls "the party of social integration", making it easier way for the integration of the working class in a social and cultural web which engulfs them, as the author says, "from the cradle to the grave" (Neumann, 1956, p. 47). But the political integration, in spite of the progresses made, was not possible. The other parties and political forces united against the socialists/socialdemocrats due to the perception of a threat which the socialists could pose to the system 
Issue no. 23/2017

itself. This reality is more or less characteristic for all the European states where such movements existed.

The following event in the evolution of socialist and social-democratic parties is the First World War, with the blow given by it to internationalism (most of the socialist representatives in the European legislatives voted in favor of military expenditures of their nations, involved in a "capitalist war") and connected with it but far more important, the Russian October Revolution of 1917 (Ware, 1996, p. 34). Following this stage, most of the radical leftists of the socialist parties and social democratic movements break up with them, creating communist parties; The Third (Communist) International is founded in 1919.

During the interwar period, in spite of the fact that the (male) universal suffrage already existed in Europe (partly due to their pressure), the socialist parties are marginal as a political influence ("victims of their own success" in mobilizing the working class electorate, as mentioned above and underlined by Kirchheimer, 1966). Their access to government is limited (Sweden being an exception), as well as the capacity to influence the society through public politics.

The real opening into activity of these parties appears only after the Second World War. From the end of the 1940's and all the way to today, with certain fluctuations in time and differences from nation to nation, socialists and social-democrats become, on the electoral results level, one of the two main political families in Europe (Gallagher, Laver, Mair, 2002, p. 206) alongside and in competition also with the popular parties (conservatives and Christian-democrats). Creators and supporters of the welfare state, moderate and constant promoters of European integration (in ECCS, EEC, EC and EU), the representatives of this ideological line of thought gave up their Marxist inheritance. Two main events mark these process: The First Congress of the Socialist International in Frankfurt am Main (1951) and, most important, the Congress of the German Social-Democratic Party in Bad-Godesberg (1959). Within these events the support for democratic organization of the society and the option for a mixed economy is asserted (Carpinschi, 1998, pp. 187, 190).

From an organisational point of view, the transition from a mass party to a catch-all party is made. Its five characteristics (stated by Otto Kirchheimer) are the following: 1) drastic reduction of the party's ideological baggage; 2) the growing in importance of leaders; 3) the loss of the importance of the individual members; 4) and of what the author calls "classe-gardée" (a social class towards which the political message is specifically directed); 
5) securing access to a variety of interest groups for financial and electoral reasons (Kirchheimer, 1966, p. 190).

The '60s bring the appearance of the New Left (feminist, antiwar) and a new type of competition to the left of social-democracy, amplified in the 1980-1990 by the emergence of the Green parties (Gallagher, Laver, Mair, 2002, pp. 203; 209-211). The 8th decade, starting with the oil crisis from 1973 (along with its cumulated economic effects) and also the rise of the New Right will lead to a shift towards the center of the social-democratic parties, with a reduced accent on the role of the state in the economy. This shift appears to be countered, in recent years, by a mobilization of the left against the austerity policies promoted by the right as a reaction to the financial crisis which started in 2008 .

\section{Ideological and institutional milestones in the evolution of the Romanian social-} democracy

In the Romanian space an arguably early emergence of socialist (utopic) inspired ideas, and even an attempt, with no real success, to put them into practice can be spotted in mid-1830. This happens in the form of the phalanstère/phalanstery (association/community working under cooperative principles) established at Scaieni (Prahova) by Teodor Diamant, a disciple of Charles Fourier, following his ideas, after he came back from France.

The economic and social context remains unfavorable for the development of these ideas and organizations, due to the industrial underdevelopment of the Romanian Principalities, and latter (from 1881) of the Romanian Kingdom (Proca, 2010, pp. 24-25) with the exception of some urban centers in Transylvania, Banat or Bukovina, which up until 1918 were part of the Hapsburg Empire. Within them, the (Romanian) socialist movement (in parallel with the other nations within the Empire) was much stronger than the one in the Old Kingdom. In the beginning of the $\mathrm{XX}^{\text {th }}$ century, figures like Iosif Jumanca and Ion Flueraș were some of the most well-known leaders of the Romanian socialists from the AustroHungarian Empire.

For this reason in the first Romanian socialist program $(1886-$ Ce vor socialiștii români?/What do the Romanian Socialists Want?), preceding and contributing to the subsequent structuring of the first Social Democrat Party in the Kingdom), the author, Constantin Dobrogeanu-Gherea, feels the need to justify, in a full chapter, the necessity of the appearance of socialism in the Romania. Although we can find Marxist influences in his 
program, he also writes about the topic of the development gap between the West and Romania, imposing an approach close to the revisionist one (Proca, 2010, pp. 26-27).

The Romanian Social Democratic Workers Party (PSDMR), which appeared in 1893, maintains the same moderate and "legalistic" orientation. It is established and animated by a series of intellectuals (Ioan Nadejde, Vasile Morţun, Sofia Nădejde, Traian Demetrescu, Constantin Stere, Anton Bacalbașa, along with C. Dobrogeanu-Gherea) and coexists with the trade union movement (professional workers' associations), instead of being founded on their initiative. The party accedes to the Parliament with several elected representatives and is abolished in 1899 by an episode called "the betrayal of the generous" in the epoch - the passing of a significant number of leaders to the National Liberal Party, PNL (Proca, 2010, pp. 28-29).

Beyond its direct political impact, which was limited, its importance can be put into perspective through its role in introducing into the public/parliamentary debate in Romania of some themes that were specific to socialism (universal suffrage, social/labor related rights and legislation, women's rights and emancipation) and through its indirect influence on two contemporary doctrines that came about at the end of the XIX ${ }^{\text {th }}$ century, poporanism and sămănătorism (Jurcă, 1994).

The party is rebuilt in 1910 as the Social Democratic Party (PSDR), from December 1918 the Socialist Party of Romania. Ion C. Frimu, Mihai Gh. Bujor, Christian Racovski, Dimitrie Marinescu and Constantin Vasilescu are among its leaders. The party's ideological orientation is initially moderate, following PSDMR's tradition, but it then goes through an extensive period of internal strife and organizational transformation after the Russian Revolution and the First World War/The Great Union (1918). Afterwards, in 1921 the communist faction takes the lead and the figureheads of the moderate groups are kicked out of the party, which then becomes the Romanian Communist Party (PCR). Organizationally, a social-democratic party (PSD) will be reestablished, following many phases, only in 1927 (Proca, 2010, p. 37). It will have Constantin-Titel Petrescu as its leader until its disappearance in the post-World War Two period.

Although in Romania universal male suffrage is introduced (1919), with the exception of the first organized elections, the scores obtained by the socialists/social-democrats remain insignificant. The immediate causes were tied in to the antisocialist legislation of some governments, to internal fragmentation and, in a smaller measure, to the competition represented by the radicals of PCR, a party which was legally banned immediately after its 
Issue no. $23 / 2017$

founding. The structural causes remained those of a still incipient industrialization of the country, despite some visible progress that came after 1918. But there was another socioeconomic characteristic that, if identified adequately, could have opened the way for a socialist/social-democrat message in the Romanian society. This was represented by two components: the predominance of manual labor in all three sectors of the economy and the existence of a large category (in industry, but especially in agriculture, services) without private property/ with insufficient property, ineligible for the middle class and, as a result, mostly able to be assimilated with the proletariat.

In parallel with PSD, PCR remains irrelevant when it comes to the number of members and sympathizers, being controlled, through the Comintern and the Soviet Union's Communist Party, by power structures (political and informative/espionage) from within the totalitarian soviet state, which did not officially recognize the territorial integrity of the Kingdom of Romania after 1918.

After the $23^{\text {rd }}$ of August 1944 and the shift of the PCR from illegality straight to governmental power, in the context of the soviet armies entering the Romanian territory, PSD comes to the forefront within the national unionistic government. The broader association of the two parties (PCR and PSD) will continue in 1946 through a forced alliance (rejected by a part of the PSD leadership, which tries to establish a new party) and through a forced absorption into PCR in 1948, the new party being renamed to the Romanian Workers Party (PMR). Symptomatically, the former leader of PSD, Constantin-Titel Petrescu, is politically convicted by the new communist regime, is released and ends his life in hospital as a result of the harsh treatment suffered in detention.

Post 1989, Romanian social-democracy remained divided and made up of competing parties until 2005. For the most part of this period there were three political parties whose interaction was determined, first and foremost, by the way in which each one of them related to the communism/neocommunism - anticommunism cleavage.

The most important one, the National Salvation Front (FSN), predecessor of the actual PSD, is the result of the transformation of the temporary organization of the revolutionary power from December 1989 into a party, at the beginning of 1990. Although often accused by rival formations of neocommunism, it should be mentioned that FSN was not a proper successor party, PCR being outlawed and dissolved after the $22^{\text {nd }}$ of December 1989.

Chronologically, its first opponent was the Romanian Social Democratic Party (PSDR), (re)founded at the beginning of 1990 by veterans of the interwar PSD, from where 
Issue no. $23 / 2017$

they reclaimed their continuity and legitimacy. PSDR had a manifest anticommunist orientation and joined in 1992 the Romanian Democratic Convention (CDR), a grouping of right-wing opposition parties mobilized against FSN. The situation gets further complicated starting from 1992 with the schism of FSN between Petre Roman's wing (former primeminister, perceived as being more liberal) which remains in, and takes control of the party (that at a later date becomes the Democratic Party, PD), and the majority grouped around Ion Iliescu (president-in-office), who will form a new party, the Democratic National Salvation Front, FDSN (which later changed its name into the Party of Social Democracy of Romania, PDSR).

In 1995 PD and PSDR will ally themselves in view of the elections of the following year, forming the Social-Democratic Union (USD). This alliance represents PD's access key the Socialist International, in 1996. In the same year, USD participated (as a minor partner) in the forming of the government after the elections, together with CDR and the Democratic Union of Hungarians from Romania (UDMR).

In the year 2000, PDSR and PSDR will set up an alliance, forming the SocialDemocratic Pole together with the Romanian Humanist Party (PUR). In the following year, the two parties will fuse together and PSDR (ex-FDSN, ex-FSN) becomes PSD. The absorption of PSDR will grant its access to Socialist International. The Democratic Party (PD) leaves the International, in 2005, and after its subsequent repositioning on the right (together with its affiliation with the European People's Party) ${ }^{13}$, PSD remains the sole force of the Romanian left. ${ }^{14}$

\section{The spatial approach and the institutional approach}

Even assuming that the acquiring the political power is the principal and most defining aim and trait of a political party (as authors like M. Duverger, A. Downs, G. Sartori and K. Janda do, in their definitions), it is hard to imagine today a party without an ideology. As "filters"/"gatekeepers" of the political system, and mediators between it, the state and the society/voters, the ideology fixes an identity, be it even relative and in constant change, in whose absence parties would find it very difficult to carry out any type of functions, be they

\footnotetext{
${ }^{13}$ At the end of 2014, PD (which meanwhile became the Liberal-Democratic Party, PDL) fused with PNL, under the name of the National Liberal Party.

${ }^{14}$ In the end of this section I used data from Stoica (2004)
} 
vote-seeker, policy-seeker or office-seeker. ${ }^{15}$ Ideology represents „the public face” of a party, what it wants to say about itself (Ware, 1996, p. 20). According to the same author (Ware, 1996, pp. 18-14) there are two types of approaches which can be used to explain the way in which the political parties relates to ideologies, the spatial and the institutional.

The spatial or the competitional approach stems from the assumption of the existence of a political space/continuum, in which parties and voters are self-aware and rational actors, that pursue their own interests (parties, in essence, obtaining votes to acquire power, and the electorate voting for a party that is closest to their positioning). This approach was inspired by authors such as the economist H. Hotelling (and his spatial representation of economic competition) and the creators of the rational choice theory (RCT) - especially Anthony Downs in his "Economic Theory of Democracy" (1957).

There were three types of problems identified in the case of the spatial representation approach, in spite of its obvious conceptual clarity. First and foremost, Downs was suggesting the existence of one continuum only, one space (left-right), a fact that was being questioned by other scholars who supported the rational choice theory. Therefore, authors like Ian Budge or David Robertson, back in the 70's, wondered if there only had to be one axis and not distinct ones (political, economic, social) on which the political parties' views could be represented, and also if those positions would be coherent enough with each other to give a specific identity to a party (Budge, 2006; Ware, 1996, p. 20). An additional challenge is positioning ideologies that are not usually imagined in left-right terms on a left-right axis (nationalism-antinationalism, environmentalism or green and antienvironmentalism, feminism etc.).

A second issue identified was generated by the question: "What are the elements that compose the ideological profile of a party?" Besides the doctrine, meaning documents and electoral manifestos (what a party promises it's going to do), there is an even more abstract and harder to define element - the ethos, which is, according to H.M. Drucker - "what in the past we'd call the spirit of a party, its traditions, rituals and the way it is being perceived" (Ware, 1996, pp. 20-21). Thus, according to Drucker, the ideology of a party also embraces, alongside doctrine, its ethos. Public policies (initiated, adopted, implemented by central or local political institutions, representing what a party does (and arguably more importantly

\footnotetext{
${ }^{15}$ In the Romanian politics, the recent difficulties experienced by the Save Romania Union (USR), a party newly-founded before the legislative elections of December 2016, due to the absence of a clear positioning with regards to controversial themes in public debate seem to confirm this vision.
} 
Issue no. 23/2017

than what a party says it would do), are also very important when analyzing the ideological engagement of a party. We can also mention the declarations and speeches of political leaders, either official ones or publicized by the media.

The third and last issue represents the existence of populism either at the party (with some possible emphasis on new parties) or at the political system level (with some tradition in Latin America or South-East Europe, according to Ware, 1996, p. 21). In this sort of context, the parties which access to power seems to be blocked tend to show irresponsibility in terms of policy proposals, starting what G. Sartori calls, "the politics of overbidding" among themselves (Sartori, 2012, pp. 147-149). Another possibly trouble making issue could be the existence of factionalism, in terms of different ideological affiliations within the same party (see the case of the Democratic Union of Hungarians in Romania - UDMR, according to some sources and observers - even if this could also function as a counterexample).

The institutional or historical approach underlines in essence the fact that, although parties (through their leaders or management board) can act as rational entrepreneurs in search for gains on the political market, they are not fully free agents. For every party its history as an institution matters, and its actions in the present are, at least partly, conditioned by it. Furthermore, parties which, in different countries, have mobilized a similar electorate and have supported similar ideas and programs will have a sum of common elements (Ware, 1996, pp. 21-22; Gallagher, Laver, Mair, 2002, p. 202).

The author which developed the most used typology of parties in accordance with their ideology and their political and institutional history is Klaus von Beyme. He uses the phrase "familles spirituelles"/"spiritual families" for the ideological families of parties. By using the political context of the European liberal democracies he identifies nine such families (von Beyme, 1985, in Ware, 1996, p. 22), in the chronological order of their appearance:

1) Liberal and radical parties

2) Conservative parties

3) Socialist and social-democratic parties

4) Christian-democratic parties

5) Communist parties

6) Agrarian parties

7) Regional and ethnic parties 
Issue no. $23 / 2017$

8) Right and extremist parties

9) The ecological movement

Gallagher, Laver and Mair (2002, p. 203) have a similar approach, dividing political families in families of the left (social-democrats, communists, the new left, green parties) and families of center and right (Christian-democrats, conservatives, liberals, agrarians or center parties and extreme right parties). It can be noticed that there are also nine categories; if among the families of the left we have an extra-family of the new left, from those of the center and right we lack the ethnical and regional parties.

\section{The analysis of the PSD programs. The legislative elections of December 2016 Introduction}

Concerning a distinct (and partially divergent) alignment of the Social Democratic Party (PSD) with the mainstream Western European left, several explanations and arguments have been advanced during the early '90s. Kitschelt (1992; as well as is in Lupu, 2017, p. IV) spoke of an alignment of the Eastern European left-wing successor parties (with which PSD could be associated with) to the left on the axis of controlled economy - market economy, and to the right on the axis of libertarianism - authoritarianism, in order for them to preserve the advantages of the status-qvo.

Alternatively, due to the presence of this successor type of left-wing parties in the government immediate after the fall of communism (the specific examples being Romania and Bulgaria, unlike in the other countries from the former Socialist block), the initial phases of the controversial privatization of the hyper-centralized socialist economy fell in their responsibility (Lupu, 2017, p. IV). That represented a dual contamination source, leading to the development of privatization programs by these parties (which had in their ranks leaders with "an obvious entrepreneurial profile") as well as to a slower process of privatization. To all of these, we can add up, as Daniel Seiler says (1999), that the specific reality of the area generates a cleavage among communists (neo-communists) - anti-communists (democrats) which goes past the classical cleavages of Rokkan and influences the layout of the left-right axis. What will be directly affected is the Romanian socialist/social-democratic movement, which at first is not perceived as such; in the first decade post-1989, the historical Romanian Social Democratic Party, PSDR is in opposition (and even member in adverse, right-leaning political alliances) towards the National Salvation Front (FSN), the National Democratic Salvation Front (FDSN) and the Party of Social Democracy of Romania (PDSR). 
Issue no. $23 / 2017$

Subsequently the National Salvation Front, FSN (who later became the Democratic Party, PD) has followed a similar oppositional path related to the National Democratic Salvation Front/the Party of Social Democracy of Romania (FDSN/PDSR), party from which it got separated.

Secondly, and conjunctively with the initiatives and attempts of the FDSN/PDSR to find legitimization in the field of the international affiliations (The Socialist International and the European Socialists), this type of cleavage has also generated joint efforts of the party to drop the totalitarian communist heritage ascribed to it, eventually calling for - starting with the leader of the party Ion Iliescu (currently honorary president) - a revolutionary legitimacy from the events leading to the overthrow of the totalitarian communist regime in December 1989.

Even after the adherence of the party to the Socialist International and to the European Socialists Party (in 2003 and 2005), we can still notice, in their programs, as well as in the public policies promoted by the Social Democratic Party (PSD) some particularities which cannot be found within the European social-democracy. During Ponta $3^{\text {rd }}$ and $4^{\text {th }}$ cabinets (after the break-up of the Social Liberal Union, USL: March 2014 - November 2015), although at that time the program of the PSD included progressive taxation, the Prime Minister Ponta kept using, even after the exit of The National Liberal Party (PNL) from the Social Liberal Union (USL), the minimal/flat taxation (16\%) on profits and incomes, highlighting its positive effects on the economy.

Also the messages coming from then-presidential candidate Victor Ponta during his electoral campaign for the presidential elections of November 2014 - having Victor Ponta as Prime Minister and President of the PSD as well as the adversary of the liberal (PNL) presidential candidate Klaus Iohannis - upholding his beliefs in the merits of the ethnic and confessional particularism (Romanian and Orthodox) against an opponent of German ethnicity and Evangelical denomination - proved to be peculiar, from the point of view of the laïcité (if not the anticlericalism), the universalism and multiculturalism the European Socialists were promoting for years. We can also remember one of his campaign slogans: "Proud to be Romanians".

\section{Romanian Social-Democratic Party's Political programs and manifestos}

In analyzing the political programs with whom the PSD presented itself to the electorate during the November 2016 campaign and the elections that followed in December, 
a heuristic distinction between political programs and electoral manifestoes can be made. The first state positions in terms of values and include generic measures (without a time limit in which these measures must be applied) and the latter contain concrete measures and public policies proposals.

The approach used in this analysis is a spatial-institutional one, using the left-right axis and the characteristics of the social-democratic or socialist party family as a benchmark in order to fit the proposed values and measures from PSD political documents. The qualitative-discursive method used by the author is based upon his experience as an expert in encoding the political programs of Romanian political parties between 2014 and 2016 as part of the "My Vote" project ("My Vote" is a collective academic project with researchers from the University of Zurich, the eDemocracy center, the ZDA and from the Centre for the Study of Democracy, part of the Political Science Department the Babes-Bolyai University (http://www.votulmeu. com/\#!/articles/public/About ).

\section{The political program of the PSD}

The programmatic minimalism shown by all the political parties during the $2016^{16}$ legislative elections is also present on PSD's website (www.psd.ro) where the information are presented in a general manner. The PDS legitimizes itself („Cine suntem?”/ "Who we are?” http://www.psd.ro/despre/cine-suntem) through the economic growth and an increase of the average Romanians' living standards ("party of welfare") and with its role in getting Romania to be part of NATO and the EU. Another source of legitimacy can be the PSD's allegiance to the Socialist International and membership of the European Socialist Parties. The importance of political parties for the well-being of representative democracy is also mentioned.

A true political Decalogue is present in the section „În ce credem“/ "In what we believe" (http://www.psd.ro/despre/in-ce-credem):

1. We believe in the equality of chances

2. We believe in the values of democracy, the right to private property, we believe in each Romanian and in Romania

3. We believe in state-funded education

4. We believe in state-funded healthcare

\footnotetext{
${ }^{16}$ Maybe, paradoxically, with the exception of Popular Movement Party, PMP (Lupu, 2007, p. V) - https:// pmponline.ro/program
} 
Issue no. 23/2017

5. We want a system of progressive taxation in order to reduce social cleavages

6. We want the workers to have minimum conditions by law: minimum wage, protection against abusive dismissal, paid leave etc.

7. We believe that social responsibility is not a charity, but an expression of solidarity between humans

8. We believe that the environment is something that we must leave for the future generations, thus its protection is an important objective

9. We believe that there is a need for ethical and fair trade, based on dialogue and transparency as an alternative to the liberal principle of free trade 10. We believe in multiculturalism and gender equality

These points shape a social-democratic vision of the society, according to PSD. Worth noting is the reference to the right to private property, possibly as a counter reaction to the fact that many voices have accused the PSD of communism, also the mentioning of statefunded healthcare and education, of a system of progressive taxation and (as a novelty) the idea of ethical trade. There are also some elements of the new left present: multiculturalism, gender equality and environmentalism

The section "Politica PSD"/ "PSD politics and policies" (http://www.psd.ro/\%20viziune/ politica-psd) targets the electorate of the party. This is not the "proletariat/working class" (less numerous and harder to define nowadays), but "the many" ("the common people", "those who work", those employed in commerce and state funded sectors such as education and healthcare). At the end of the paragraph there's a mention of the entrepreneurs, as well as the big and small businessmen.

The last reference is not regarding to class but communities and the importance of politics in these communities, an approach that can go with the principle of subsidiarity (ideologically originating in Christian-democracy and Conservatism) as well as with the idea of "grassroots involvement" promoted by the new left. The section ends with a message to Romanians who live and work outside Romania, calling them "the country's most important creditors" - probably the most important reference to them from any political party in Romania. ${ }^{17}$

In the other two sections, the emphasis is put on the party's need for openness:

\footnotetext{
17 A most surprising aspect, considering PSD's (and its cabinet's) attitude towards the Romanian voters from abroad, during 2014
} presidential elections. 
Issue no. $23 / 2017$

towards its own members, who are "neither barons ${ }^{18}$, nor corrupts or communists", through internal democracy and their mobilization as human resource (a typical step, we could say, for a mass party belonging to M. Duverger's typologies), towards society/supporters, enhancing the need to create/restore bridges of connection with intellectuals and towards specialists and experts (in the first, http://new.psd.ro/viziune/psd-in-2016 ) and the need to recognize and repair mistakes from the past in the second ( http://new.psd.ro/viziune/psd-isiasuma-trecutul ). Among these, it is mentioned the conviction of communism and the 1990 "University Square" episode, as well as the restoration of the relationship between the party and the Transylvanian electorate. Having in mind the need to avoid "post hoc, propter hoc" reasoning, we can ask ourselves how many of the changes occurred in the sociodemographic profile of the "typical PSD voter" or how much of the electoral score without precedent obtained by the PSD in Transylvania could have been generated by these messages.

The last section to which I am going to discuss about in this part of the article is the most ample of the mentioned ones, and comes as a completion to the 10 points (,În ce credem?"/ "In what we believe?") in order to create the imagine of what could be called a project/vision of country (http://www.psd.ro/viziune/proiectele-psd ). There are many outlined aspects and the approach is one specific to a "catch-all" of party: the need of trust, decentralization, constitutional reform, durable development, a socially active rule of law with powerful institutions. As novel themes for a social-democratic party, we can mention the outlined need to support the Romanian entrepreneurs (in a context dominated by multinational corporations), the importance of national defense (the allocation of $2 \%$ from GDP for defense being the only specific provision from what we could call the "political program" part), the need for diminishing the bureaucracy and the support for the reconstruction of the media/printed press. Finally, it emphasizes the need for a medium-long term development plan for Romania (25 years), which needs to be debated with the Romanian Academy, the society and all political forces.

\section{Electoral manifestos}

These consists of a series of seven sets of documents which contain extensive measures for the modernization of society and the improvement of life standards (justified mainly in terms of general utility rather than from an ideological perspective - again, a catch${ }^{18}$ A term used by the Romanian media and politicians, referring to the powerful (and allegedly corrupt) local political leaders, in analogy
with the power of the feudal barons. 
all party trait) accompanied by a corollary present in the beginning of almost every section: "more Romanians in the middle class"19. This main preoccupation, together with the program of financial support provided by the state for the young entrepreneurs' business start-up projects (one of the first public policy introduced by the PSD government in 2017, after winning the elections) and the maintenance of the flat taxation (16\%) for profit (in contradiction with what is stipulated in the political program part concerning proportional taxation - http://new.psd.ro/despre/in-ce-credem), along with numerous tax exemptions for various categories of citizens marks an obvious shift towards right. The only provided limitation concerning this aspect is the one on outsourcing the profit of multinational companies, to be applied starting with 2018.

Modernization proposals regard the development of road, railway and airport infrastructure, reindustrialization (with the support of the Sovereign Development and Investment Fund, FSDI, whose establishment is envisaged, and through the use of European funds, http://psd.ro/assets/pdf/Programul\%20economic\%20al\%20PSD\%20\%2022.09.2016.pdf) reducing bureaucracy, investments in health services (construction of a republican hospital and 8 regional hospitals until 2020, supporting the national pharmaceutical company, equipping county hospitals, supporting family doctors, new public health programs, prevention programs, http://www.psd.ro/assets/pdf/Programul_PSD_pentru_Sanatate_-04.11_.2016_pdf), in education/for the use of young people (development of the educational and sport infrastructure, $\quad$ http://psd.ro/assets/pdf/Programul_PSD_pentru_Tineri_si_Sport__07.11_2016_.pdf) and in agriculture (extension of irrigation systems, development of antihailing and rainfall enhancing systems, initiation of a national research \& development system, $\quad$ http://psd.ro/assets/pdf/ Programul_PSD_pentru_agricultura__28.10_2016_(1)_.pdf).

Beyond these investment and actual modernization proposed programs, one of the most important characteristics of electoral manifestos of the PSD is the encouragement for development through financial facilities and incentives, in multiple and various fields of activity, in the shape of exceptions and reductions (temporarily or permanent) of taxes and contributions. The basic tax thus remains at $16 \%$, but is reduced for small enterprises, and

\footnotetext{
19 "PSD's objective is that each and every Romanian who works hard, contributes and has contributed to the economic growth, is part of the middle class" (Liviu Dragnea, "The development and modernization of Romania", http://psd.ro/assets/pdf/Dezvoltarea_si_ modernizarea_Romaniei_-_Romania_start-up.pdf, p. 10
} 
Issue no. $23 / 2017$

there is also a proposition for non-fiscal taxes to be removed. Tax cuts have a special section dedicated to it: http://psd.ro/assets/pdf/Programul_economic_al_PSD_(partea_a_11-a)__09.10_.2016_.pdf.

We can see here a clear distinction with the solidarity principle, usually used by socialists and social-democrats through progressive taxation (thus increasing the amount of collected money) to support a high social and economic involvement of the state in order to help the disadvantaged and to support the progress of society. Another specific note is the assumed national character of some measures, such as supporting local investors in an environment dominated by multi-national corporations or supporting Romanian farmers on the European market.

Another striking dimension of these electoral manifestos is comprised of the measures that aim to raise the income/standard of living for almost all socio-professional classes. Thus it proposes an income tax cut from $16 \%$ to $10 \%$ (and an full exemption for medical doctors, IT-related jobs and anybody with an income below 2,000 RON gross/month), tax cuts for social security and medical insurance, cuts or removal of the income tax and health insurance tax for retirees (according to the level of the pension), tax cuts or exemptions for dividends, property or land transfer. ${ }^{20}$

The proposed effective growth measures proposed refer to a $40 \%$ minimum wage raise, a $56 \%$ minimum wage raise for state employees, a $60 \%$ raise in the pension point and minimum-guaranteed pension, credits of up to 40.000 lei with state subsidized interest for young people and, in effect, the doubling of the income for medics and nurses. As means to support the additional incomes the following are mentioned: the multiplication effect of income raises and investments done through the Sovereign Investment and Development Fund (FSDI), increased tax collection, absorption of European funds and taxes (limiting the externalization of profit) on multinationals. The concrete/detailed way in which the FSDI is to be capitalized, beyond the issuing bonds and providing dividends, is not specified.

In comparison to these measures targeted at a micro or medio-societal level, the more complex and ambitious plans of development - a trademark of the classical socialism and social-democracy, and which are also a part of PSD programs - seem to occupy a second place. We are talking about goals such as reducing unemployment (below 3,5\%) and creating

\footnotetext{
${ }^{20}$ Though the majority of these measures have a deadline on $1^{\text {st }}$ January 2018, they were put on hold by the debates on topics (not mentioned in the electoral manifestos) such as global household tax or the passing of the tax-paying duty from the employer to the employee, which animated the PSD governments in 2017. Not to mention the episode of the pardon and amnesty provided in the "famous" OUG (Government Emergency Ordinance) 13, issued at the beginning of the year.
} 
Issue no. $23 / 2017$

850.000 jobs before 2020, reducing the risk of poverty and social exclusion for 1.500 .000 people and increasing salaries to over 1000 euros for at least 1000000 people in the same year horizon. Furthermore, the plan to move to an economy based on innovation and the advancement of the country to the $13^{\text {th }}$ place as an economic power in Europe (from the $17^{\text {th }}$ ) are also being considered.

\section{Conclusions}

This article presents two directions of evolution considered by many to be distinct/divided - that of the noncommunist, Romanian left-wing (socialist, social-democratic - "democratic" being used here in order to signal the compatibility with the democratic political system) organized thinking and politics, along the history, on the one hand, and that of the nowadays Romanian Social Democratic Party (PSD) on the other. The first one starts developing in an atypical economic and social background, dominated by agrarian and landed economic interests and by development gaps which apparently have no connection to the industrial economy (or generated precisely by its insufficiency) and then it continues with organizational splits and realignments of exponential figures only to be dismantled too fast under the pressure of a communist totalitarian system.

The second one starts its existence in a particular way as well - neither as a successor party nor as a promoter of interwar socialism, but rather as an expression of a communist, clandestine, uncertain reformism. Left-wing party and partially "condemned" to right-wing policies (privatization), with internal struggles and involvement in dark and controversial historical episodes (Mineriadele/the Mineriads), oscillating between a normal left-wing legacy ("the noble ideals of socialism", as Ion Iliescu put it at the end of 1989) and its rejection and, at the same time, between authoritarianism and reform, PSD (former National Salvation Front/FSN, National Democratic Salvation Front/FDSN, Romanian Social Democracy Party/PDSR) creates for itself, although with difficulty and gradually (and through the alliance with PSDR) an identity contour.

The period that followed after 2000 brings certain clarifications, from the point of view of conformity (and the lack of exceptionality) of PSD programs compared to the socialEuropean democracy of which it is already an institutional part. The discussion over the ideological unification was, up until 2005, concerning the right-wing as well as the left-wing Romanian parties, but from that year, PSD remains the only left-wing Romanian party, with the Democratic Party (PD) moving to European Populists. However, to make things more 
Issue no. $23 / 2017$

complicated, the years after its 2004 electoral defeat the Social Liberal Union was set up, by allying with the National Liberal Party (PNL). At the same time, starting with 2008, the Romanian electorate became, according to the results of surveys, more receptive to the ideological dimension. Even after the dissolution of the USL, certain "deviationist" rightwing ingredients continued to exist in the political programs and policy proposals submitted/endorsed by PSD and in the speeches of its leaders.

Such a tension seems to exist at the level of political documents elaborated by the party for the 2016 November-December electoral moment, between general programs and the ensemble of proposed public policies (the electoral manifesto), the latter incorporating sets of measures traditionally seen as belonging to the right-wing economic politics. If these are proof of populism (and some would also add the term "irresponsible"), in trying to capacitate a right-wing electorate, of pragmatism or rather of a bold, creative and innovative political and economic approach remains to be proved by the future events.

A few months after winning the parliamentarian elections with an unexpected result (over $45 \%$ of votes for the Senate and the Chamber of Deputies), and despite the efforts of defining a leftist identity, the ideological monopoly of PSD ends up being challenged by a platform ${ }^{21}$ that is yet unknown and in the process of being organized, one that claims to be a part of the new European left.

\section{Bibliography}

- BALL, T./ DAGGER, R. (2000) Ideologii politice şi idealul democratic. Iași: Editura Polirom.

- BERNSTEIN, E. (1907/1899) Evolutionary Socialism. Available from: https://www.marxists.org/ reference/archive/bernstein/works/1899/evsoc/index.htm [Accessed 20.09.2017].

- BUDGE, I. (2006) Identifying Dimensions and Locating Parties: Methodological and Conceptual Problems, in KATZ R. S./ CROTTY W. M. (eds.) - Handbook of Party Politics. London and Thousand Oaks, CA: Sage, pp. 422-433.

\footnotetext{
${ }^{21}$ Demos platform (http://platforma-demos.ro/)
} 
- CARPINSCHI, A. (1998) Doctrina social-democrată, in MUNGIU-PIPPIDI, A. (ed.) Doctrine politice. Concepte universal și realități românești. Iași: Editura Polirom, pp. 175-194.

- DUVERGER, M. (1990/1951) Caucus and Branch, Cadre Parties and Mass Parties, in MAIR P. (ed.) The West European Party System. Oxford: Oxford University Press, 1990, pp. 37-45.

- GAllagheR, T./ LAVER, M./ MAIR, P. (2002) Representative Government in Modern Europe. New York: McGraw-Hill, pp. 202-232.

- HEGEL, G. W. F. (2000) Fenomenologia spiritului. București: Editura Univers Enciclopedic.

- JURCA, N. (1994) Istoria social-democrației din România. București: Editura Științifică

- KIRCHHEIMER, O. (1966) The Transformation of West European Party System, in LA PAlOMbarA, J./ WeINER, M. (eds.) Political Parties and Political Development. Princeton, NJ: Princeton University Press, pp. 177-200.

- $\quad$ KITSCHELT, H. P./ MANSFELDOVA, Z./ MARKOWSKI, R./ TOKA, G. (1999) PostCommunist Party Systems, Competition, Representation, and Inter-Party Cooperation. Cambridge University Press.

- KITSCHELT, H. P. (1995) The Formation of Party Cleavages in Post-Communist Democracies: Theoretical Propositions, Party Politics. vol. 1 no. 4 (Fall, 1995), pp. 447472.

- KITSCHELT H. P. (1992) The Formation of Party Systems in East Central Europe, Politics and Society. vol. 20 no. 1 (March, 1992), pp. 7-50.

- LENIN, V. I. (1916) Imperialismul, stadiul cel mai înalt al capitalismului, in LENIN, V. I (1970) Opere alese. București: Editura Politică, pp. 75-213. Available from: https://www.marxists.org/reference/archive/bernstein/works/1899/evsoc/index.htm, [Accessed 20.09.2017].

- LUPU, H. (2017) - PSD, în dreapta stângii europene (dosarul „Social-democrația azi”), Dilema Veche nr. 674, 19-25 January 2017, pp. IV-V. Available from: http://dilemaveche.ro/sectiune/ tema-saptamanii/articol/psd-in-dreapta-stingii-europene, [Accessed 20.09.2017].

- MARX, K., ENGELS Fr. (1956/1845) Ideologia germană. București: Editura de stat pentru literatură politică, pp.14-48. 
- MARX, K., ENGELS, Fr. (1962/1848) Manifestul Partidului Comunist. București: Editura Politică.

- NEUMANN, S. (1990/1956) The Party of Democratic Integration, in MAIR P. (ed.) The West European Party System. Oxford: Oxford University Press, 1990, pp. 46-49.

- PROCA, O. G. (2010) Social-democrația în România pre-comunistă: geneza mișcării politice socialiste și tema autenticității, in Analele Științifice ale Universității ,Al. I. Cuza” din Iași, Științe Politice. tom V/2010, pp. 1-39.

- SARTORI, G. (2012) Partide și sisteme de partide. Cluj-Napoca: Editura CA Publishing.

- SEILER, D. (1999) Partidele politice din Europa. Iași: Institutul European.

- STOICA, S. (2004) Dicționarul partidelor politice din România, 1989-2004. București: Editura Meronia.

- WARE, A. (1996) Political Parties and Party Systems. Oxford: Oxford University Press, pp. 17-49 (62).

PSD online resources [Accessed 01.09.2017-20.09.2017]:

Political programs:

- (www.psd.ro)

- http://www.psd.ro/despre/cine-suntem

- http://new.psd.ro/despre/in-ce-credem

- http://new.psd.ro/viziune/politica-psd

- $\quad$ http://new.psd.ro/viziune/psd-in-2016

- $\quad$ http://new.psd.ro/viziune/psd-isi-asuma-trecutul

- $\quad$ http://www.psd.ro/viziune/proiectele-psd

Electoral manifestos:

- http://www.psd.ro/media/stiri/programul-economic-al-partidului-social-democrat-click-pe-fotode-mai-sus-pentru-a-vizualiza-prezentarile

- $\quad$ http://psd.ro/assets/pdf/Programul\%20economic\%20al\%20PSD\%20-\%2022.09.2016.pdf

- $\quad$ http://www.psd.ro/assets/pdf/Programul_PSD_pentru_Sanatate_-_04.11_.2016_.pdf

- http://psd.ro/assets/pdf/Programul_PSD_pentru_Tineri_si_Sport_-_07.11_.2016_.pdf

- http://psd.ro/assets/pdf/Programul_PSD_pentru_agricultura_-_28.10_.2016_(1)_.pdf

- http://psd.ro/assets/pdf/Programul_economic_al_PSD_(partea_a_11-a)_-_09.10_.2016_.pdf 


\title{
THE EUROPEAN UNION - GETTING SPEEDS ON THE POLITICAL AGENDA, LOSING SPEED ON THE INTERNET
}

Cristian POPA,

PhD Student,

Faculty of European Studies,

Babeș-Bolyai University Cluj-Napoca

popa.cristian@ubbcluj.ro

\section{DOI:10.24193/OJMNE.2017.23.05}

\begin{abstract}
A quick incursion in the Virtual World to explore the recent [political] history and anticipate trends on certain topics, with the help of the Big Data tools. Just a glimpse to the gross figures revealed by the analytics behind the search engines and the corresponding databases can give us a remarkably accurate prospective upon the interest of the general population [with Internet access] over time on some topics, as "European Union", "European elections", etc. As expected, the virtual world is in sync with the real world and from here we can infer that the activity of people on the Internet can predict the near future trends and stimulate us to try to learn how this trends works and how to influence it. In addition, observing the search trends can offer a fresh prospective upon the real meaning and dimension of the key events.

The objective of this paper is to illustrate how one can easily use Google Trends platform to visualize the trends of a selected topic or search term, to further analyze this trend in context and infer some conclusions upon the variations, and use the data to try to make predictions for the future trends.
\end{abstract}

Keywords: new media, European Union, European elections, Google trends, forecasting, nowcasting.

Once the Internet reached its maturity together with the increasing speeds and larger access, the virtual space became more and more a key place on the "Public Sphere" at the Global level. Through a variety of communication means - from online newspapers to the blogs and social media - the "Internet media" managed to overtake, one by one, the pillars of the "establishment", taking globally a first place in the audience polls.

But unlike its "classical" rivals (print news, television, radio), the internet, more specifically the "online media", has some unique, specific features that make it more sociologically interesting than the "classic" means of communications. 
Issue no. $23 / 2017$

In contrast to those, the Internet is not only a medium for the dissemination of information, but a complete system in which information is received, interpreted, transformed and sent back. Briefly, online, the information produces information. And the effect is quasiinstant.

No wonder it did not take long until the Internet became increasingly attractive to communicators and marketers. In parallel, with the direct commercial use, this new media has drawn attention of the researchers in social sciences, many of whom re-focusing on the exploitation of the new resources, both by classical means and by (new) scientific methods and models dedicated to investigating the evolution of subjects in this environment.

"Big data"22 or "Machine learning"23 for example, are terms and technologies that although based on not very recent scientific methods - have only made accessible with this unprecedented development and maturing of the online environment, with exponential increase in computational speeds and data storage. For those involved in social research, it became quite clear that human interaction with this emerging world may be an important indicator of the general or particular state of some systems, but also an interesting and absolutely novel predictor. With the evolution and refinement of the accessory technical means (from infrastructure, to access points) and the increasing access to the Internet, the sensitivity of this predictor has increased steadily.

One of the already established sensitive indicators of the public's interest in certain topics is their interaction with the search engines. In principle, a "search engine" is a complex information system that actively monitors websites created by third parties, inventories, indexes and sorts them according to certain criteria - specific to each operator - the result being an interrogable database, accessible to the public. The number of searches on a particular keyword or group of words reflects in the most brutal and direct way the interest in a given moment of the audience for a subject characterized by those keywords. The sensitivity of the search analysis depends and can be affected by many factors (language, regionalization, confusion of terms, erroneous or approximate entries, etc.), but for very general topics that can be characterized by well-established keywords and for which there is a very large number of results to be assessed, gross search analysis may be sufficient at least to outline some assumptions, if not even to draw (some) conclusions.

\footnotetext{
22 "Big Data is high-volume, high-velocity and/or high-variety information assets that demand cost-effective, innovative forms of information processing that enable enhanced insight, decision making, and process automation". (Gartner.com, 2017)

23 "Advanced machine learning algorithms are composed of many technologies (such as deep learning, neural networks and naturallanguage processing), used in unsupervised and supervised learning, that operate guided by lessons from existing information." (Gartner.com, 2017)
} 
Issue no. $23 / 2017$

In 2006, the largest search engine operator by the date, Google Inc., with his google.com search engine, introduced a research tool accessible to any Google Account holder, called Google Trends ${ }^{24} \mathrm{TM}$. It allows searching one or more keywords and delivering statistics on how often they are used over time (starting from 2004), or in a given interval of given time. Google Trends ${ }^{\mathrm{TM}}$ can be used to track topic development in various fields and related literature has already been generated about the effectiveness or ineffectiveness of this tool.

A number of researchers in various domains have focused attention on this tool, in order to use it in a positive way, mainly by exploring or enhancing the methods to understand and predict data in domains like financial markets and biostatistics, especially by "nowcasting" - a term brought from meteorology - meaning observing the near past, the present and from here anticipating the near future.

Google itself launched a trend in using Trend in a search for predictions on certain topics. Predicting the Present with Google Trends (Varian, Hal, 2009; Varian, Hal, 2012) are two papers illustrating how to do this, with examples, which soon become common knowledge and first reference in such study. However, a real hit was attained by now notorious Google Trends sub-branches Google Flu Trends ${ }^{25}$ or Google Dengue Trends, large global projects developed and run by Google Inc. between 2008 and 2014, meant to estimate the influenza and dengue fever outbreaks in particular countries, based solely on Internet search. The assumption is that a search surge on such topic and related topics is a very strong predictor for an abnormal activity of the disease and an early warning, otherwise missing, since the visits to the doctors - and the subsequent data - occurs usually late, when the symptoms are more accentuated (Ginsberg et al., 2009; Carneiro, Mylonakis, 2009). Google disrupted publishing trend data in 2014, but the data is still available for research. Likewise, the authors of a study on Lyme disease spreading concluded that the Internet searches "may not only aid outbreak surveillance but also identify more subtle geographic spread in incidence of endemic diseases such as Lyme" (Seifter et. al., 2010). Other scholars and experts focused their attention in predictive power of the Internet search in economics related domains, like consumer behaviour (Carrière-Swallow, Labbé, 2013), tourism trend and tourist behaviour (Yang et. al, 2015; Bing, Yang, 2017) and, of course, financial markets (Preis et al., 2013), the authors starting from the idea that "Google Trends data did not only

\footnotetext{
${ }^{24}$ https://trends.google.com/trends/ [Accessed 09/2017]

${ }^{25}$ https://www.google.org/flutrends/about/ [Accessed 09/2017]
} 
Issue no. 23/2017

reflect the current state of the stock markets, but may have also been able to anticipate certain future trends."

More recently, some scholars revisited the topic and some skepticism arise: Is really internet search such powerful tool? In his paper "Nowcasting with Big Data: is Google useful in Presence of other Information?" (Li, 2016), Li has proven that forecasting on internet search is of lesser impact in economic fields like job claims and employment when real data prevails in quantity and quality. However “(...) for countries, whose data quality is poor or where there are very few forward-looking variables (surveys) and data publication is subject to severe delay, search data might provide extra information and its timely publication can be beneficial in forecasting or even cross-validating the real economic data" is a collateral conclusion drawn from the same study ( $\mathrm{Li}, 2016)$.

\section{European Union topic on the virtual world}

Inspired from this prospective, we will try to switch the topic to some social issues and politics and contemplate the life of the European Union on the Internet. While the Euroscepticism $^{26}$ is constantly eroding the EU agenda for years now, the recent "-exits" like Grexit $^{27}$ and Brexit ${ }^{28}$ has abruptly shaken the EU.

In the following paragraphs we will apply trend query to some European Union related topics within the available timeframe (2004 - present) using Google Search engine and other Google proprietary tools, as presented, and use the comparative approach to understand and explain some of those trends.

Some useful remarks about the procedure:

- Google's search algorithm is based on "relevancy," a concept that combines over 200 factors, the most important of which is "Page Rank," a measure of the importance of a page compared to another, based firstly on the number of "high prestige" valid references (links) to it (Google.com, 2017).

- Keywords have been chosen to eliminate ambiguities as much as possible. Thus, the pair of words "union" + "European" (in any form) sends first to the organization of the same name (EU), in any language. Unlike Google Search, Google Trends, in addition, makes this distinction actively and filters out irrelevant results.

\footnotetext{
${ }^{26}$ EU-scepticism, see https://en.wikipedia.org/wiki/Euroscepticism

${ }^{27}$ GReece-EXIT, see https://en.wikipedia.org/wiki/Greek_withdrawal_from_the_eurozone

${ }^{28}$ BRitish EXIT, see https://en.wikipedia.org/wiki/Brexit
} 
- Google Trends analyzes part of the searches on a net topic or specific keywords. Are actively eliminated from the analysis the inputs that could corrupt the result, such as "duplicate" searches (repeated searches made by the same user within a short period of time), special characters and mistakes, searches made by a small / homogeneous group of users etc., maintaining only very popular searches.

- Data is adjusted by Google Trends algorithm in a way to compensate the differences in volume, by proportionate them by time and location. ${ }^{29}$

- The results in this study are collected from global search database ("Worldwide"), restrictions by regions being possible. However, for the scope of this paper the worldwide setting is sufficient and the results are illustrative.

\section{Preliminaries}

A search on Google.com with the words European + Union generates over 280 million results ${ }^{30}$ (accessible pages) and the search for the acronym "EU" somewhere over 2.7 billion, of which perhaps a very large part is due to ambiguity. The result itself is not surprising, nor is the fact that the first pages of suggestions are almost exclusively directed to the official sites of European bodies, large encyclopaedias and portals of European media malls that have treated and treats the subject in the current news. Such a general search can only reveal the huge amount of information we are talking about, impressive only through its magnitude. As a matter of fact, a similar search for the words United + States + of + America generated almost instantly $846,000,000$ results, and for China 3,390,000,000 results (in this case the ambiguity pointing to zero), which can put the EU's memory on the Internet in a comparative light.

More interesting results, however, are provided by Google Trends, a tool that does not refer the number of pages that contain this term, but to the interest of those who used the search engine on this topic.

\footnotetext{
${ }^{29} \mathrm{https} / / /$ support.google.com/trends/answer/4365533?hl=en\&ref_topic=6248052 [Accessed 09/2017]

${ }^{30}$ Search time September 2017 - the search results may vary, usually with increasing numbers over time.
} 
Issue no. $23 / 2017$

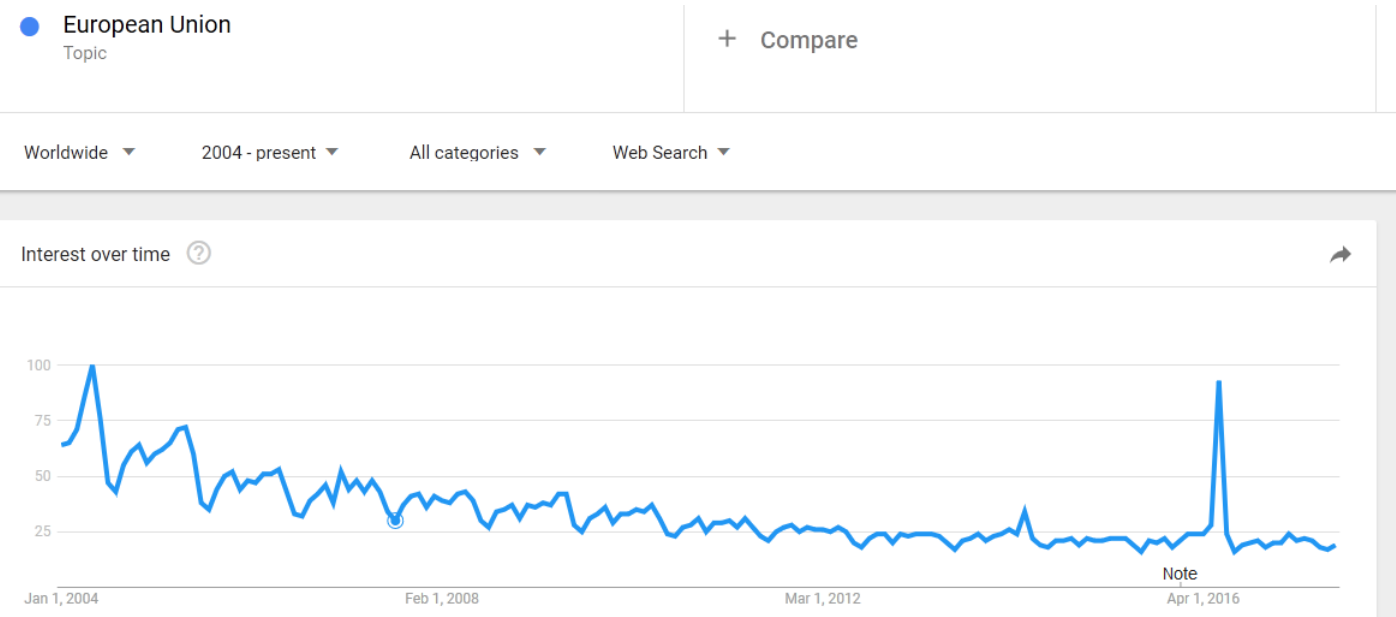

Graph 1. Google Trends - Topic "European Union" 2004 - present, Worldwide,

Data source: Google Trends 09/2017 (www.google.com/trends)

The graph above (Graph 1) gives us the popularity of the topic "EUROPEAN UNION" from 2004 to the present. In Google Trends logic, the graph points indicate the "popularity" of a search, that is, the total number of searches per topic or keyword at a given time, relative to the total number of searches on Google at that time. Thus, a downward trendline shows that the relative popularity of the search term has fallen. This does not necessarily mean that the total number of searches has dropped (less probable since from 2004 the global volume of searches has massively increased), but only that its relative popularity is decreasing.

The breakdown over time allows us to view the trend in detail and make certain assumptions about the upward or downward tendencies of the trend-line in the chart. If we focus on January 2004 - Dec 2007, the situation looks like this:

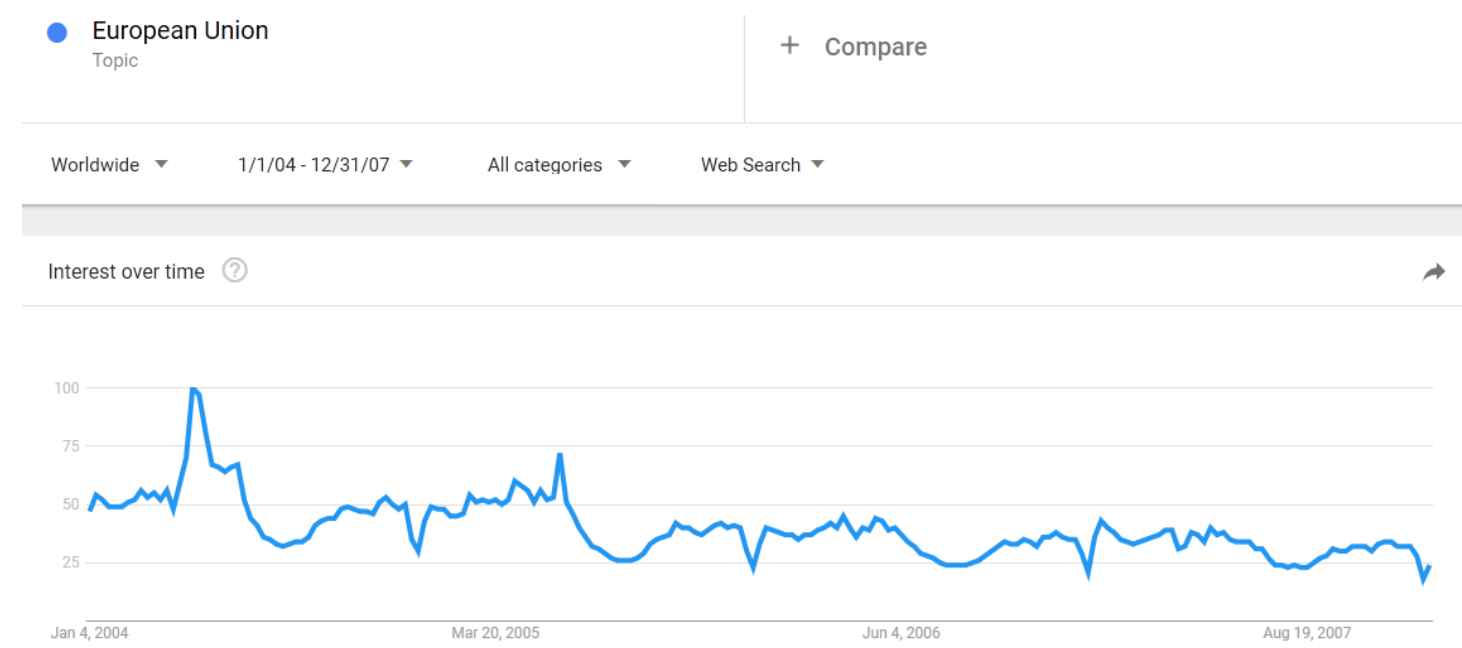

Graph 2. Google Trends - Topic "European Union" Jan 2004 - Dec 2007, Worldwide,

Data source: Google Trends 09/2017 (www.google.com/trends) 
Graph 2 illustrates that the peak of popularity is recorded in May 2004. On $1^{\text {st }}$ of May 2004, a historic event took place, the accession of 10 countries to the $\mathrm{EU}^{31}$, the largest enlargement of the Union in numerical terms as well as population and territory. After this turning-over event in the history of the EU, the search-trend drops again, perhaps to a "normal" of the era.

Looking deeper, is eye-catching that the peaks of Internet searches with the topic "EU" are usually in May. Thus, the next year, in May 2005, is the second "peak" of importance for the period 2004 - present (see Graph 3 for details), preceded by a small jump in October 2004. Looking retrospectively, we notice that on 29 October 2004 the 25 Member States sign, in Rome, Italy, "The Constitutional Treaty" - Treaty establishing a Constitution for Europe (Europa.eu, 2005) - a brave and unprecedented step in European construction. The ratification process started successfully the following spring in Spain and succumbed suddenly to France's rejection vote on May 29, 2005. (On July 10th, the Netherlands and Luxemburg symbolically, but unnecessarily, approve the first European Constitution, already dead.)

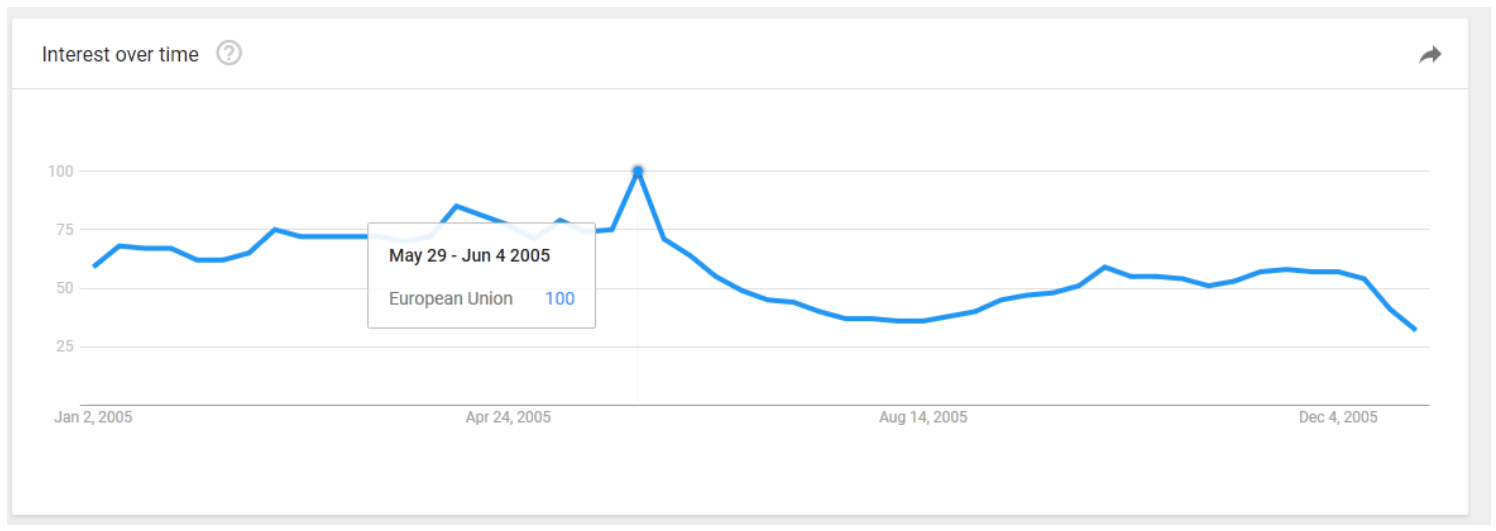

Graph 3. Google Trends - Topic “European Union” 2005, Worldwide,

Data source: Google Trends Sep 2017 (www.google.com/trends)

Simply by breaking down this graph of searches on the Internet we can witness the fate of the Constitutional Treaty and the idea of a Constitution for Europe from its launch to the bitter end.

Further, Google Trends provides us the means to explore certain interests over regions.

\footnotetext{
${ }^{31}$ Cyprus, Czech Republic, Estonia, Hungary, Latvia, Lithuania, Malta, Poland, Slovakia, Slovenia;
} 
Issue no. 23/2017

\begin{tabular}{|c|c|c|}
\hline & Country & $\begin{array}{l}\text { European } \\
\text { Union: (2005) }\end{array}$ \\
\hline 1 & Luxembourg & 100 \\
\hline 2 & Lithuania & 48 \\
\hline 3 & Latvia & 48 \\
\hline 4 & Malta & 42 \\
\hline 5 & Bulgaria & 37 \\
\hline 6 & Slovakia & 37 \\
\hline 7 & Czech & 36 \\
\hline 8 & Romania & 34 \\
\hline 9 & Austria & 34 \\
\hline 10 & Cyprus & 33 \\
\hline 11 & Poland & 32 \\
\hline 12 & Hungary & 32 \\
\hline 13 & Ireland & 31 \\
\hline 14 & Estonia & 29 \\
\hline 15 & Portugal & 27 \\
\hline 16 & Belgium & 27 \\
\hline 17 & Germany & 27 \\
\hline 18 & Greece & 25 \\
\hline 19 & Palestine & 24 \\
\hline 20 & Denmark & 23 \\
\hline 21 & Slovenia & 22 \\
\hline 22 & Serbia & 21 \\
\hline 23 & Sweden & 20 \\
\hline 24 & Turkey & 19 \\
\hline 25 & Ukraine & 19 \\
\hline 26 & France & 18 \\
\hline 27 & Finland & 18 \\
\hline 28 & Croatia & 17 \\
\hline 29 & Netherlands & 15 \\
\hline 30 & Norway & 15 \\
\hline 31 & Spain & 14 \\
\hline 32 & Switzerland & 14 \\
\hline 33 & United Kingdom & 12 \\
\hline 34 & Italy & 12 \\
\hline 35 & Ecuador & 11 \\
\hline
\end{tabular}

Table 1. Google Trends - Topic "European Union” 2005, Interest by region, Worldwide,

Data source: Google Trends 09/2017(www.google.com/trends) 
Table 1 shows the interest over "European Union" Topic in year 2005 by region $(\text { country level) })^{32}$. We can see an increase in relative queries, in general, in the former "Eastern-Block" countries and in the new members, and a less interest in Western countries and "old" members. The trending search term over the year 2005 related to the European Union was "Constitution" (see Table 2) which can enable us to say that the European Constitution was really a "hot" topic of the year, observation further sustained by the "rising" metric of the same report ${ }^{33}$ (Table 3), where terms like "Constitution", "Referendum" or "Voting" related to the EU general topic are trending.

\begin{tabular}{|l|l|l|}
\hline \multicolumn{2}{|c|}{ TOP - Top } & \\
\hline $\mathbf{1}$ & Europe & 100 \\
\hline $\mathbf{2}$ & Constitution & 20 \\
\hline $\mathbf{3}$ & Member state of the European Union & 15 \\
\hline $\mathbf{4}$ & European Commission & 15 \\
\hline $\mathbf{5}$ & Country & 10 \\
\hline $\mathbf{6}$ & Directive & 10 \\
\hline $\mathbf{7}$ & Turkey & 5 \\
\hline $\mathbf{8}$ & Poland & 5 \\
\hline $\mathbf{9}$ & Treaty & 5 \\
\hline $\mathbf{1 0}$ & Import & 5 \\
\hline $\mathbf{1 1}$ & European Economic Community & 5 \\
\hline $\mathbf{1 2}$ & Euro & 5 \\
\hline
\end{tabular}

Table 2. Google Trends - Topic "European Union" 2005, TOP Related topics, Worldwide,

Data source: Google Trends 09/2017 (www.google.com/trends)

\footnotetext{
${ }^{32}$ Values are calculated on a scale from 0 to 100 , where 100 is the location with the most popularity as a fraction of total searches in that location, a value of 50 indicates a location which is half as popular, and a value of 0 indicates a location where the term was less than $1 \%$ as popular as the peak. Note: A higher value means a higher proportion of all queries, not a higher absolute query count. So a tiny country where $80 \%$ of the queries are for "bananas" will get twice the score of a giant country where only $40 \%$ of the queries are for "bananas". (Google Trends Help, 2017)

${ }^{33}$ Related topics: Users searching for your term also searched for these topics. You can view by the following metrics: $*$ Top - The most popular topics. Scoring is on a relative scale where a value of 100 is the most commonly searched topic, a value of 50 is a topic searched half as often, and a value of 0 is a topic searched for less than $1 \%$ as often as the most popular topic. * Rising - Related topics with the biggest increase in search frequency since the last time period. Results marked "Breakout" had a tremendous increase, probably because these topics are new and had few (if any) prior searches. (Google Trends Help, 2017)
} 
Issue no. $23 / 2017$

\begin{tabular}{|c|c|c|}
\hline Related topics & Rising & $\nabla \Rightarrow$ \\
\hline 1 Referendum - Topic & & $+200 \%$ \\
\hline 2 Constitution-Topic & & $+200 \%$ \\
\hline 3 Domain name - Topic & & $+100 \%$ \\
\hline 4 Voting-Topic & & $+70 \%$ \\
\hline 5 Negotiation - Topic & & $+60 \%$ \\
\hline
\end{tabular}

Table 3. Google Trends - Topic “European Union” 2005, RISING related topics, Worldwide,

Data source: Google Trends 09/2017 (www.google.com/trends)

In 2007, on May 1st, two more countries joined the European Union - Romania and Bulgaria - the trend line registering a new jump, but not as spectacular as the previous one. At the same time, a new EU Council is taking place in Brussels.

The 2009 and 2014 elections are the latest "twists and turns" of interest in the subject, notably the performance of the 2014 elections, with a peak for the 2010-2015 period, a period that is lingering from this perspective (Graph 1). However, a major "spike" over this sea of calm emerges in 2016 (see Graph 1). Without any exploration, one can say that this would be a (very) notable event in the history of the European Union. Zooming-in we can put the finger on the tip of the spear (Graph 4):

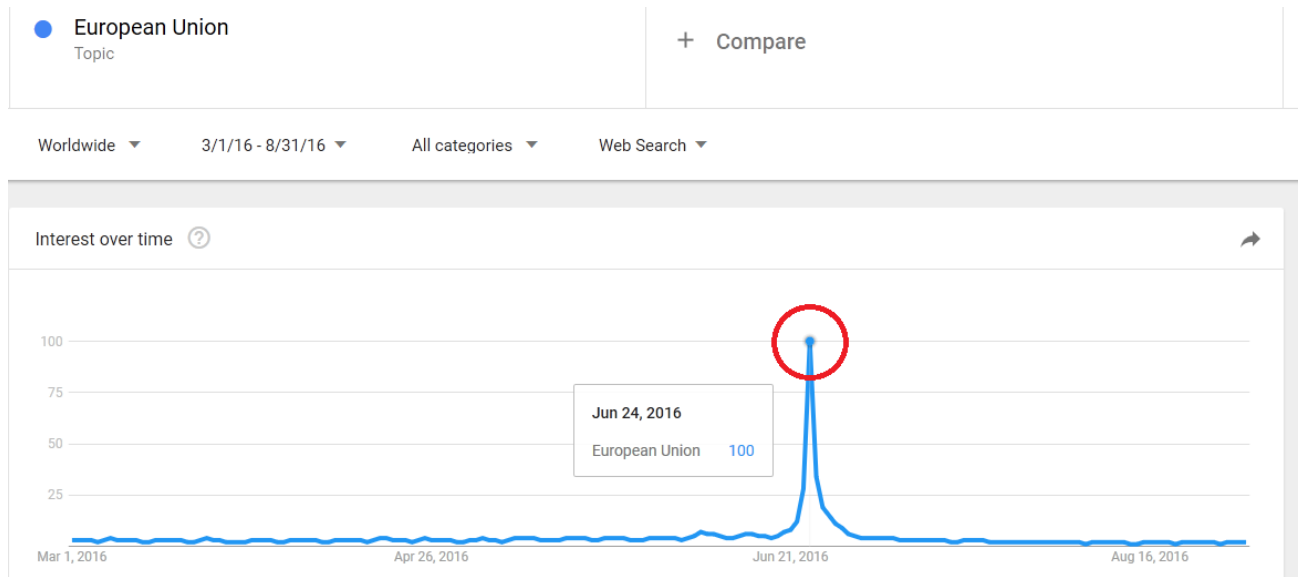

Graph 4. Google Trends - Topic “European Union” 2016 (May-Aug), Worldwide,

Data source: Google Trends 09/2017 (www.google.com/trends) 
Issue no. $23 / 2017$

What happened with the EU on June $24^{\text {th }}, 2016$ ? A brief Google search provides the answer in milliseconds (Picture 1):

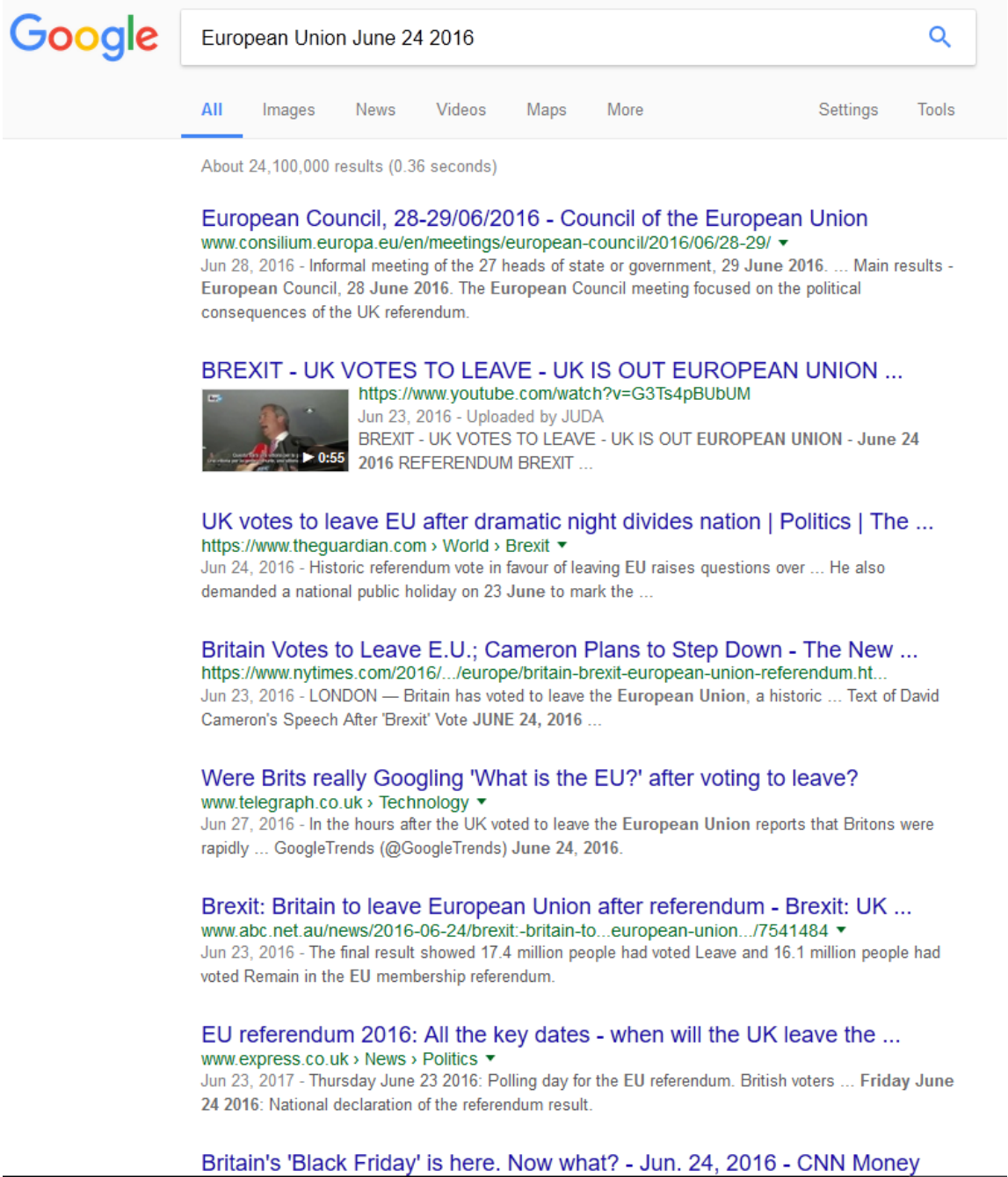

Picture 1. Google Search European + Union + June + 24 + 2016 [09/2017]

The referendum in UK sends a key member of the European Union outside the organization in an unprecedented event in its history, the "BREXIT" leaving the whole world stunned. It's not surprising that millions of searches over the Internet focused on the subject on that day.

However, what it is further remarkable and of interest is how a topic evolves on the people agenda, seen from the prospective of the Internet search. Graph 5 focuses on the days 
before and after the event, following the same search terms: European + Union. (As a matter of fact, searching on Brexit and United + Kingdom returns exactly the same "interest" pattern for the given period).

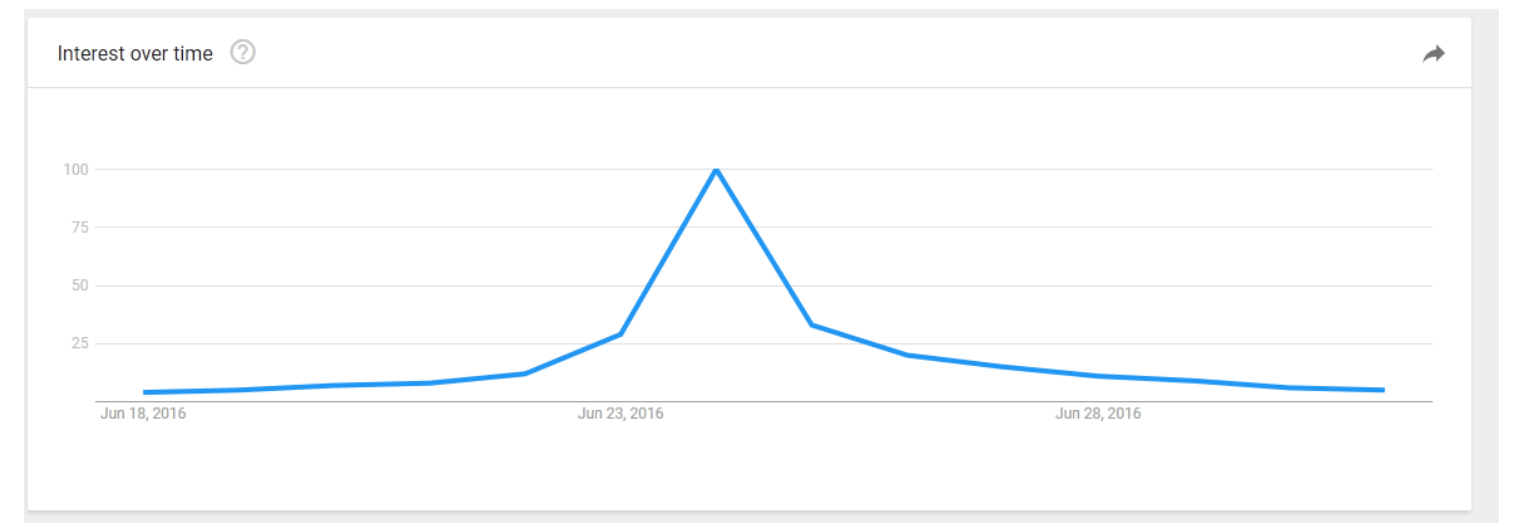

Graph 5. Google Trends - Topic "European Union” 2016 (Jun 18 - Jun 30), Worldwide, Data source: Google Trends 09/2017 (www.google.com/trends)

In the days before the British referendum people start to actively search the internet, the trending sub-topics being illustrative (Table 4):

\begin{tabular}{|l|l|}
\hline RISING & \\
\hline Nigel Farage & Breakout \\
\hline Voting & $1750 \%$ \\
\hline Member state of the European Union & $1150 \%$ \\
\hline David Cameron & $800 \%$ \\
\hline European Union & $700 \%$ \\
\hline United Kingdom European Union membership referendum, & $650 \%$ \\
\hline 2016 & $600 \%$ \\
\hline Boris Johnson & $550 \%$ \\
\hline Referendum & $350 \%$ \\
\hline Independence & $300 \%$ \\
\hline Gibraltar & $300 \%$ \\
\hline Gross domestic product & $300 \%$ \\
\hline Europe & $250 \%$ \\
\hline UK Independence Party & $250 \%$ \\
\hline Prime minister & $200 \%$ \\
\hline Stock market & \\
\hline
\end{tabular}


Issue no. $23 / 2017$

\begin{tabular}{|l|l|}
\hline Iceland & $180 \%$ \\
\hline Countries of the United Kingdom & $170 \%$ \\
\hline Parliament & $140 \%$ \\
\hline Scotland & $120 \%$ \\
\hline Great Britain & $100 \%$ \\
\hline
\end{tabular}

Table 4. Google Trends - Topic "European Union" 2016 Jun, RISING - Related topics, Worldwide,

Data source: Google Trends 09/2017 (www.google.com/trends)

Almost any of the top 20 search keywords recorded are directly related to the subject of the British Referendum. But if the interest rapidly builds-up in the eve of the event, it vanishes with the same speed right after it. In less than one week, the topic "European Union" returns to its "normal" values, as recorded at the beginning of the same month (Graph 6)

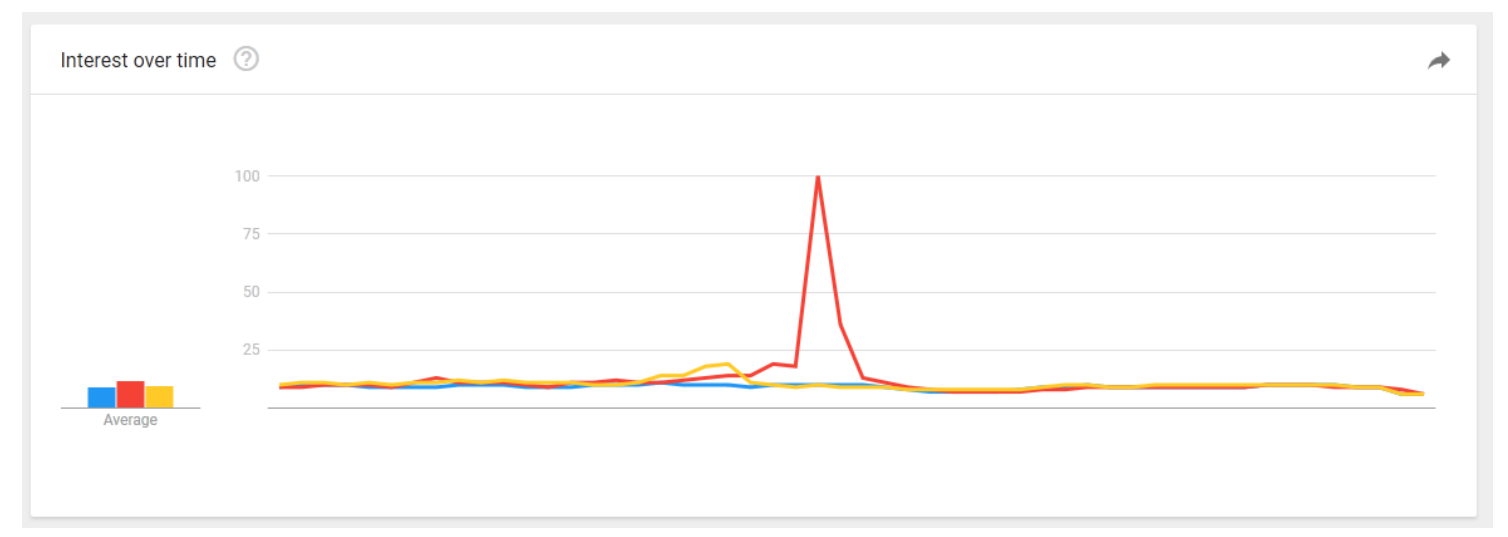

Graph 6. Google Trends - Topic "European Union" 2014, 2015, 2016, Worldwide,

Data source: Google Trends 09/2017 (www.google.com/trends)

Aside the extraordinary events present as extraordinary inflexion points in this timeline, the all-time evolution of the trend of the topic we investigate follows a non-linear pattern, with drops during the vacations and holidays, and rises once the people return to activities.

But there is more: we can notice increases in the trend line in some particular years (2004, 2009 and 2014) and some particular periods of those years overlapping - somewhere in May (Graph 7) 


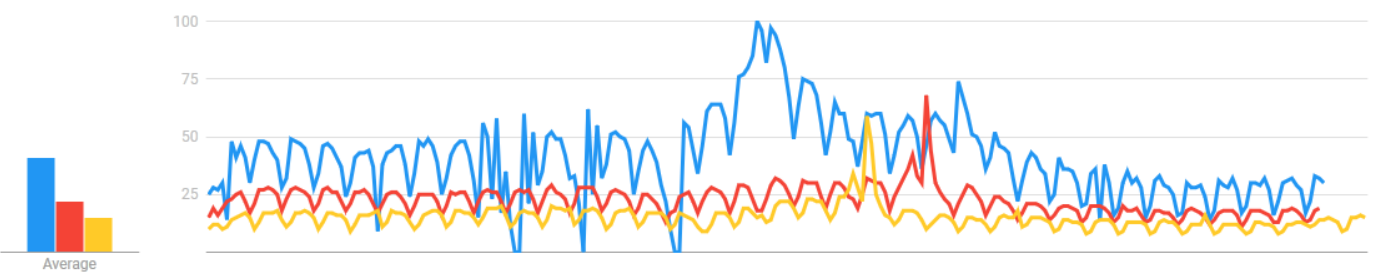

Graph 7. Google Trends - Topic “European Union” 2004, 2009, 2014, Worldwide,

Data source: Google Trends 092017 (www.google.com/trends)

Legend: Yellow: 2014, Red: 2009, Blue: 2004

Filtering-out the confounder(s) for the 2004 outstanding trend - i.e. the already mentioned accession to the club of the ten countries - the single major event of the period, being 1) related to the topic and 2) recurrent with a five years periodicity is the election for the European Parliament. We can verify this more accurately by switching the analysis to the related search terms / topic: As we see, the general trend of the interest for the topic "European Parliament" over the years is closely related to electoral periods (Graph 8).

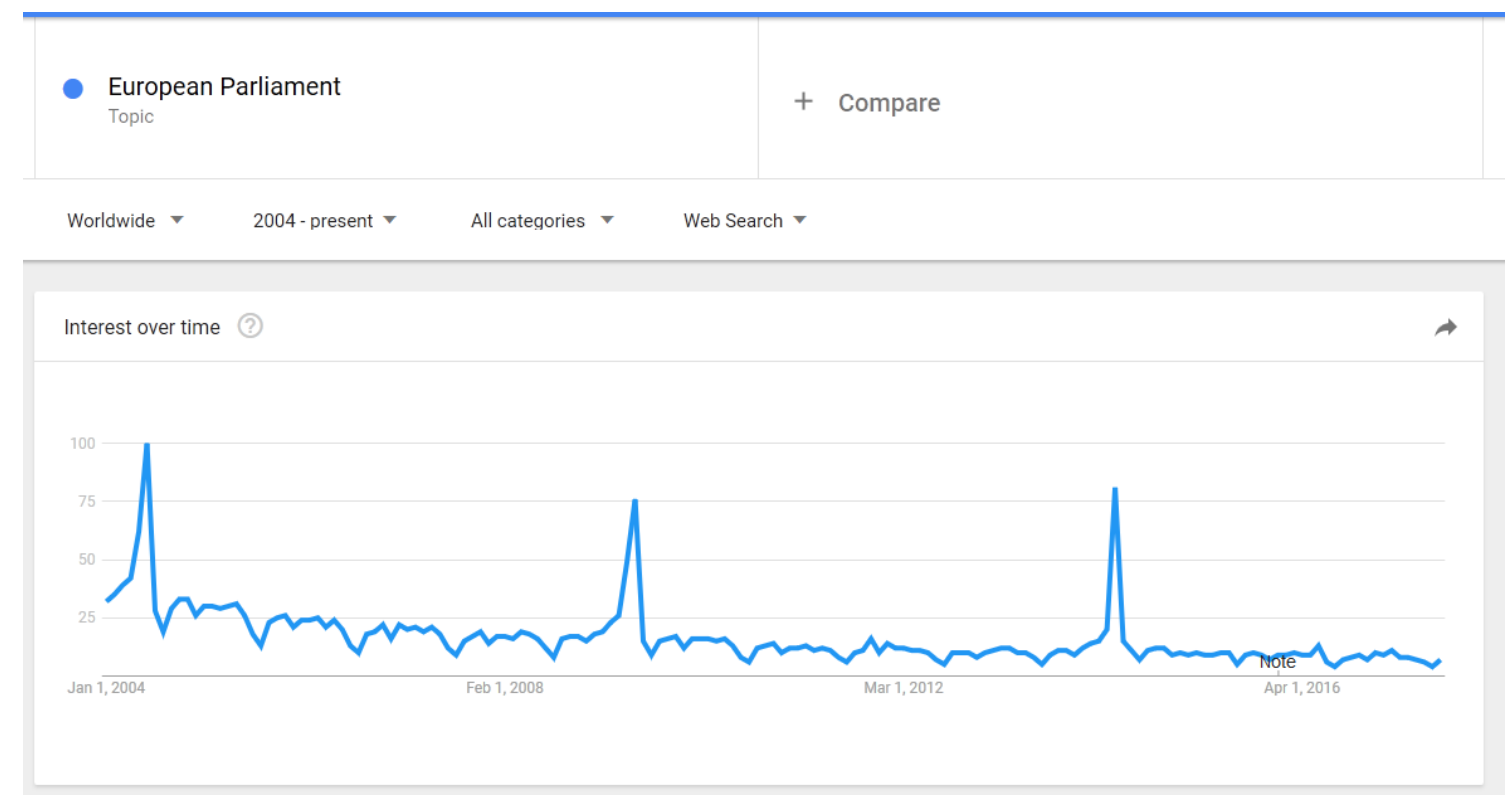

Graph. 8. Google Trends - Topic "European Parliament" 2004 - present, Worldwide,

Data source: Google Trends 09/2017 (www.google.com/trends) 


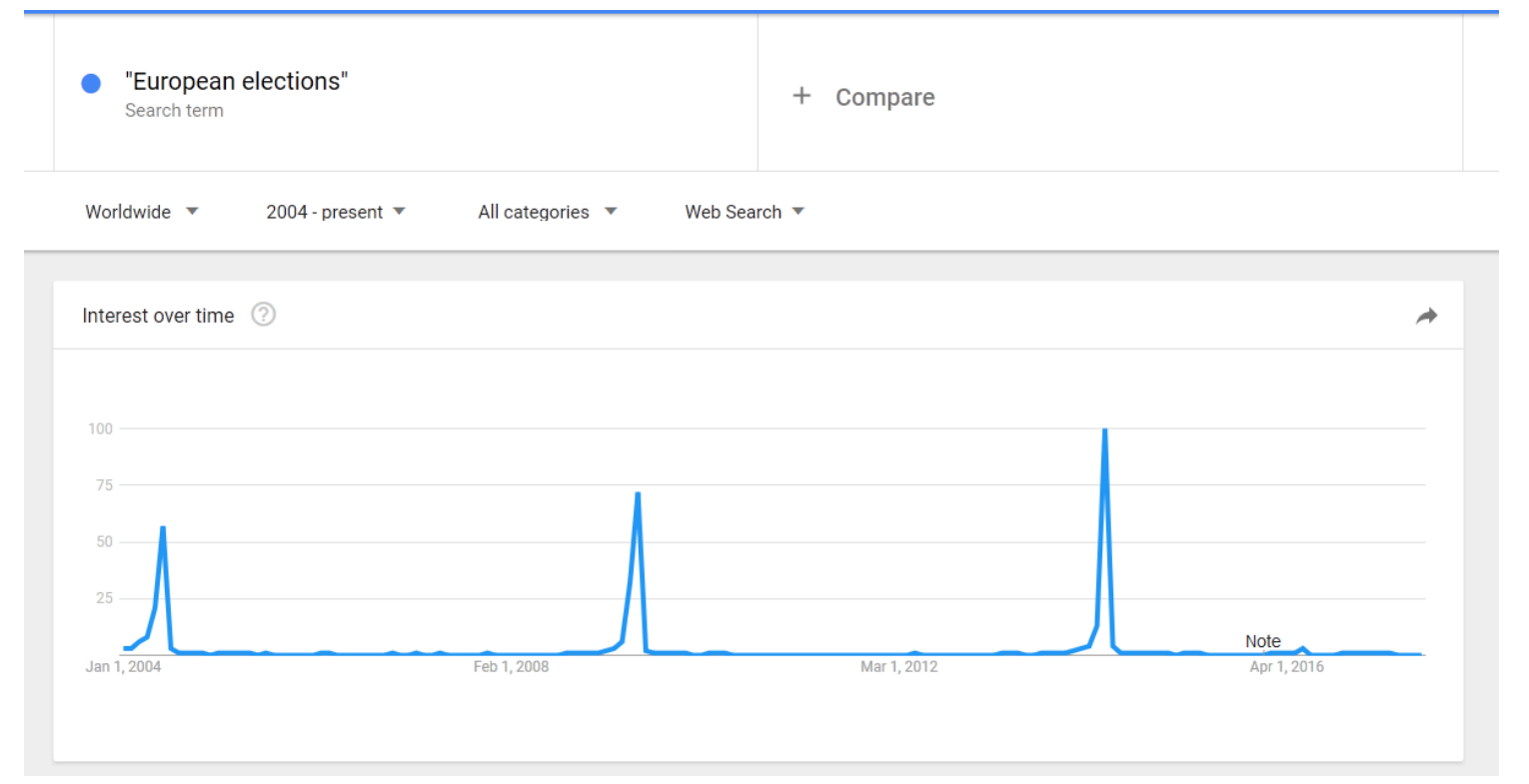

Graph. 9. Google Trends - “European elections" search term, 2004 - present, Worldwide,

Data source: Google Trends 09/2017 (www.google.com/trends)

Graphs 8 and 9 depicts with high precision the European election periods in the 2004 -2017 timeframe. $^{34}$

In Graph. 8 we can notice the general decrease in search (relative to the total searches) over this topic, "European Parliament", which is not surprising that a sub-topic follows the trend of the main topic. Let's compare this topic with a related one: "European Parliament" vs. "European elections" (restricted search term) ${ }^{35}$.

While the interest for the general topic "European Parliament" follows the general and already observed decreasing trend of the EU topic, the search term "European elections" (Graph. 9) appears to be more present from 2004 to 2014. Even if the analysis was restricted to the exact phrase, the result may be biased, mainly by disambiguation. However, this observation needs further attention, beyond the scope of this presentation.

Superimposing the above figures with the turnover in European elections over time, we can notice a match (see Graph. 10).

\footnotetext{
${ }^{34}$ Elections for the European Parliament - a.k.a. "the European elections" - are held each 5 years in May. Each member state is free to choose the election dates in a given interval in that month.

${ }^{35}$ In Google search, quotes restricts search to the exact phrase
} 


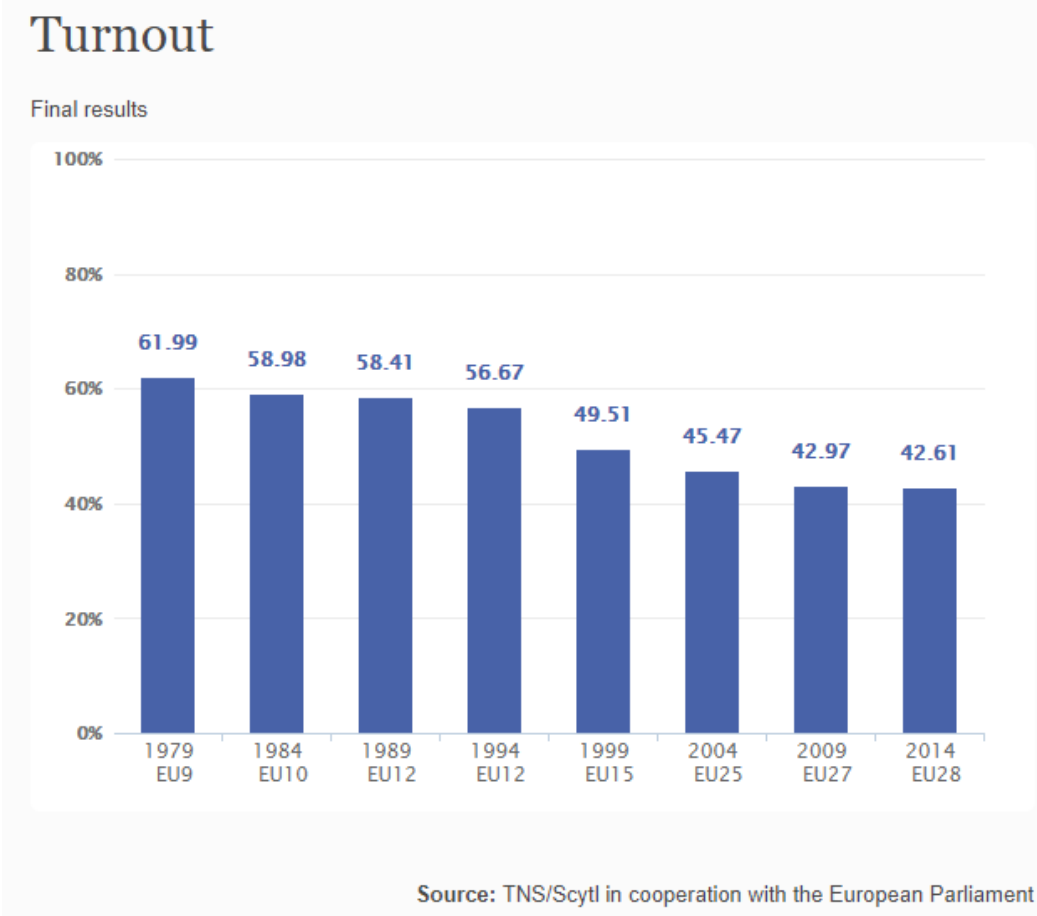

Graph. 10. Europarl.eu - Elections Turnout 1979 - 2014

Data source: TNS/Scytl in cooperation with the European Parliament (http://www.europarl.europa.eu/elections2014results/en/turnout.html)

The descending trend in search terms or topic is consistent with the voter turnout as registered in the past three rounds of EP elections. The right tail of the trend-line in Graph. 8 indicates a less pronounced decrease which is, again, in line with the turnout figures in the last elections $(2009,2014)$. This enables us to consider the internet search of general population as a weapon of choice, in the future, in forecasting electoral behavior of the EU citizens facing the EP elections. Considering a larger and deeper access to the internal databases for feature refining and selection, and with the aid of the emerging technologies, i.e. machine learning, a predictive model for the future of the EP and EU based on Internet queries looks more than promising.

Stepping a bit further, we can briefly analyze some other topics or keywords, the results being particularly interesting and inviting for possible more detailed studies.

As an example, the search popularity of the "European + integration" keywords follows a similar trend as the EU topic. (Graph. 11) 
- european integration $\quad+$ Compare

Worldwide 2004 - present $\quad$ All categories $\quad$ Web Search

Interest over time (2)

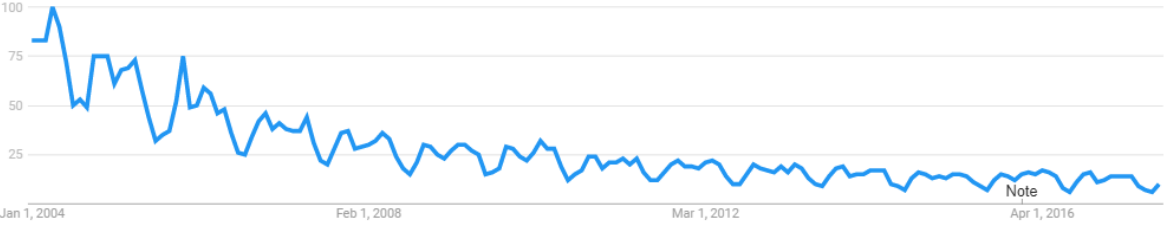

Graph. 11. Google Trends - "European integration" search term, 2004 - present, Worldwide,

Data source: Google Trends 09/2017 (www.google.com/trends)

The tip from which this chart starts is (also) the spring of 2004. But Google Trends provides a suplimantary time-line analysis feature, through media coverage (News - Graph. 12). From this prospective - of how the term/topic was reflected in the news-related-searches - a different point of flexion is in highlight, somewhere in October 2004. More precisely around the end of the month. In that particularr month, on October 29, "The heads of state and government and the EU Foreign ministers sign the Treaty establishing a Constitution for Europe" (Europa.eu, 2017). That event was a trigger for people's interest in the European politics. 

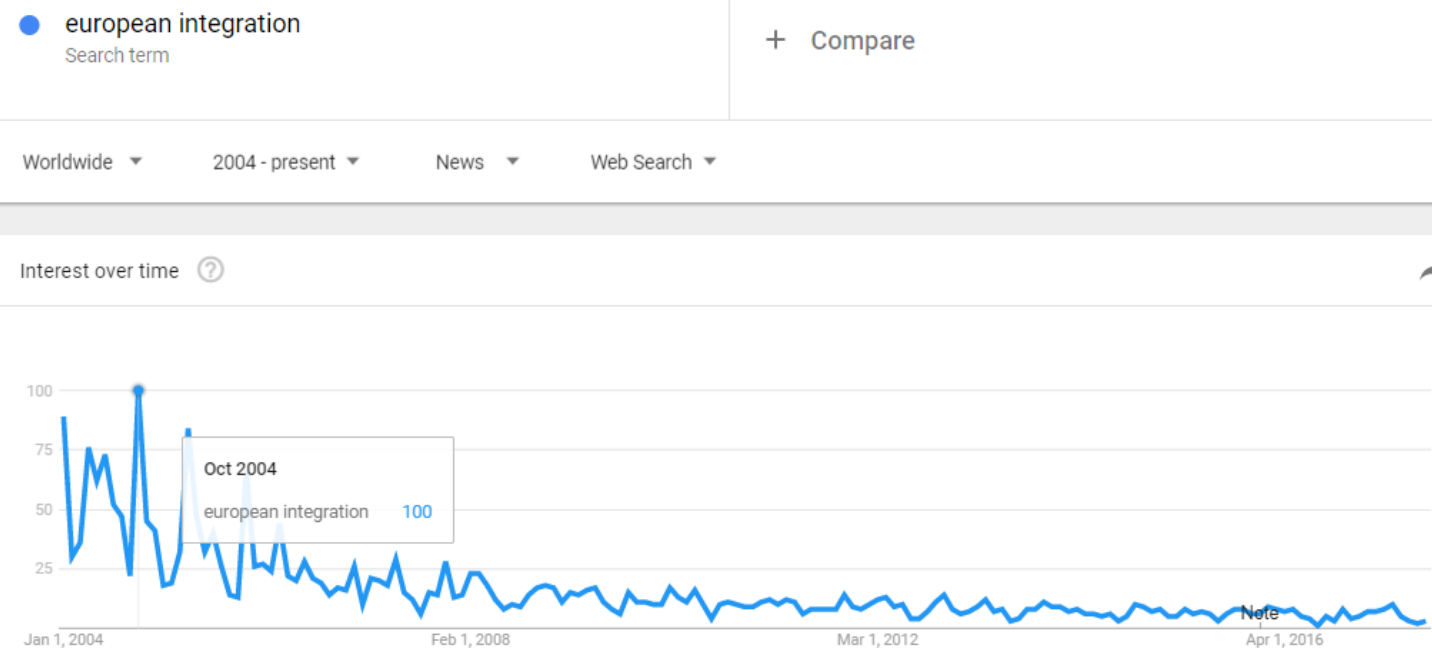

Graph. 12. Google Trends - "European integration" search term in the News, 2004 - present, Worldwide, Data source: Google Trends 09/2017 (www.google.com/trends)

GoogleTrends, unfortunately, does not have enough information to solve the ambiguity of searching under the terms "multi-speed Europe" or "two-speed Europe". It would have been interesting to see a trend of this topic revived by European politicians lately.

But the instrument gives us an unexpected picture of another "Euro-subject", which is more of a romantic outlook on the Union and which, in those days, seems completely out of the debate: the "United States of Europe" (Graph. 13, Graph. 14): 


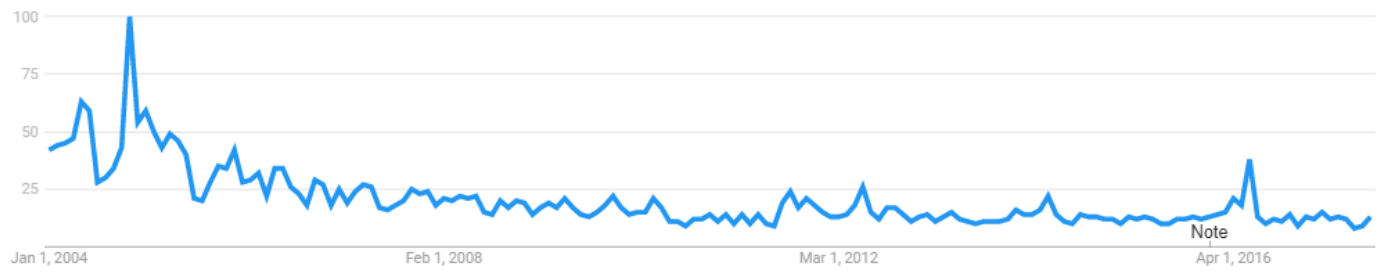

Graph. 13. Google Trends - "United States of Europe" Topic, all categories, 2004 - present, Worldwide, Data source: Google Trends 09/2017 (www.google.com/trends)
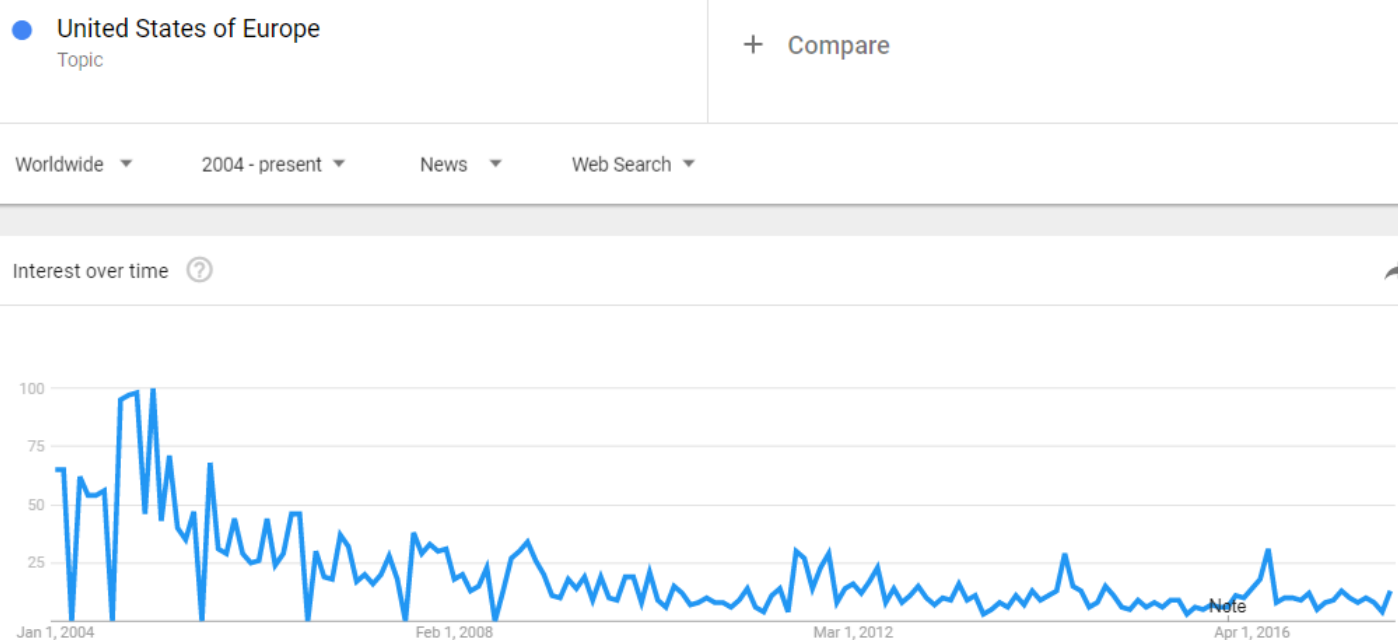

Graph. 14. Google Trends - "United States of Europe” Topic, in News, 2004 - present, Worldwide, Data source: Google Trends 09/2017 (www.google.com/trends)

Even if this topic looks obsolete or out fashioned to those following the EU politics, in an optimistic note for the supporters of a stronger EU, if a restrictive Internet search (exactly these words) still gives more than 30 million results - many of which of recent date -, it could suggest that this topic has not yet exhausted its fuel.

More, while Poland's, Czech Republic's and Hungary's democratic elected leaderships placed those countries' foreign politics in the last years on what is categorized as 
an Eurosceptic orbit, some of the highest hit rates on the topic on Google Trends News comes in the past five years from Hungary, Czech Republic and Poland (Graph. 15). It's interesting to know what citizens of this three countries are exactly looking for and expecting when querying the Internet about or how. While we can only speculate on this, the quantitative data only let someone to infer that is a certain elevated interest for the subject of the United States of Europe in that part of the EU.
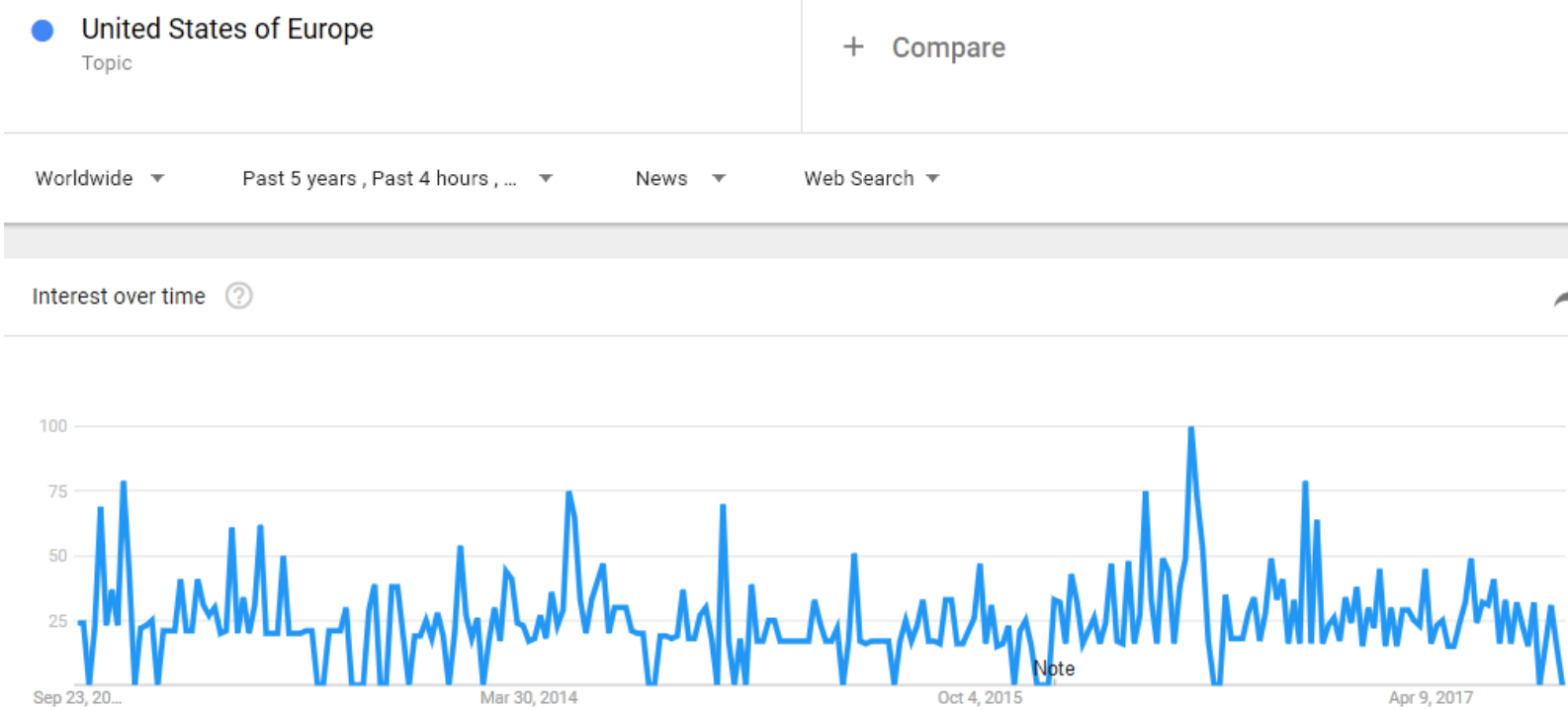

Interest by region (?)

\begin{tabular}{lllll}
\hline & Hungary & Region & \\
\hline 2 & Czechia & & \\
\hline 3 & Austria & & \\
\hline 4 & Poland & & \\
\hline 5 & Belgium & 79 & \\
\hline
\end{tabular}

Graph. 15. Google Trends - "United States of Europe" Topic, in News, 2012- - present, Trend and interest by Region, Worldwide,

Data source: Google Trends 09/2017 (www.google.com/trends) 
What people are getting by querying the Internet on this topic? A quick search on Google returns plenty of entries - both on general topics and the News -, from those explaining what "The US of Europe" is about as a theoretical concept, to Junker's 36 "plot" for a United Europe - subject covered, almost entirely, by the post-Brexit UK media. (Picture 2)

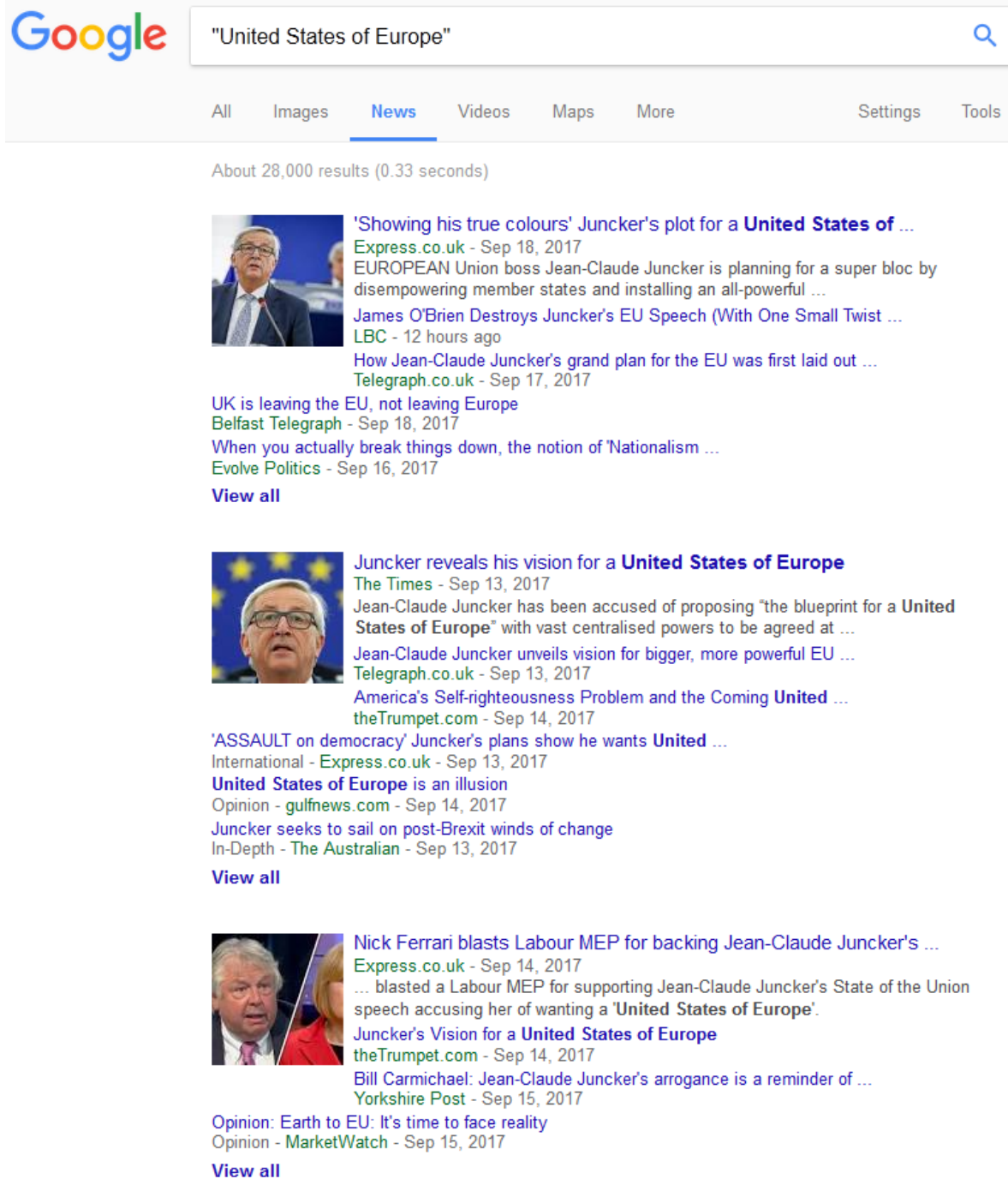

Juncker reveals his vision for a United States of Europe The Times - Sep 13, 2017

Jean-Claude Juncker has been accused of proposing "the blueprint for a United

States of Europe" with vast centralised powers to be agreed at

Jean-Claude Juncker unveils vision for bigger, more powerful EU

Telegraph.co.uk - Sep 13, 2017

America's Self-righteousness Problem and the Coming United theTrumpet.com - Sep 14, 2017

'ASSAULT on democracy' Juncker's plans show he wants United

ASSAULT on democracy Juncker's plans show
International - Express.co.uk - Sep 13, 2017

United States of Europe is an illusion

Opinion - gulfnews.com - Sep 14, 2017

Juncker seeks to sail on post-Brexit winds of change

In-Depth - The Australian - Sep 13, 2017

View all

Nick Ferrari blasts Labour MEP for backing Jean-Claude Juncker's Express.co.uk - Sep 14, 2017

blasted a Labour MEP for supporting Jean-Claude Juncker's State of the Union speech accusing her of wanting a 'United States of Europe'.

Juncker's Vision for a United States of Europe

theTrumpet.com - Sep 14, 2017

Bill Carmichael: Jean-Claude Juncker's arrogance is a reminder of

Opinion: Earth to EU: It's time to face reality

Opinion - MarketWatch - Sep 15, 2017

View all

Picture 2. Google Search “United States of Europe”, News section [Sep 2017]

\footnotetext{
${ }^{36}$ Jean-Claude Juncker
} 


\section{Conclusions. A glimpse in the future}

"Out of sight, out of mind", is a popular saying, meaning that what is less present, will be soon forgotten. Having that in mind, is a topic of less and less interest - in internet search ranking logic - condemned to disappear from the public agenda? In other words, is the declining interest in Internet searches over a topic a predictor for the expiration of the object of this topic? Apparently yes. Looking at the figures below (Graph. 16) we can contemplate the fate of once a popular and beloved support for music and films (the DVD), the short life of one of its challengers (iPod) and the rise of the new realm of personal media, the iPhone.

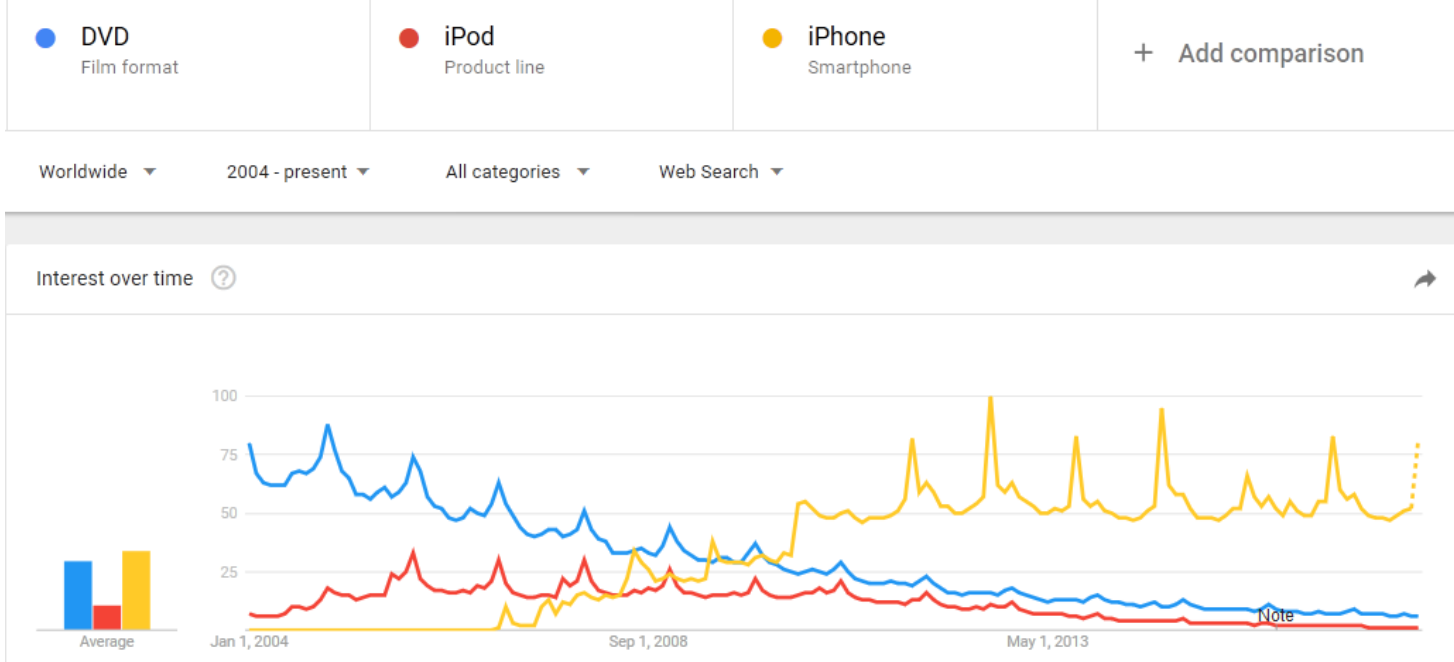

Graph. 16. Google Trends-DVD Vs. iPod vs. iPhone, Web search 2004 - present, Worldwide,

Data source: Google Trends 09/2017 (www.google.com/trends)

Can we generalize this observation?

Back to the base one (Graph. 1), we can notice a downwards trend and naïvely expect that the trend line will keep going down, but is this a valid prediction, or is just "predicting the present"? (Varian, Choi 2009). What Varian and Choi outline in their paper is how playing around with Google Trends one more likely can verify the present, instead of making an intuition on the future: "We are not claiming that Google Trends data help predict the future. Rather we are claiming that Google Trends may help in predicting the present. For example, the volume of queries on a particular brand of automobile during the second week in June may be helpful in predicting the June sales report for that brand, when it is released 
in July." However, as a footnote, the authors let the door open: "It may also be true that June queries help to predict July sales, but we leave that question for future research."

But can one really predict on this data? Basically what Google Trends provides us is a time series database we can see as a graph, but also download and play with. Statistics are offering all the tools necessary to handle such database, interrogate and make predictions on it. Applying time series analysis ${ }^{37}$ on the database Google Trends produced for the Topic "European Union" on searches from 2004 to date, we tried to forecast the near future trend on this topic. For this demonstrative purpose we used ARIMA $^{38}$ and dynamic forecasting after $\mathrm{VAR}^{39}$ in STATA $^{40}$ to predict the topic's trend in the next months after the date of data collection (Sep 2017). Both methods gave us the idea that for the next period (36 months) the World-wide search trend for the topic "European Union" on Google engine will keep dropping. (Graphs. 17, 18)

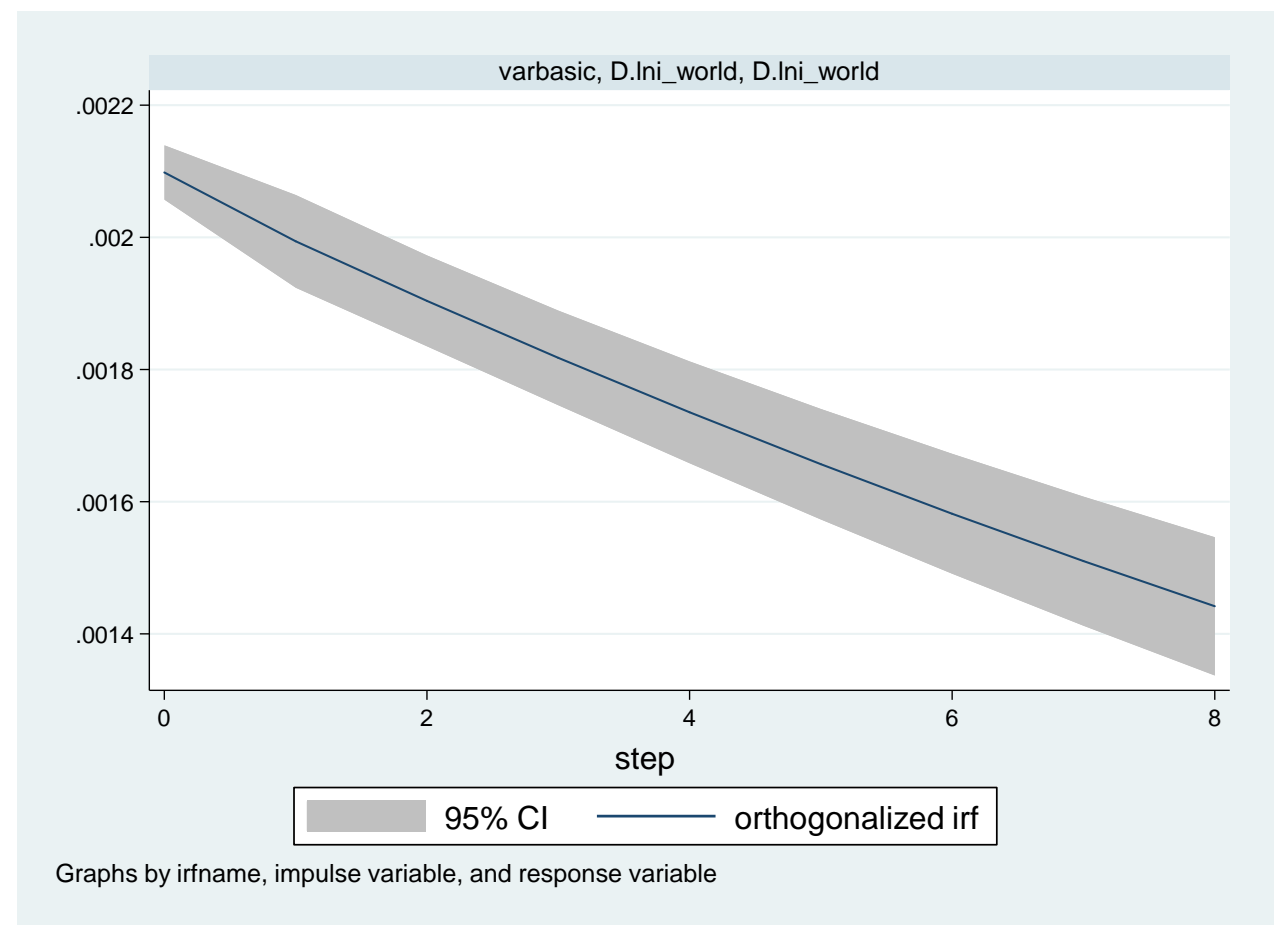

Graph 17. VAR trend for "European Union" topic trend data, TS Lag 3 periods (36 months),

Data source: Google Trends 09/2017 (www.google.com/trends), Analysis Stata15 / Vector autoregression

\footnotetext{
${ }^{37}$ https://en.wikipedia.org/wiki/Time_series

${ }^{38} \mathrm{https}: / /$ en.wikipedia.org/wiki/Autoregressive_integrated_moving_average

${ }^{39} \mathrm{https} / / /$ en.wikipedia.org/wiki/Vector_autoregression

${ }^{40}$ StataCorp. 2017. Stata Statistical Software: Release 15. College Station, TX: StataCorp LLC
} 


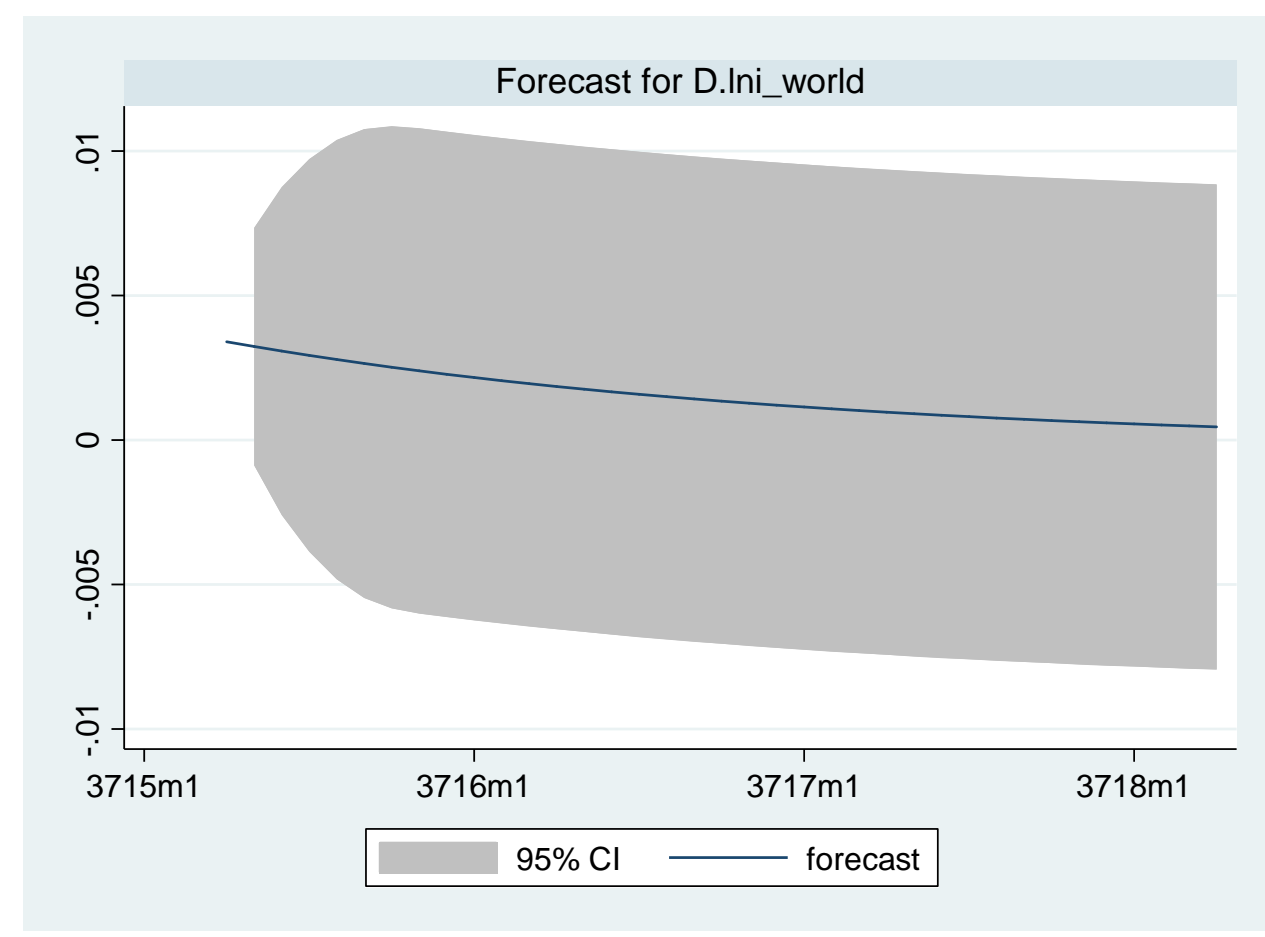

Graph 18. Dynamic forecast trend for “European Union” topic trend data, TS Lag 3 periods (36 months), Data source: Google Trends 09/2017 (www.google.com/trends), Analysis Stata15 /fcast

Autoregressive models are generally performing fine in extrapolating/predicting trends based on raw data. However, the Internet search specificity makes things a little harder. Sophisticated statistics above only tells us what was already in plain view and is already known for decades: the interest over that particular topic is far from rising.

But looking at details, what we can really learn by contemplating this figures is that a game changer - even if not a happy moment for the EU, like the Brexit - can rapidly and intensely re-focus the public opinion's attention back on the topic. The same analysis proves that recurrent moments in the life of the Union - like the European Elections, the $9^{\text {th }}$ of May etc. - constantly triggers the public attention. And this is worthy information, serving in understanding of how a topic can be kept alive and revived.

Analysis of the Internet searches is a relatively new player in the field of social research, gaining more and more attention. Vast resources are allocated to understand and make a potential profit from the new world where, more and more, the real world is moving 
rapidly. But even a brief and shallow exploration of this vast and continuously expanding resource unveils the huge analytical potential behind it. The more people get access to the Internet and interact with it, the more one observer can find about those people and their actions in the real world.

As seen in this paper, just using the free "basic" access to the resources, with publicly accessible tools and without any tuning and some common sense to match the obvious inflexion points on the graphs with the relevant corresponding historical data, one can immediately observe how the real world resonates with specific subjects at certain times. This is encouraging as a starting point for future and more focused studies meant to understand and even predict social, political and electoral trends.

\section{References}

- BING PAN, YANG YANG (2017) Forecasting Destination Weekly Hotel Occupancy with Big Data, in: Journal of Travel Research, 56(7), September 2017, https://www.researchgate.net/publication/306281637_Forecasting_Destination_Weekly_ Hotel_Occupancy_with_Big_Data [Accessed 09/2017].

- CARNEIRO, H. A./ MYLONAKIS, E. (2009) Google Trends: A Web-Based Tool for Real-Time Surveillance of Disease Outbreaks, in: Clinical Infectious Diseases. Volume 49, Issue 10, 15 November 2009, pp. 1557-1564, https://doi.org/10.1086/630200 [Accessed 09/2017]

- CARRIÈRE-SWALlOW, Y. /LABBÉ, F. (2013) Nowcasting with Google Trends in an emerging market, in: Journal of Forecasting. 32(588) July 2013, https://www.researchgate.net/publication/265252591_Forecasting_Chinese_tourist_volu me_with_search_engine_data [Accessed 09/2017].

- CHOI, H./VARIAN, H. (2012) Predicting the Present with Google Trends. The Economic Record, Vol. 88, pp. 2-9, http://dx.doi.org/10.1111/j.1475-4932.2012.00809.x [Accessed 09/2017]

- Europa.eu (2005) Treaty establishing a Constitution for Europe, [Online] Europa.eu, https://europa.eu/european- 
union/sites/europaeu/files/docs/body/treaty_establishing_a_constitution_for_europe_en.p df [Accessed 08/2017]

- Europa.eu (2017) The history of the European Union - 2004, [Online] Europa.eu, https://europa.eu/european-union/about-eu/history/2000-2009/2004_en [Accessed 08/2017]

- Gartner.com (2017) The Gartner IT Glossary, [Online] Gartner.com, http://www.gartner.com/it-glossary/ [Accessed 08/2017]

- GINSBERG J./ MOHEBBI M.H./ PATEL R.S./ BRAMMER L./ SMOLINSKI M.S./ BRILLIANT L. (2009) Detecting influenza epidemics using search engine query data, in: Nature, 2009, vol. 457, pp. 1012-1014.

- Google.com (2017) How Search algorithms work. [Online] Google.com, https://www.google.com/search/howsearchworks/algorithms/ [Accessed 09/2017]

- LI, Xinyuan (2016) Nowcasting with Big Data: is Google useful in the Presence of other Information? London Business School mimeo, https://editorialexpress.com/cgibin/conference/download.cgi?db_name=IAAE2016\&paper_id=215 [Accessed 09/2017]

- PREIS T./ MOAT, H. S./ STANLEY, H.E. (2013) Quantifying Trading Behavior in Financial Markets Using Google Trends, in: Scientific Reports. 3, Art. No: 1684 https://www.nature.com/articles/srep01684.pdf [Accessed 09/2017]

- SEIFTER A./ SCHWARZWALDER A./ GEIS K./ AUCOTT J. (2010) The utility of "Google Trends" for epidemiological research: Lyme disease as an example, in: Geospatial Health. 4(2), pp. 135-137.

- VARIAN, H. R./ CHOI, H. (2009) Predicting the Present with Google Trends, Google Research Blog http://googleresearch.blogspot.com/2009/04/predicting-present-withgoogle-trends.html, http://dx.doi.org/10.2139/ssrn.1659302 [Accessed 09/2017]

- YANG, X./ BING P./ EVANS, J. A./ BENFU L. V. (2015) Forecasting Chinese tourist volume with search engine data, in: Tourism Management. 46, pp. 386-397. https://www.researchgate.net/publication/265252591_Forecasting_Chinese_tourist_volu me_with_search_engine_data [Accessed 09/2017] 


\title{
TOWARDS A MORE ACCOUNTABLE EU - MISSION POSSIBLE?
}

\author{
Gergana RADOYKOVA
}

Assistant Professor, $\mathrm{PhD}$

Political Science Department, Faculty of Philosophy, Sofia University "St. Kliment Ohridski”

geri_radoykova@yahoo.com

\section{DOI:10.24193/OJMNE.2017.23.06}

\begin{abstract}
The European Union's uniqueness is very much related to its ever-changing nature. Now, when the European project is facing one of the biggest crisis in its history, it is inevitable that some changes will and shall occur. We are at a crucial phase of the development of the European Union. At a time of multiple global, economic, environmental and societal transformations and challenges European citizens expect the European Union to make a concrete difference in addressing the biggest of them.

The author believes that the main objective shall be bringing back the awareness and trust of the European citizens in the European project, in improving the accountability mechanisms of the European institutions, which are the key legitimizing factor of the EU decision-making process. The European Parliament, together with the national parliaments shall play a central role in this process.
\end{abstract}

Keywords: European Union, European Parliament, citizens' participation, awareness, accountability.

"A body of men, holding themselves accountable to nobody, ought not to be trusted by anybody" Thomas Paine, “The Rights of Man” (1791)

Over the past 60 years the European community and later the European Union has been in a process of constant development and transformation. Starting with the European Coal and Steel Community in the late 50's it is continuously growing - in geographic terms, but most importantly - in the amount of competencies and influence in different policy areas 
- from the single market and monetary union to immigration, judicial and policy cooperation, including common foreign policy.

Needless to say, expanding the powers of the EU led to growing of the expectations of the citizens of the Union. It has been an old tradition to hold national governments responsible for bad economic conditions - now the EU is often shouldering most of the blame when things go not as expected.

The most important thing, however, is that the relation EU-citizens is damaged. The European Union is currently facing one of the most serious crises in its existence, which can be probably described better with the sentence "Brussels, we do not trust you". Still, citizens' participation is remarkably important for each democratic system, so as for its democratic legitimacy as its cornerstone.

The trust of citizens in the democratic institutions has been fading. One of the most obvious effects is the ever decreasing rate of the voting attendance of the European citizens. It endangers the legitimacy of the European Union as its political institutions are being questioned and doubted, and the national governments are often under the pressure of international bodies.

The reaction of the EU to the economic and financial crisis, the migration crisis and the terrorist threat financial crisis, shows it is a must for the EU to prove being capable to learn from its mistakes and to move forward to an inclusive participatory democracy - where the voice of the people is not just heard but also considered during the decision-making process.

\section{The salience of democratic accountability}

Here, in my opinion, the question of democratic accountability is central. To what extent are citizens capable of holding the public institutions to account for their actions? The answer is quite simple: the most important thing is to exist a "point of intersection" between the level of political decision-making by the actor (politicians) and the level on which the forum (citizens) can demand accountability from those whom they have previously empowered through elections (Curtin, 2010). This is quite a difficult task in a multilevel system of governance, such as the EU. A crucial question is whether citizens can understand 
who is responsible and assign responsibility and accountability accordingly (Allerkamp, 2010). The capacity and willingness of citizens to take active part in the political debate and the decision-making process, and to urge the politicians to give account for their actions, is undoubtedly the hallmark of good governance and real democracy (Hood, 2012).

When we elaborate on the important topic of accountability in politics, it is wise to start with an attempt for definition. What does accountability mean and stand for? How can it be measured? Why do we bother about accountability in politics at all?

Accountability is considered and generally accepted to be a "golden concept", which is supposed to be a key component and one of most important features of each democratic governance. That means that in most of the cases accountability has mainly positive connotations. Why? There could be at least two reasons. First and foremost, public institutions are obliged to explain the decisions they make on behalf of the electorate and also to give clear account about the way in which they spend public money. Second, the adjective "accountable" is often associated with transparency, reliability and truthfulness.

In reality accountability is a very broad concept, which serves as an umbrella for quite different concepts. There is no doubt, however, that accountability is the key legitimizing factor of the public institutions.

We choose to follow the definition of Mark Bovens and Deirdre Curtin, according to which accountability is a social relationship between an actor and a forum, in which the actor has an obligation to explain and to justify his or her conduct, the forum can pose questions, and the actor may face certain consequences (Bovens, Curtin, Har, 2011). Analyzing accountability from that perspective gives the opportunity to study the whole chain of interactions between citizens (as the forum) and public institutions (as the actor), as well as the positive and negative aspects of accountability arrangements.

Each accountability relationship should consist of at least three main elements. First of all comes information. It is very important that the actor regularly informs the forum about his conduct and political decisions, as well as about concrete procedures and accomplished results. But simply informing the forum (the citizens) does not only consist of providing detailed data to the general public. It also includes the obligation for the forum to explain and justify its conduct. 
The second face is the debate. After receiving the information, the forum should have the possibility to ask any question, concerning this information and the legitimacy of the decisions. The forum has the obligation to give an answer to all the questions. That is why the term "accountability" is often equalized with "answerability", but the latter is actually one of the "ingredients" of accountability.

Third and most important, the forum can pass judgement on the justification of the actor. The judgement could be positive, of approval, or negative. And if there is enough evidence of misconduct the forum may face sanctions. It is the possibility of sanctions that makes the most important element of an accountability relationship.

There are different opinions among researchers, however, whether sanctions are actually an element of accountability. The term "sanction" itself is quite formal and legal and has quite negative connotations. It excludes forums of accountability who do not have the authority to formally impose sanctions but their opinion still matters a lot. That is the reason why in this context we prefer to remain neutral by saying that the actor may face consequences for its behavior, rather than sanctions.

There is a common practice to use the term "transparency" instead of "accountability". The above mentioned definition, however, shows us that transparency is not enough to cover the constitutive elements of the accountability relationship. Transparent government, freedom of speech and information are just important prerequisites for accountability, especially when it comes to providing information. Transparency, however, lacks something very essential - it does not involve scrutiny and monitoring from the forum. While accountability implies mainly the obligation for the actor to justify political decisions and actions, transparency stands for the type of behavior that makes the actions of the forum visible for the observers (Hood, 2010).

It is also important to distinguish accountability from participation, openness and responsiveness. It often happens, especially in the official documents at EU level that accountability is related to issues of representative deliberation. Here a very important detail seems to be forgotten - the actors (politicians) are to give account to the forum (citizens) after they act, so the essence of accountability is retrospective. Responsiveness, openness and deliberation are very important for enhancing legitimacy, but they do not form accountability 
and are more likely to be a prerequisite for it. What is missing is the element of sanction and consequences, good or bad, for the actor.

We have to admit, however, that the difference between retrospective accounting and active policy making is quite thin at times. It makes sense that the actors should give account for their decisions and for their participation in the decision-making. Accountability is not only about ex post monitoring and evaluation, it also about prevention. Political decisions and the behavior of the actors should be adjusted and bettered through accountability.

Accountability is also often identified with control. Some researchers and politicians would even put a sign of equality between them. What seems to be forgotten here is the following definition: "An agent is accountable to a principal if the principal can exercise control over the agent" (Lupia, 2003). So accountability is a form of control but not all forms of control are actually mechanisms for accountability.

And last, but not least - there is a difference between accountability and responsibility. Responsibility as a virtue demands an answer of the question "What is right to be done?" It also implies trust, prudence, stability and erudition. That is why responsibility is not equal to accountability, it creates and strengthens accountability.

If we choose to follow the famous Lincoln definition for "government of the people, by the people for the people", we should conclude that legitimacy has two faces. Input legitimacy stands for government by the people, while output legitimacy is based on the concrete results and is about government for the people. When we discuss and evaluate the results, we can clearly observe the importance of accountability for legitimizing the work of the public institutions.

\section{Representative vs. direct democracy in the EU}

If we look at the institutional structure of the European Union, we will see that it is based on representative democracy, putting more emphasis on participation in the last decade. The European Union emphasizes and encourages citizen participation and is constantly trying to set up a proper legal framework in order to strengthen its democratic legitimacy. The Treaty of Lisbon sets that: 
1. The institutions shall, by appropriate means, give citizens and representative associations the opportunity to make known and publicly exchange their views in all areas of Union action.

2. The institutions shall maintain an open, transparent and regular dialogue with representative associations and civil society (TEU, 2009).

So this is the legal basis for bringing the European Union closer to its citizens, for making it more transparent, understandable, and "digestible" for the citizens.

An example of a typology based on citizen involvement is the classic model of Arnstein. According to Arnstein can be demonstrated by a ladder - its rungs represent the different levels of participation. She defines eight rungs starting from manipulation through consultation to citizen control, concluding that citizen participation is citizen power (Arnstein, 1969).

The responsibility to decide is delivered over to the elected individuals, who undertake the responsibility this representative role. It is a system of indirect citizens' control, where the people express their opinion, influence the decision-making process through their elected representatives who exercise political authority. In the case of the European Union it means an orientation towards providing a more significant role for the European Parliament and involving the national parliaments of the member states in the decision-making process.

The European Union has developed a new form of interaction between its citizens and the institutions of the Union. One of the most important proposal was the establishment of the European Citizens' Initiative in 2012, which aims to urge citizens' involvement in the shaping of EU policies. Unfortunately, 5 years from the launching of ECI, it proved to be a disappointment, rather than success.

According to the European Commission's Guide (European Commission, 2011) the European Citizens' Initiative is a big step towards a wider involvement of the European citizens in forming the EU's legislative system. It enables 1 million European citizens (from at least seven countries of the EU) to propose a legal act in areas which are within the competence of the European Commission The initiative has one year to collect the necessary signatures, in the next phase the Commission examines and decides how to act on it. 
In my opinion the initiative was a good idea as a whole, but in practice it brings up some difficulties. Compared to the total population of the European Union ( 500 million) the needed minimum number of signatures for starting an initiative makes only its $0,2 \%$. So it might turn into a good opportunity for the lobbyists who can use it to their advantage. However the main aim of the ECI is to give a voice to the ordinary citizens, not to certain interest groups, good in persuasion. If the process is not simplified and not wellcommunicated, then citizens will not take advantage of the option. Besides, the European Union should provide a fast and satisfactory feedback about the outcome of the actual initiatives in order to maintain the connection with its citizens. The ECI should be simplified and strengthened so it can be a useful tool for citizens' awareness and participation.

\section{Advantages and risks of citizen participation}

According to Sutton Trust findings (Sutton Trust, 2006) increasing the number of people who are actively engaged in democratic process is priority for the efficient functioning of the EU. Participation gives the citizens an opportunity to express their desires, aims, so the decisions can be more incisive, and also the accidental conflicts between different groups can be prevented. Moreover, local people can improve their skills, develop their abilities, and their willingness to consensus and to achieve long-lasting solutions to any local problem. In addition, participation increases social cohesion between local people, as it increases the level of trust and the sense of belonging to the territory.

Sutton Trust research also reveals the disadvantageous side of citizens' participation. Creating awareness and involving citizens in decision-making leads and aims toward equality. If the number participants is narrow, lacking an efficient selection method, the democratic control is not actually fulfilled. Besides this, participation in the last year has proved to be a strong weapon for populists all over the European Union. It can also be a very time-consuming for achieving consensus. Citizen participation is also criticized as naive, unrealistic, lacking broad representation, and that citizens are primarily following their personal interests, and not the public good (Callahan, 2007).

Citizens need to feel motivated to urge to participate in the decision-making process if they see the positive benefits in their everyday life from doing so. People also feel motivated 
when they have some aspect of their life or welfare threatened and when they have a better understanding of a political issue or situation.

Back in 2001 the European Commission presented a White Paper on Good Governance proposing "openness" and "participation" by involving the civil society (European Commission, 2011). Still The White Paper focused mostly on involvement of specific interest groups, civil organizations, and not on the ordinary citizens.

The year of 2013 was proclaimed as the "European Year of Citizens", aiming to strengthen "active citizenship", and to involve the ordinary citizens in dialogues, and in the work and policy-making of the EU institutions. Still what truly happens is that the EU stands for creating a direct relationship with its citizens but during circumvents the governments of its member-states, instead of collaborating with them.

In March 2017, the European Commission launched a White Paper on the Future of Europe. Discussions about the EU's 'democratic deficit' have been going on for decades, so the issues the White Paper brings up are not new. However, for the first time there seems to be a definite recognition of the need for change. The Commission's discussion paper is remarkably candid about widespread public distrust of Brussels, stating for example that “citizens' trust in the EU has decreased in line with that for national authorities" (White Paper on the Future of Europe, 2017). Around a third of citizens trust the EU today, when about half of Europeans did so ten years ago. Overcoming this mistrust issue will not be easy, since: "Communities are not always aware that their farm nearby, their transport network or universities are partly funded by the EU".

The White Paper emphasizes the importance of facing expectations as being critical for future success of the European project. Where the Commission builds up expectations for economic growth and cross-border harmony driven from Brussels, it truly and inevitably makes itself vulnerable to attacks. When suggesting faster and stronger integration as one option (the fifth and final), the Commission notes there is the risk of alienating parts of society which feel that the EU lacks legitimacy or has taken too much power away from national authorities. On the other hand, the Commission states firmly that going back to the single market alone is not a good (second) option, etc. 
Problems originate from the citizens who are uninformed about their rights and possibilities what they possess by being citizens of the EU. In my opinion is important to fill the term "European citizenship" a real content besides its symbolic interpretation by informing the citizens with the help of mass media.

Moreover, there are various legal tools for citizens to petition or make complaints against the decisions of the EU, but these opportunities are not used very often - often for red tape considerations. The EU are complex and time-consuming nature of these legal tools, and also the ignorance of citizens about their rights.

The EU creates all the tools for the citizens' involvement, but still it may somehow try hinder this participation. Public officials may state that citizens are incompetent, while citizens, on the other hand blame the officials and institutions for not being invited to truly participate in the process - proving the saying that "ninety percent of politics is deciding whom to blame (Greenfield, 1996).

If citizens are not involved in the decision-making process from its beginning, they are usually less supportive. Citizens should be encouraged by feedback of the completed projects. People as a whole are more dedicated to participate in any initiative if they see it as their own and experience the betterment in the life of their own locality. The civil society should be strengthened to support democracy, in order to stop the declining trust of citizens in their politicians. The European Union and the members-states should encourage more voluntary activities and social connectedness which would represent "happening of participatory democracy".

The citizens of post-communist member-states, such as Bulgaria for example, show a diverse willingness to participate in the decision-making process both on European and national level.

\section{The role of media and information}

In the very complex system of the EU information matters a lot. Media has become a very powerful communication channel which can unfortunately be used as a tool to manipulate the masses. Media can prove to be very influential, convincing messages for the people, who are many times unaware of the fact that they are influenced. The European 
Union often uses the help of the media to inform citizens about its achievements, initiative. The shift towards a participatory democracy and the freedom of speech involves the risks of demagogic and populist interventions which must be controlled in order to preserve its legal pursuit. The new possibilities given by modern technologies should be utilized, but wisely.

People who are more politically aware are also able to assign responsibility to the EU correctly. It is interesting that people who read papers with a lot of EU coverage are prove to be more competent than those who rely on television coverage - it is very often for television to simply prime the citizens to think more about the EU (Hobolt, Tilley, 2014).

\section{Conclusion}

In the EU, there are two contradictory trends which are simultaneously presented: globalization and centralization. While certain decisions are moved from national to EU level taking away some national sovereignty, on the other hand the principle of "subsidiarity" is also emphasized, which refers to solving problems on lower levels and supporting community activity. The Union, therefore, on one hand enhances citizen participation by using deliberative methods to involve stakeholder, but on the other hand widens the gap between its citizens and the policy-makers.

At the time of a legitimacy crisis of the EU, much attention should be paid on fostering a comprehensively efficient citizen participation. It means creating a platform which is transparent and easily available for ordinary citizens or for civil organizations. Through this they can visibly participate in the public debates and express their opinion.

After looking over the different factors and influences which pull back the establishment of a legally operating participatory system, the following observations can be specified:

- Civil participation and awareness is crucial for the legitimacy of the European Union

- The legal basis for citizen participation is adequate, the obstacles mainly appear in putting them into practice

- A feedback is needed about the outcome of any initiative on EU level, that implies citizen participation

- A two-way communication is needed between the citizens and the authorities 
- Media should be utilized in a fair way by the EU - to inform citizens about the results and the possibilities and not to manipulate them

Citizens should start to care not only about what the EU and its institutions can do for them and their countries, but also what the same EU institutions can do for the European project as a whole. As the President of the European Council stated recently - "United we stand, divided we fall” (Tusk, 2017).

\section{Bibliography}

- ALlERKAMP, D. (2010). Who Sets the Agenda? - How the European Council and the Team Presidencies Are Undermining the Commission's Prerogative - ECPR SG EU Porto, Portugal, http://www.jhubc.it/ecpr-porto/virtualpaperroom/159.pdf, [Accessed 03/09/2017].

- ARNSTEIN, S. (1969). A Ladder of Citizen Participation. In: AIP, Vol. 35, No. 4, July 1969, pp. 216-222, http://www.tandfonline.com/doi/abs/10.1080/01944366908977225, [Accessed 13/09/2017].

- BOVEns, M./ CURTIN, D./ HART, P. (eds.) (2010). The Real World of EU Accountability. What Deficit? Oxford: Oxford University Press.

- BOVEnS, M./ SCHILlERMANS, T./ HART, P. (2008) Does Public Accountability Work: An Assessment Tool? In: Public Administration 86/1, pp. 225-242, http://academic.udayton.edu/RichardGhere/org\%20theory\%202009/major\%20readings/B ovens\%20Schill\%20performance.pdf. [Accessed 08/09/2017].

- CALlaHAN, W. A. (2007) Future Imperfect: The European Union's Encounter with China (and the United States). In: Journal of Strategic Studies, Vol. (4-5), pp. 777-807 (ON), $\quad$ https://rd.springer.com/article/10.1007/s12140-009-9104-1?no-access=true. [Accessed 13/09/2017].

- CURTIN, D. (2009) Executive Power of the European Union. Law. Practices and the Living Constitution. Oxford: Oxford University Press. 
- CURTIN, D./ MAIR, P./ PAPADOPOULOS, Y. (2012) Accountability and European Governance. Routledge, USA and Canada: West European Politics Series.

- CURTIN, D./ MEIJER, A. (2006) “Does Transparency Strengthen Legitimacy? A Critical Analysis of European Union Policy Documents”. In: Information Polity, 11:2, pp. 109-22, https://papers.ssrn.com/sol3/papers.cfm?abstract_id=1434862, [Accessed 30/09/2017].

- FOLlESDAL, A./ HIX, S. (2006) "Why There Is a Democratic Deficit in the EU: A Response to Majone and Moravcsik”. In: Journal of Common Market Studies, 44:3, pp. 530 - 560, https://papers.ssrn.com/sol3/papers.cfm?abstract_id=1682094, [Accessed $15 / 09 / 2017]$.

- HOBOLT, S./ TILLEY J. (2014) Blaming Europe? Responsibility without Accountability in the European Union. Oxford: Oxford University Press.

- KARLSSON, C. (2009) Holding Treaty Reformers Accountable: Any Progress? In: GUSTAVSSON, S./ KARLSSON, C./ PERSSON, T (eds.) The Illusion of Accountability in the European Union. London: Routledge, pp. 67-82.

- LUPIA, A. (2003) Delegation and its Perils. In: STROM, K./ MULLER, W./ BERGMAN, T. (eds). Delegation and Accountability in Parliamentary Democracies. Oxford: Oxford University Press.

- MORAVCSIK, A. (2002) In Defence of the Democratic Deficit: Reassessing Legitimacy in the European Union. In: Journal of Common Market Studies, 40/4, pp. 603-624, Available at: https://www.princeton.edu/ amoravcs/library/deficit.pdf, [Accessed 13/09/2017].

- SETAlA, M./ SCHILlER, T. (2012) Citizens' Initiatives in Europe, Palgrave, Macmillan.

\section{Official documents}

- Treaty of Lisbon amending the Treaty on European Union and the Treaty establishing the European Community, signed at Lisbon, 13 December 2007, Official Journal of the European Union, 2007/C 306/01, http://eur-lex.europa.eu/legalcontent/BG/TXT/?uri=CELEX:12007L/TXT, [Accessed 12/09/2017]. 
- Regulation (EU) No 211/2011 of the European Parliament and of the Council of 16 February 2011 on the citizens' initiative (Consolidated version 28/07/2015), http://eurlex.europa.eu/legal-content/EN/TXT/PDF/?uri=CELEX:02011R0211-

20150728\&from=EN. [Accessed 08/09/2017].

- EUROPEAN COMMISSION (2001), White Paper on Good Governance, http://eurlex.europa.eu/legal-content/EN/TXT/?uri=LEGISSUM:110109, [Accessed 01/09/2017].

- EUROPEAN COMMISSION, (2011) Guide to the European Citizens' Initiative. Available at: https://publications.europa.eu/en/publication-detail/-/publication/ac66340b5355-4df6-9095-93ac91dadd18/language-bg, [Accessed 07/10/2017].

- EUROPEAN COMMISSION (2017), White Paper on the Future of Europe - Reflections and Scenarios for the EU27 by 2025, https://ec.europa.eu/commission/sites/betapolitical/files/white_paper_on the future_of_europe_en.pdf. [Accessed 21/09/2017].

- EUROPEAN COUNCIL (2017), Letter by President Donald Tusk to the 27 EU heads of state or government on the future of the EU before the Malta summit, http://www.consilium.europa.eu/en/press/press-releases/2017/01/31-tusk-letter-futureeurope/. [Accessed 19/09/2017]. 